\title{
2. SEDIMENTOLOGICAL AND GEOCHEMICAL CHARACTERISTICS OF LEG 129 SILICEOUS DEPOSITS ${ }^{1}$
}

\author{
S. M. Karl, ${ }^{2}$ G. A. Wandless, ${ }^{3}$ and A. M. Karpoff ${ }^{4}$
}

\begin{abstract}
Siliceous deposits drilled on Ocean Drilling Program Leg 129 accumulated within a few degrees of the equator during the Jurassic through early Tertiary, as constrained by paleomagnetic data. During the Jurassic and Early Cretaceous, radiolarian ooze, mixed with a minor amount of pelagic clay, was deposited near the equator, and overall accumulation rates were moderate to low. At a smaller scale, in more detail, periods of relatively higher accumulation rates alternated with periods of very low accumulation rates. Higher rates are represented by radiolarite and limestone; lower rates are represented by radiolarian claystone. Our limited data from Leg 129 suggests that accumulation of biogenic deposits was not symmetrical about the equator or consistent over time. In the Jurassic, sedimentation was siliceous; in the Cretaceous there was significant calcareous deposition; in the Tertiary claystone indicates significantly lower accumulation rates at least the northern part of the equatorial zone. Accumulation rates for Leg 129 deposits in the Cretaceous were higher in the southern part of the equatorial zone than in the northern part, and the southern side of this high productivity zone extended to approximately $15^{\circ} \mathrm{S}$, while the northern side extended only to about $5^{\circ} \mathrm{N}$.

Accumulation rates are influenced by relative contributions from various sediment sources. Several elements and element ratios are useful for discriminating sedimentary sources for the equatorial depositional environments. Silica partitioning calculations indicate that silica is dominantly of biogenic origin, with a detrital component in the volcaniclastic turbidite units, and a small hydrothermal component in the basal sediments on spreading ridge basement of Jurassic age at Site 801. Iron in Leg 129 sediments is dominantly of detrital origin, highest in the volcaniclastic units, with a minor hydrothermal component in the basal sediments at Site 801. Manganese concentrations are highest in the units with the lowest accumulation rates. Fe/Mn ratios are $>3$ in all units, indicating negligible hydrothermal influence. Magnesium and aluminum concentrations are highest in the volcaniclastic units and in the basal sediments at Site 801. Phosphorous is very low in abundance and may be detrital, derived from fish parts. Boron is virtually absent, as is typical of deep-water deposits. Rare earth element concentrations are slightly higher in the volcaniclastic deposits, suggesting a detrital source, and lower in the rest of the lithologic units. Rare earth element abundances are also low relative to "average shale." Rare earth element patterns indicate all samples are light rare earth element enriched. Siliceous deposits in the volcaniclastic units have patterns which lack a cerium anomaly, suggesting some input of rare earth elements from a detrital source; most other units have a distinct negative $\mathrm{Ce}$ anomaly similar to seawater, suggesting a seawater source, through adsorption either onto biogenic tests or incorporation into authigenic minerals for Ce in these units.

$\mathrm{The} \mathrm{Al} /(\mathrm{Al}+\mathrm{Fe}+\mathrm{Mn})$ ratio indicates that there is some detrital component in all the units sampled. This ratio plotted against $\mathrm{Fe} / \mathrm{Ti}$ shows that all samples plot near the detrital and basalt end-members, except for the basal samples from Site 801, which show a clear trend toward the hydrothermal end-member. The results of these plots and the association of high Fe with high $\mathrm{Mg}$ and $\mathrm{Al}$ indicate the detrital component is dominantly volcaniclastic, but the presence of potassium in some samples suggests some terrigenous material may also be present, most likely in the form of eolian clay. On Al-Fe-Mn ternary plots, samples from all three sites show a trend from biogenic ooze at the top of the section downhole to oceanic basalt. On Si-Fe-Mn ternary plots, the samples from all three sites fall on a trend between equatorial mid-ocean spreading ridges and north Pacific red clay. Copper-barium ratios show units that have low accumulation rates plot in the authigenic field, and radiolarite and limestone samples that have high accumulation rates fall in the biogenic field.
\end{abstract}

\section{INTRODUCTION}

Siliceous deposits are enigmatic indicators of high-productivity sedimentary environments. They accumulate in several marine environments, which are generally distinguished with the aid of lithologies associated with the siliceous deposits. Sedimentary and geochemical characteristics of siliceous deposits are used to discriminate between depositional environments and define paleoceanographic conditions for these deposits.

On Leg 129, several types of siliceous deposits were cored. The results of detailed sedimentological studies are presented in Ogg et al. (this volume), and diagenetic studies are presented in Behl and Smith (this volume). The known environmental conditions include

\footnotetext{
${ }^{1}$ Larson, R. L., Lancelot, Y., et al., 1992. Proc. ODP, Sci. Results, 129: College Station, TX (Ocean Drilling Program).

${ }^{2}$ U.S. Geological Survey, Branch of Alaskan Geology, 4200 University Drive, Anchorage, AK 99508-4667, U.S.A.

${ }^{3}$ U.S. Geological Survey, National Center, MS 990, 12201 Sunrise Valley Dr., Reston, VA 22092, U.S.A.

${ }^{4}$ Centre de Géochimie de la Surface-CNRS, Institut de Géologie, 1 rue Blessig, 67084 Strasbourg Cedex. France,
}

initial deposition on a mid-ocean spreading ridge at moderate accumulation rates averaging $700 \mathrm{~g} / \mathrm{cm}^{2} / \mathrm{m}$.y. (Ogg et al., this volume), near the equator in the middle of the Mesozoic Pacific Ocean (Lancelot, Larson, et al., 1990). The sites drilled during Leg 129 initially migrated southward from the equator, and subsequently moved northward across the equator and into the north Pacific basin (Lancelot, Larson, et al., 1990). Accumulation rates for siliceous deposits in excess of $1000 \mathrm{~g} / \mathrm{cm}^{2} / \mathrm{m}$.y. characterize these equatorial crossings (Ogg et al., this volume). Although we know the general tectonic, paleoceanographic, and biologic setting of these siliceous deposits, sedimentary, diagenetic, and chemical characteristics can help us define these environments more precisely and gain insights into circulation patterns and productivity cycles in the Mesozoic Pacific Ocean.

In this paper we focus only on the siliceous deposits. Our purpose is to examine changes in siliceous deposition at Leg 129 sites through time, and to identify significant factors affecting siliceous deposition. We do not address general sedimentation at these sites because abundant turbidite deposition masks other paleoceanographic processes, and because poor recovery limits our ability to assess the representativeness and relative proportions of lithologies cored at Leg 129 sites. 


\section{TERMINOLOGY}

The classification of siliceous sediments and rocks in this paper follows the definitions provided in the Initial Reports for Leg 129 (Lancelot, Larson, et al., 1990). The term biogenic is applied when $30 \%$ or more of the sediment is carbonate or silica from a biogenic source. Pelagic biogenic ooze consists of $60 \%$ or more organisms. Transitional pelagic ooze contains $30 \%$ to $60 \%$ organisms, and at least $40 \%$ silt or clay. Pelagic clay has less than $30 \%$ organisms.

There are several types of pelagic clay. Eolian pelagic clay contains detrital clay minerals and quartz crystals. Authigenic pelagic clay contains authigenic clay minerals, zeolites, iron oxides, and ferromanganese micronodules. Volcanogenic pelagic clay contains glass, mafic minerals, feldspar, volcanic rock fragments, palagonite, and clay minerals derived from alteration of volcanic material. Pelagic clay in general may also contain fish parts and cosmic particles. Sediment samples were analyzed for clay mineralogy by X-ray diffraction (XRD) aboard ship and on the microprobe at the University of Strasbourg, France. The preliminary interpretations used for this study did not discriminate species of smectite; Karpoff (this volume) identified dioctahedral smectite $(\mathrm{d}\{060\}=1.50 \AA)$, possible illite, and interlayered illite-smectite.

The siliceous deposits studied include biogenic siliceous material in various stages of preservation and recrystallization. Terms for silica phases of samples used in this study are "field terms" based on properties observed in core samples. Silica phases were not analyzed for this study, but some samples correspond to samples analyzed by Behl and Smith (this volume). The term chert is used for siliceous deposits recrystallized to opal C/T (cristobalite/tridymite) and cryptocrystalline, microcrystalline, or chalcedonic quartz. Chert has a glassy to waxy luster, smooth conchoidal fracture, and a hardness of 6.3-7.0. Porcellanite has the same silica mineralogy plus more than $10 \%$ clay. Porcellanite has a dull luster, matte surface, blocky fracture, and a hardness of 4.0-5.5. Radiolarite has less than $10 \%$ clay, a rough, sandy texture, granular fracture, and is soft to friable. Modifiers to these terms are used to reflect the presence of components in excess of $25 \%$. A clayey radiolarite has more than $25 \%$ clay. A "radiolarite with clay" contains $10 \%$ to $25 \%$ clay.

Accumulation rates were calculated using fossil age determinations and stratigraphic thickness. Original rates of deposition or sedimentation are not known, because volume changes resulting from diagenetic processes have not been quantitatively determined. In this study, high or low sedimentation rates are thus relative terms only. Accumulation rates less than $3 \mathrm{~m} / \mathrm{m}$.y. are considered low. Accumulation rates in excess of $10 \mathrm{~m} / \mathrm{m}$.y. are considered high. Because the ocean is greatly undersaturated with respect to silica and dissolution takes place at the sediment-water interface, it is generally inferred that low accumulation rates reflect low sedimentation rates, and the converse is also true.

\section{SAMPLE DESCRIPTION}

\section{Site 800}

Unit I brown pelagic clay from the top of the sequence was not sampled for this study.

Unit II (Fig. 1) is late Campanian to Turonian in age, and consists of $40 \mathrm{~m}$ of porcellanite and radiolarian chert (Lancelot, Larson, et al., 1990; Behl and Smith, this volume). Both phases are brown. The chert is patchy, cuts across sedimentary laminations, and increases in abundance downsection. All samples studied from this unit (Table 1) are composed of mottled brown and pale brown chert; the sample from Core 129-800A-7R has black Mn-oxide coatings on the surface of some bedding laminations.

Unit III is Turonian to early Albian in age and consists of $150 \mathrm{~m}$ of olive gray to gray radiolarian chert and finely laminated siliceous limestone, with subordinate nannofossil chalk (Lancelot, Larson, et al., 1990). The silicification of the chalk and limestone is patchy and discontinuous. Locally laminations are disrupted by burrows, and some laminations are deformed. The chert contains up to $45 \%$ radiolarians, many of which are filled with opal $\mathrm{C} / \mathrm{T}$, chalcedony, and rare barite crystals. The limestone contains up to $25 \%$ radiolarians as well as foraminifers and locally abundant nannofossils. Limestone increases downsection. Replacement chert in the limestone forms beddingparallel laminations and nodules with bedding-discordant, cuspate, convex-outward silicification fronts that grade from chert to calcareous porcellanite, which in turn grades to the host limestone. From Core 129-800A-22R downward, volcanic clasts were observed and smectite was identified by shipboard XRD analyses (Lancelot, Larson, et al., 1990). In Core 129-800A-23R clinoptilolite and smectite were identified in clayey radiolarite. These minerals are characteristic of the underlying volcaniclastic turbidite unit and indicate a gradational transition to that unit.

Samples from Unit III are composed of chert, radiolarian porcellanite, and porcelaneous radiolarite. Most samples are pinkish to brownish green or gray, indicating transitional redox conditions. Samples from Cores $129-800 \mathrm{~A}-13 \mathrm{R}$ and $-24 \mathrm{R}$ contain black manganiferous streaks.

Unit IV is Aptian in age and consists of $221 \mathrm{~m}$ of volcaniclastic sand-silt-clay turbidites with intervals of pelagic radiolarian claystone. The turbidites are predominantly green, and the radiolarian claystone intervals are typically brown. Turbidite sandstone is composed mainly of volcanic detritus, with minor, variable amounts of calcareous shallow-water biogenic debris or calcareous cement. Detrital claystone within turbidite beds contains volcanic glass, plagioclase, pyroxene, iron oxides, smectites, montmorillonite, clinoptilolite, up to $25 \%$ radiolarians and up to $15 \%$ nannofossils. The pelagic claystone, calcareous claystone, radiolarian claystone, and clayey radiolarite between turbidite beds are finely laminated and contain up to $50 \%$ radiolarians, with subordinate volcanic glass, clay minerals, iron oxides, and rare plagioclase, pyroxene and volcanic rock fragments. Fractures in Core $129-800 \mathrm{~A}-38 \mathrm{R}$ are coated with Mn-oxide dendrites.

Samples studied from Unit IV are all from pelagic intervals except for Samples 129-800A-26R-1, 135-139 cm, 129-800A-27R-1, 61-64 $\mathrm{cm}, 129-800 \mathrm{~A}-41 \mathrm{R}-1,87-93 \mathrm{~cm}$, and 129-800A-44R-1, 92-94 cm, which are claystones from the tops of turbidites sampled for comparative purposes.

Unit $\mathrm{V}$ is Barremian to Berriasian and consists of $48.5 \mathrm{~m}$ of massive to microlaminated clayey radiolarite and radiolarian claystone (Lancelot, Larson, et al., 1990). The unit is dominantly red or brown, with rare green reduced zones. The radiolarite alternates with claystone on a centimeter scale but radiolarite is the dominant lithology ( $60 \%$ to $80 \%$ of each core). Radiolarite layers contain up to $85 \%$ radiolarians. Some layers are bioturbated. Shipboard XRD analyses indicate the presence of smectite, zeolites, and feldspar. Manganese oxides occur as lenses, as laminations, as accumulations around burrows or along redox fronts, as micronodules, as radiolarian fillings, and as fracture coatings. Fractures are also commonly filled with silica. Samples studied from this unit are all from radiolarite layers except Sample 129-800A-52R-1, 16-20 cm, which is a claystone with Mn-oxide streaks.

Unit VI is Berriasian(?) in age and consists dominantly of dolerite sills with minor amounts of recrystallized siliceous sediment trapped between sills (Lancelot, Larson, et al., 1990). The sample from the lowest sedimentary rock cored at Site 800 is from a chert lens between dolerite sills. This chert is brown, red or bleached pink, and microlaminated similar to the radiolarite of overlying Unit V. The sample studied is massive brown chert with approximately $5 \%$ ghosts of radiolarians and $1 \%$ opaque minerals. Iron staining is patchy in thin section.

\section{Site 801}

Unit I brown pelagic clay from the top of the sequence was not sampled for this study. 


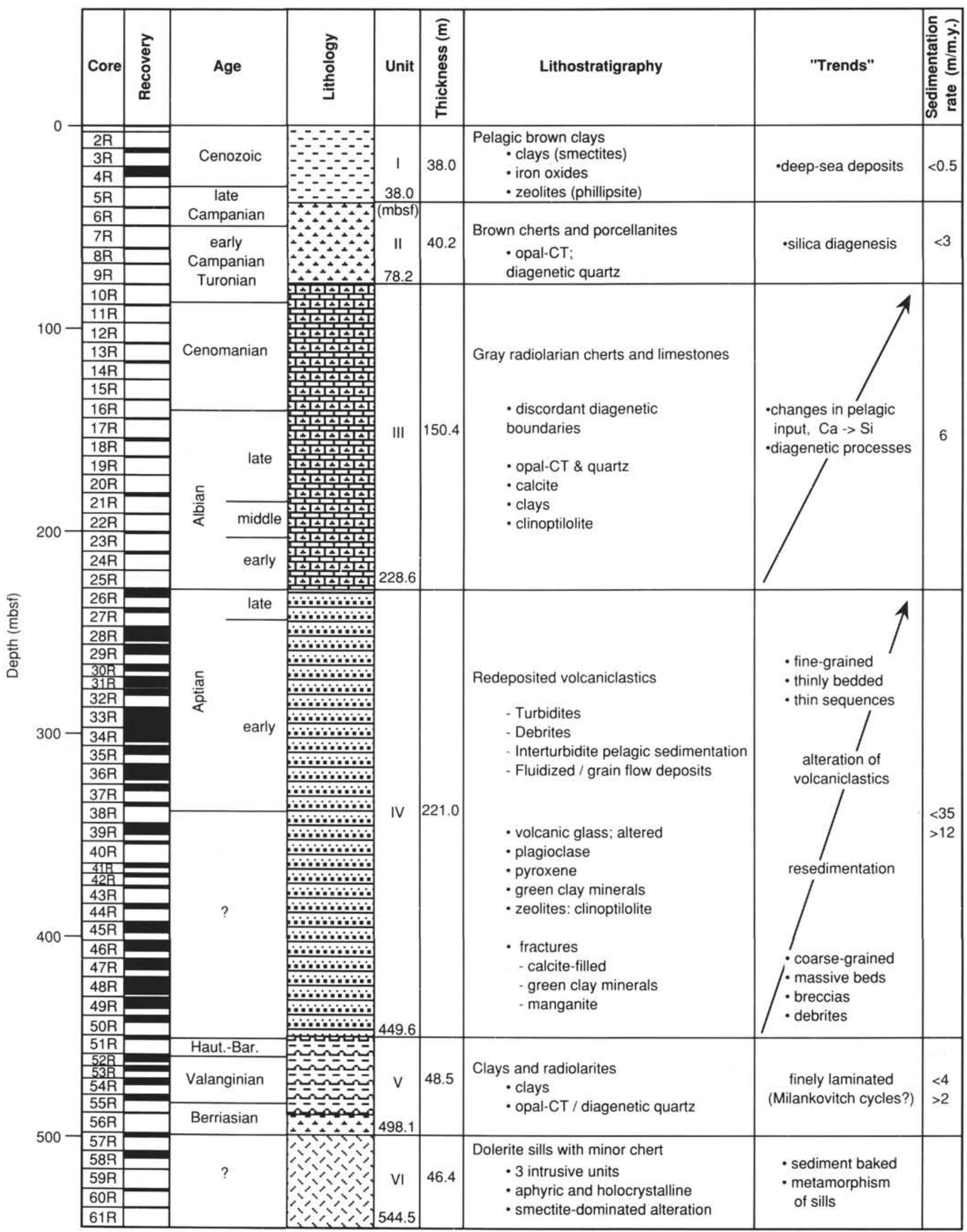

Figure 1. Core ages, lithologies, and units for Site 800, Leg 129 (Lancelot, Larson, et al., 1990). 
Table 1. Sample descriptions for Site 800, Leg 129.

\begin{tabular}{|c|c|c|c|c|c|c|}
\hline Sample (cm) & $\begin{array}{l}\text { Depth } \\
\text { (mbsf) }\end{array}$ & Unit & Age & $\begin{array}{l}\text { Sample } \\
\text { lithology }\end{array}$ & $\begin{array}{l}\text { Compacted } \\
\text { thickness/time } \\
\text { (m/m.y.) }\end{array}$ & $\begin{array}{l}\text { Accumulation } \\
\text { rate }\left(\mathrm{g} / \mathrm{cm}^{2} / \mathrm{m} . \mathrm{y} .\right)\end{array}$ \\
\hline \multicolumn{7}{|l|}{$129-800 \mathrm{~A}-$} \\
\hline $6 \mathrm{R}-1,67-69$ & 40.2 & II & late Campanian & Chert & $<3$ & 600 \\
\hline $7 \mathrm{R}-1,2-5$ & 49.2 & II & early Campanian & Chert & $<3$ & 630 \\
\hline $8 \mathrm{R}-1,48-50$ & 59.4 & II & early Campanian & Chert & $<3$ & 648 \\
\hline $9 \mathrm{R}-1,30-33$ & 68.8 & II & early Campanian/Turonian & Chert & $<3$ & 660 \\
\hline $10 \mathrm{R}-1,13-17$ & 78.3 & III & Turonian & Chert & 6 & 1290 \\
\hline $11 \mathrm{R}-1,7-10$ & 87.9 & III & Cenomanian & Porcellanite & 6 & 1332 \\
\hline $12 R-1,30-32$ & 97.6 & III & Cenomanian & Porcellanite & 6 & 1380 \\
\hline $13 R-1,12-14$ & 106.9 & III & Cenomanian & Porcellanite & 6 & 1380 \\
\hline $14 \mathrm{R}-1,110-115$ & 117.3 & III & Cenomanian & Radiolarite & 6 & 1434 \\
\hline $17 \mathrm{R}-1,68-71$ & 144.9 & III & late Albian & Porcellanite & 6 & 1368 \\
\hline $18 \mathrm{R}-1,127-130$ & 155.0 & III & late Albian & Porcellanite & 6 & 1422 \\
\hline $23 \mathrm{R}-1,69-70$ & 201.2 & III & early Albian & Radiolarite & 6 & 1470 \\
\hline $24 \mathrm{R}-1,92-95$ & 210.6 & III & early Albian & Radiolarite & 6 & 1362 \\
\hline $24 \mathrm{R}-1,68-71$ & 210.8 & III & early Albian & Radiolarite & 6 & 1362 \\
\hline $26 \mathrm{R}-1,22-26$ & 228.8 & IV & late Aptian & Claystone & $12<\mathrm{ct}<35$ & $3192<\mathrm{AR}<9310$ \\
\hline $26 \mathrm{R}-1,135-139$ & 230.0 & IV & late Aptian & Siltstone & $12<\mathrm{ct}<35$ & $3192<\mathrm{AR}<9310$ \\
\hline $27 \mathrm{R}-1,61-64$ & 238.6 & IV & middle(?) Aptian & Siltstone & $12<\mathrm{ct}<35$ & $3240<\mathrm{AR}<9450$ \\
\hline $27 \mathrm{R}-1,110-114$ & 239.1 & IV & middle(?) Aptian & Radiolarite & $12<\mathrm{cl}<35$ & $3120<\mathrm{AR}<9100$ \\
\hline $28 \mathrm{R}-3,106-110$ & 251.3 & IV & early Aptian & Claystone & $12<\mathrm{ct}<35$ & $3168<\mathrm{AR}<9240$ \\
\hline $30 \mathrm{R}-1,125-129$ & 267.2 & IV & early Aptian & Porcellanite & $12<\mathrm{ct}<35$ & $2964<\mathrm{AR}<8645$ \\
\hline $30 \mathrm{R}-2,114-118$ & 268.5 & IV & early Aptian & Radiolarite & $12<\mathrm{ct}<35$ & $3060<\mathrm{AR}<8925$ \\
\hline $31 \mathrm{R}-1,12-14$ & 272.1 & IV & early Aptian & Porcellanite & $12<\mathrm{ct}<35$ & $3072<\mathrm{AR}<8960$ \\
\hline $32 \mathrm{R}-\mathrm{CC}, 10-13$ & 280.8 & IV & early Aptian & Claystone & $12<\mathrm{ct}<35$ & $3216<\mathrm{AR}<9380$ \\
\hline $33 R-7,14-18$ & 296.6 & IV & early Aptian & Claystone & $12<\mathrm{ct}<35$ & $3192<\mathrm{AR}<9310$ \\
\hline $34 \mathrm{R}-2,139-142$ & 299.9 & IV & early Aptian & Claystone & $12<\mathrm{ct}<35$ & $3240<\mathrm{AR}<9450$ \\
\hline $35 \mathrm{R}-3,84-88$ & 310.2 & IV & early Aptian & Siltstone & $12<\mathrm{ct}<35$ & $3228<\mathrm{AR}<9415$ \\
\hline $36 \mathrm{R}-1,110-114$ & 317.0 & IV & early Aptian & Claystone & $12<\mathrm{ct}<35$ & $3240<\mathrm{AR}<9450$ \\
\hline $36 \mathrm{R}-4,28-32$ & 320.7 & IV & early Aptian & Claystone & $12<\mathrm{ct}<35$ & $3000<\mathrm{AR}<8750$ \\
\hline $41 \mathrm{R}-1,87-93$ & 363.4 & IV & Aptian(?) Barremian(?) & Claystone & $12<\mathrm{ct}<35$ & $3300<\mathrm{AR}<9625$ \\
\hline $42 \mathrm{R}-1,41-43$ & 369.0 & IV & Aptian(?) Barremian(?) & Claystone & $12<\mathrm{ct}<35$ & $3300<\mathrm{AR}<9625$ \\
\hline $44 \mathrm{R}-1,92-94$ & 384.6 & IV & Aptian(?) Barremian(?) & Siltstone & $12<\mathrm{ct}<35$ & $3120<\mathrm{AR}<9100$ \\
\hline 51R-1, 106-108 & 450.7 & V & Hauterivian/Barremian & Radiolarite & $2<\mathrm{ct}<4$ & $532<\mathrm{AR}<1064$ \\
\hline $52 \mathrm{R}-1,16-20$ & 459.0 & V & Hauterivian/Barremian & Claystone & $2<\mathrm{ct}<4$ & $536<\mathrm{AR}<1072$ \\
\hline $53 \mathrm{R}-1,32-34$ & 465.2 & V & Hauterivian/Barremian & Radiolarite & $2<\mathrm{ct}<4$ & $518<\mathrm{AR}<1036$ \\
\hline $55 \mathrm{R}-1,76-81$ & 479.9 & V & Berriasian & Radiolarite & $2<\mathrm{ct}<4$ & $530<\mathrm{AR}<1060$ \\
\hline $55 \mathrm{R}-2.25-30$ & 480.9 & V & Berriasian & Radiolarite & $2<\mathrm{ct}<4$ & $530<\mathrm{AR}<1060$ \\
\hline $56 \mathrm{R}-1,8-13$ & 488.6 & V & Berriasian & Chert & $2<\mathrm{ct}<4$ & $492<\mathrm{AR}<984$ \\
\hline $58 \mathrm{R}-1,37-42$ & 507.2 & VI & ? & Chert & $2<\mathrm{ct}<4$ & $500<\mathrm{AR}<1000$ \\
\hline
\end{tabular}

Unit II (Fig. 2) is Campanian to Cenomanian in age and $62 \mathrm{~m}$ thick. Poor recovery for this unit suggests a strong hardness contrast between lithologies recovered and not recovered. Recovered rocks were dominantly chert and porcellanite very similar to that of Unit II at Site 800 . Minor recovered claystone suggests that much of the missing core may have been soft clay or claystone. The chert is pale to dark brown, and finely laminated to banded, with alternating bands of pale brown chert and dark brown porcellanite. Some chert is bioturbated. Fractures are commonly filled with $\mathrm{Mn}$-oxide grains or dendrites. The chert contains up to $35 \%$ radiolarians and variable amounts of clay minerals. The unit is noncalcareous, except at its lower boundary, which is gradational to the underlying turbidite unit: Core $129-801 \mathrm{~A}-13 \mathrm{R}$ contains calcareous radiolarian porcellanite; Cores $129-801 \mathrm{~A}-14 \mathrm{R}$ and $-15 \mathrm{R}$ contain tuffaceous nannofossil claystone and chalk. The samples from Unit II (Table 2) are brown chert except samples from Cores 129-801A-12R and $-13 R$ which are cherty porcellanite.

Unit III is Cenomanian to Albian in age, $92 \mathrm{~m}$ thick, and consists of volcaniclastic turbidites very similar to those of Unit IV at Site 800. Pelagic intervals are represented by radiolarian claystone, radiolarian porcellanite, radiolarite, chert, nannofossil claystone, and chalk. The turbidites are dark greenish to bluish gray with beds up to $5 \mathrm{~m}$ thick, some of which contain shallow-water carbonate debris. The pelagic interbeds are mostly olive green to gray, and have discontinuous laminations or sparse bioturbation. The base of the unit consists of thin-bedded distalfacies turbidites with brown radiolarian claystone or radiolarite intervals up to $1 \mathrm{~cm}$ thick, which is transitional to the underlying radiolarite unit. Samples studied from Unit III consist of pelagic gray to brown radiolarian porcellanite and chert. For purposes of comparison, claystone from the tops of turbidite beds in Sections 129-801A-18R-2 and 129$801 B-8 R-2$ were sampled, and a calcareous porcellanite from Section 129-801B-10R-1 was sampled. This latter sample contained $10 \%$ limestone, $30 \%$ chert, and $60 \%$ porcellanite.

Unit IV is Valanginian to Oxfordian in age, $125 \mathrm{~m}$ thick, and consists mainly of brown radiolarite with subordinate dark brown chert and porcellanite bands and nodules. The unit is subdivided into an upper, chert-rich radiolarite with $10 \%$ or less clay, and a lower radiolarite with $20 \%$ or more clay. Radiolarians comprise up to $90 \%$ of the radiolarite and up to $70 \%$ of the chert. Foraminifers are rare. Sedimentary structures include rare fine laminations, flasers, laminations that grade to radiolarian clay, and rare bioturbation. Porcellanite and chert zones crosscut these features. Black Mn oxides occur as grains, microlaminations, and coatings on fractures. Interstitial $\mathrm{Fe}$ Mn-oxide grains may comprise as much as $20 \%$ of some radiolarite. Shipboard XRD analyses indicate that hematite and smectite are present in addition to various phases of silica in cores from Unit IV. Samples studied from this unit are all radiolarite and chert. The sample from Section 129-801B-26R-CC contains Mn-oxide grains.

Unit V is Callovian in age, $18 \mathrm{~m}$ thick, and consists of interbedded red radiolarite and claystone. There is a distinct color change from brown to red at the upper unit boundary. The layers of radiolarite and claystone alternate on a centimeter scale, and average about $5 \mathrm{~cm}$ in thickness. Layer boundaries are gradational on a millimeter scale, as observed in thin section, suggesting fluctuating depositional conditions. Radiolarite layers contain up to $25 \%$ clay minerals and rare 


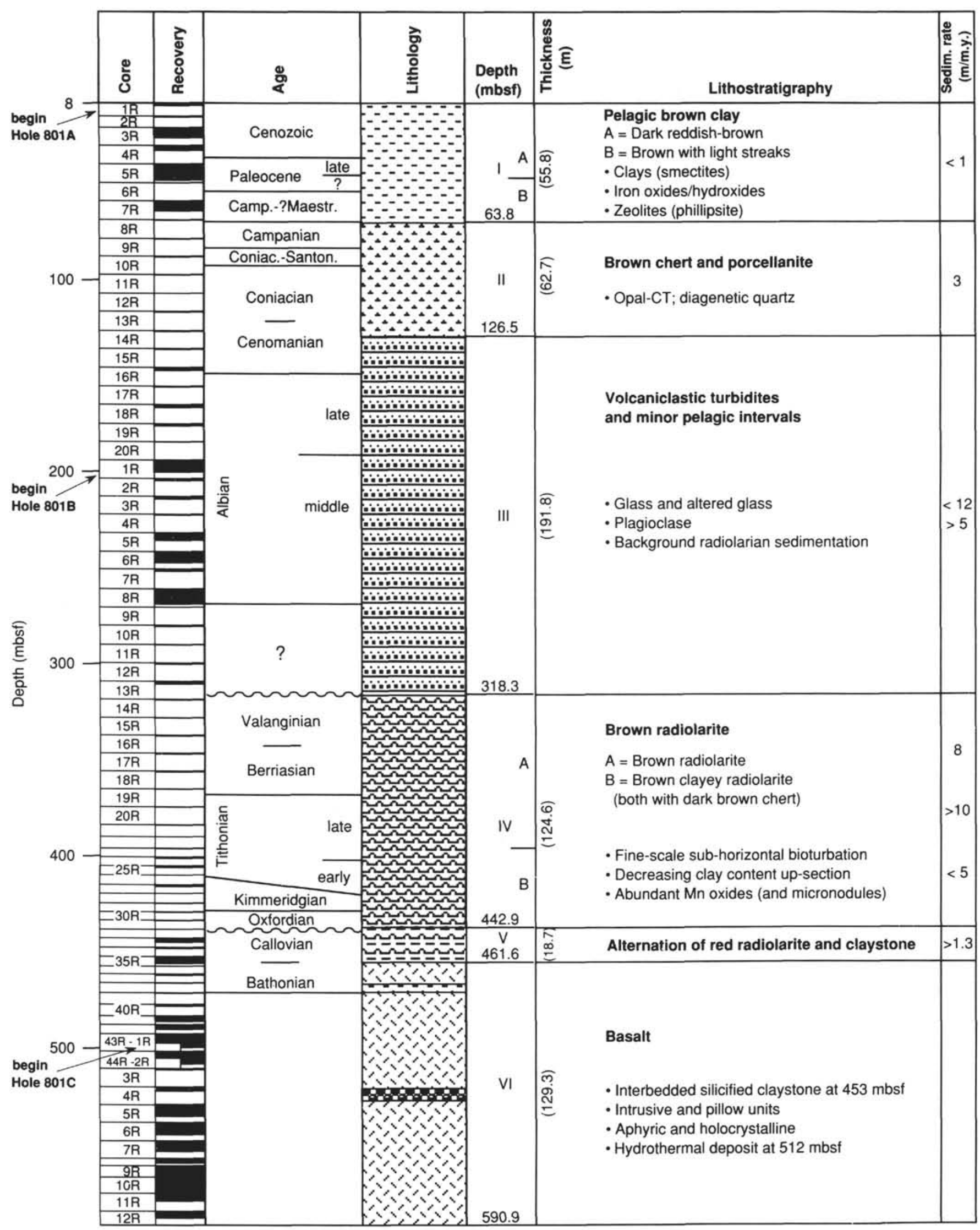

Figure 2. Core ages, lithologies, and units for Site 801, Leg 129 (Lancelot, Larson, et al., 1990). 
Table 2. Sample descriptions for Site 801, Leg 129.

\begin{tabular}{|c|c|c|c|c|c|c|}
\hline Sample (cm) & $\begin{array}{l}\text { Depth } \\
\text { (mbsf) }\end{array}$ & Unit & Age & $\begin{array}{l}\text { Sample } \\
\text { lithology }\end{array}$ & $\begin{array}{l}\text { Compacted } \\
\text { thickness/time } \\
(\mathrm{m} / \mathrm{m} . \mathrm{y} .)\end{array}$ & $\begin{array}{l}\text { Accumulation } \\
\text { rate }\left(g / \mathrm{cm}^{2} / \mathrm{m} . \mathrm{y} \text {.) }\right.\end{array}$ \\
\hline \multicolumn{7}{|l|}{ 129-801A- } \\
\hline $8 \mathrm{R}-1,1-3$ & 60.6 & II & Campanian & Chert & 3 & 687 \\
\hline $9 \mathrm{R}-1,0-3$ & 70.2 & II & Coniacian-Santonian & Chert & 3 & 645 \\
\hline $10 \mathrm{R}-1,0-5$ & 79.5 & II & Coniacian & Chert & 3 & 669 \\
\hline $12 \mathrm{R}-1,22-25$ & 99.0 & II & Cenomanian/Coniacian & Porcellanite & 3 & 699 \\
\hline $80-100 \mathrm{M}$ & 100.0 & II & $?$ & Chert & ? & $?$ \\
\hline $13 \mathrm{R}-1,21-26$ & 108.7 & II & Cenomanian & Porcellanite & 3 & 657 \\
\hline $14 \mathrm{R}-1,26-28$ & 118.5 & II & Cenomanian & Chert & $5<\mathrm{ct}<12$ & $1150<\mathrm{AR}<2760$ \\
\hline $15 \mathrm{R}-1,24-26$ & 128.1 & III & Cenomanian & Chert & $5<\mathrm{ct}<12$ & $1145<\mathrm{AR}<2749$ \\
\hline $16 \mathrm{R}-1,135-138$ & 139.0 & III & late Albian & Porcellanite & $5<\mathrm{ct}<12$ & $1220<\mathrm{AR}<2928$ \\
\hline $17 \mathrm{R}-1,28-30$ & 147.5 & III & late Albian & Porcellanite & $5<\mathrm{ct}<12$ & $1145<\mathrm{AR}<2749$ \\
\hline $18 R-2,14-17$ & 158.6 & III & late Albian & Claystone & $5<\mathrm{ct}<12$ & $1360<\mathrm{AR}<3264$ \\
\hline 19R-CC, $12-16$ & 176.3 & III & late Albian & Claystone & $5<\mathrm{ct}<12$ & $1360<A R<3264$ \\
\hline $20 \mathrm{R}-1,8-12$ & 176.5 & III & middle Albian & Chert & $5<\mathrm{ct}<12$ & $1190<\mathrm{AR}<2856$ \\
\hline
\end{tabular}

129-801B-

\begin{tabular}{|c|c|c|c|c|c|c|}
\hline $8 R-2,60-63$ & 254.8 & III & middle Albian & Clay & $5<\mathrm{ct}<12$ & $1385<\mathrm{AR}<3324$ \\
\hline $10 \mathrm{R}-1,70-73$ & 272.7 & III & Pre-middle Albian, post-Valanginian & Porcellanite & $5<\mathrm{ct}<12$ & $1285<\mathrm{AR}<3084$ \\
\hline $11 R-1.31-36$ & 282.0 & III & Pre-middle Albian & Porcellanite & $5<\mathrm{ct}<12$ & $1285<\mathrm{AR}<3084$ \\
\hline $12 \mathrm{R}-1,64-70$ & 292.0 & III & Pre-middle Albian & Chert & $5<\mathrm{ct}<12$ & $1285<\mathrm{AR}<3084$ \\
\hline $14 \mathrm{R}-1,52-57$ & 310.8 & IVA & Valanginian & Radiolarite & 4 & 1112 \\
\hline $15 \mathrm{R}-1,19-20$ & 319.9 & IVA & Valanginian & Chert & 4 & 1016 \\
\hline $16 \mathrm{R}-1,40-43$ & 329.6 & IVA & Berriasian/Valanginian & Chert & 4 & 1052 \\
\hline $17 \mathrm{R}-1,34-36$ & 338.9 & IVA & Berriasian & Chert & 4 & 1064 \\
\hline $18 \mathrm{R}-1.37-40$ & 348.2 & IVA & Berriasian & Chert & 4 & 1064 \\
\hline $19 \mathrm{R}-1,24-26$ & 357.5 & IVA & Berriasian & Chert & 4 & 1040 \\
\hline $20 \mathrm{R}-1,23-26$ & 366.7 & IVA & late Tithonian & Chert & 4 & 1032 \\
\hline $21 \mathrm{R}-1,12-13$ & 375.8 & IVA & late Tithonian & Chert & 4 & 988 \\
\hline $24 \mathrm{R}-1,69-73$ & 393.3 & IVB & late Tithonian & Radiolarite & 4 & 1016 \\
\hline $25 \mathrm{R}-1,49-53$ & 397.7 & IVB & early Tithonian & Radiolarite & 4 & 1092 \\
\hline 26R-CC. $0-4$ & 407.0 & IVB & early Tithonian & Radiolarite & 4 & 1072 \\
\hline $27 \mathrm{R}-1,104-107$ & 407.7 & IVB & Kimmeridgian & Chert & 4 & 1016 \\
\hline $29 \mathrm{R}-1,17-19$ & 416.4 & IVB & Kimmeridgian & Chert & 4 & 1016 \\
\hline $31 R-1,18-20$ & 425.8 & IVB & Oxfordian & Chert & 4 & 1040 \\
\hline $33 R-1,10-14$ & 434.9 & IVB & Callovian & Radiolarite & 1.3 & 354 \\
\hline $33 R-1,126-129$ & 436.1 & IVB & Callovian & Radiolarite & 1.3 & 354 \\
\hline $35 \mathrm{R}-1,51-55$ & 444.8 & V & Callovian & Clay & 1.3 & 358 \\
\hline $35 \mathrm{R}-1,123-127$ & 445.5 & V & Callovian & Claystone & 1.3 & 358 \\
\hline $37 \mathrm{R}-1,7-10$ & 453.6 & V & Bathonian & Claystone & $?$ & $?$ \\
\hline $39 \mathrm{R}-1,4-7$ & 462.7 & VII & Bathonian & Chert & $?$ & $?$ \\
\hline \multicolumn{7}{|l|}{ 129-801C. } \\
\hline $4 \mathrm{R}-1,11-16$ & 521.8 & VI & $\geq$ Bathonian & Quartz & $?$ & $?$ \\
\hline $5 R-4,11-16$ & 535.8 & VI & $\geq$ Bathonian & Quartz & $?$ & $?$ \\
\hline $6 \mathrm{R}-\mathrm{I}, 3 \mathrm{I}-34$ & 540.8 & VI & $\geq$ Bathonian & Quartz & ? & ? \\
\hline
\end{tabular}

burrows. Color mottling, anastomosing clay seams, and patchy silicification within layers are diagenetic features. Mn oxides on fractures are rare relative to the overlying radiolarite unit. Claystone beds are darker red than the radiolarite beds, contain rare burrows, and less than $25 \%$ radiolarians. The red color indicates oxic conditions throughout the section despite high productivity. Shipboard XRD analyses indicate the presence of hematite and smectite in addition to various phases of quartz. Samples studied from this unit include two samples of radiolarite, one of claystone, and one of soft, unlithified Callovian clay (Sample 129-801B-35R-1, 51-55 cm, Table 2).

Unit VI is Bathonian in age, and consists of basalt flows with interpillow sedimentary rocks. The basalt is interpreted to represent basement (Lancelot, Larson, et al., 1990). Interpillow lithologies include chert, claystone, carbonate, tuff, and hydrothermal quartz. These sedimentary rocks are thermally recrystallized and some are laced with veins of drusy quartz. The chert contains quartz-filled radiolarians. Samples studied from this unit include radiolarian claystone, chert, and three samples from Cores 129-801C-4R,-5R, and -6R of hydrothermal quartz and goethite (Karpoff, this volume).

\section{Site 802}

Unit I consists of brown pelagic clay (Fig. 3). Unit II consists of Miocene volcaniclastic turbidites with intervals of brown pelagic claystone, nannofossil claystone, and nannofossil chalk. No samples were collected from these units for this study.

Unit III is early Miocene to Paleocene in age, $75 \mathrm{~m}$ thick, and consists of nannofossil chalk with minor amounts of claystone, porcellanite, and nodular chert (Lancelot, Larson, et al., 1990). The chalk is thick-bedded, commonly graded, laminated and cross-laminated, and bioturbated. Clasts of claystone are common in the chalk, and mixed assemblages of Cretaceous through Oligocene nannofossils indicate that this chalk is redeposited carbonate ooze. The brown claystone contains clay minerals, zeolites, volcanic glass, iron oxides, radiolarians, and nannofossils. The claystone is extensively bioturbated. Chert occurs as scattered nodules, comprising less than $3 \%$ of the recovered core. The chert has sharp, irregular contacts with the chalk, and often contains carbonate inclusions. The chert is clearly a diagenetic product derived from dissolution of siliceous plankton in 


\begin{tabular}{|c|c|c|c|c|c|c|c|c|}
\hline & ১ั้ & 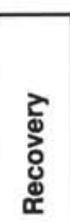 & Age & 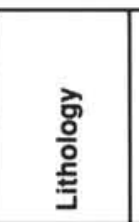 & 言 & 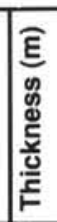 & Lithostratigraphy & 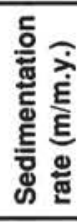 \\
\hline \multirow[t]{8}{*}{$0-$} & $\frac{1 \mathrm{R}}{2 \mathrm{R}}$ & & late Pliocene - Quaternary & $\because \because--1$ & 114.6 & 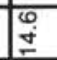 & Pelagic brown clay & low \\
\hline & $3 \mathrm{~A}$ & & late Miocene - middle Pliocene & & & & & \\
\hline & $4 \mathrm{R}$ & & & $(2 \times 2 \times 2 \times 1$ & & & & \\
\hline & $5 \mathrm{R}$ & & & $(2 \times 2 \times 2)$ & & & Tuff & \\
\hline & $\frac{6 R}{7 R}$ & & ? & $2 \times 2 \times 3$ & & & Volcaniclastic turbidites & \\
\hline & $8 \mathrm{R}$ & & & $(x>y$ & & & & 11 \\
\hline & $9 \mathrm{R}$ & & & 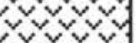 & & & & \\
\hline & $10 \mathrm{~A}$ & & & $(2 \times 2 \times 2$ & A & & & \\
\hline \multirow[t]{9}{*}{$100-$} & $\frac{11 \mathrm{H}}{12 \mathrm{R}}$ & & middle Miocene & $(2 \times 2 \times 3$ & & o. & A. Tuff with nolaric clav & \\
\hline & $\frac{138}{148}$ & & & & & $\exists$ & 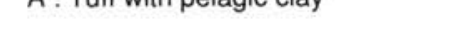 & \\
\hline & $15 \mathrm{~A}$ & & & $2 \times 2 \times 2 \times 3$ & & & & \\
\hline & $16 \mathrm{R}$ & & & $2 \times 1$ & II & & & \\
\hline & $17 \mathrm{R}$ & & & $2 x^{2}+2 \times 2 \times y$ & & & & \\
\hline & $\frac{18 \mathrm{H}}{19 \mathrm{R}}$ & & & $x^{2}-x^{2}-2=1$ & 160.6 & & & \\
\hline & $20 \mathrm{R}$ & & & 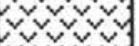 & & & & \\
\hline & $21 R$ & & & & & & & \\
\hline & $22 R$ & & early Miocene & $x<>>y$ & & & B : Tuff with calcareous claystone & \\
\hline \multirow{4}{*}{$200-$} & $\frac{23 R}{24 R}$ & & & 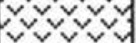 & $\mathrm{B}$ & $\infty$ & & 10 \\
\hline & $25 \mathrm{R}$ & & & $\left(x^{2} \times 2 \times 2 \times 2 \times 2\right.$ & & & & \\
\hline & $26 \mathrm{R}$ & & & & 2374 & & & \\
\hline & $27 R$ & & & 竞竞 & & & & \\
\hline \multirow[b]{5}{*}{$300->+2-2$} & $28 \mathrm{R}$ & & & & & & & \\
\hline & $\frac{29 \mathrm{H}}{30 \mathrm{~B}}$ & & & & & & & 12 \\
\hline & $31 \mathrm{R}$ & & & & $\mu$ & & & \\
\hline & $32 \mathrm{R}$ & & ? late Oligocene & & III & in & Nannofossil chalk & \\
\hline & $33 R$ & & early Eocene & 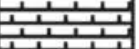 & & & & \\
\hline \multirow{8}{*}{$300-$} & $34 R$ & & & & & & & 7 \\
\hline & $35 R$ & & Paleocene & & 3299 & & & $r$ \\
\hline & $\frac{36 \mathrm{R}}{37 \mathrm{R}}$ & & & & IV & m & & \\
\hline & $38 \mathrm{R}$ & & & & 349.2 & $\sigma^{\circ}$ & Claystone & $2-4$ \\
\hline & $39 R$ & & & (nنं & & & & \\
\hline & $\frac{40 R}{41 R}$ & & late Campanian & 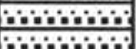 & & & & \\
\hline & $42 \mathrm{R}$ & & & 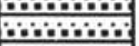 & & & & \\
\hline & $43 R$ & & & | & & & & \\
\hline \multirow{10}{*}{$400-$} & $44 \mathrm{R}$ & & & فين门i & & & & \\
\hline & $45 \mathrm{R}$ & & & | & $\mathrm{v}$ & 우 & Volcaniclastic turbidites & 9 \\
\hline & $46 \mathrm{R}$ & & Santonian & |inininin & & & & \\
\hline & $47 \mathrm{R}$ & & & ط: & & & & \\
\hline & $48 \mathrm{R}$ & & & 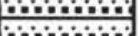 & & & & \\
\hline & $49 \mathrm{R}$ & & & ن & & & & \\
\hline & $\frac{50 \mathrm{n}}{518}$ & & Coniacian & | & 460.0 & & & \\
\hline & $52 \mathrm{~A}$ & & ? ?- & & $\mathrm{VI}$ & & Claystone and radiolarite & 2 \\
\hline & $\frac{53 \mathrm{~A}}{54 \mathrm{~B}}$ & & Cenomanian & 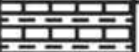 & 469.9 & |ง & Calcareous claystone & \\
\hline & $\frac{54 \mathrm{~B}}{55 \mathrm{R}}$ & & - & & 4971 & ก & and radiolarian limestone & 1.5 \\
\hline \multirow[t]{6}{*}{$500-$} & $56 \mathrm{R}$ & & ? late Aptian & 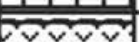 & $\mathrm{VH}-\overline{\bar{x}}$ & & Claystone-volcanic turbidites & \\
\hline & $57 \mathrm{R}$ & & & & 509.2 & & & \\
\hline & $58 \mathrm{R}$ & & & & & & Basalt & \\
\hline & $59 \mathrm{~A}$ & & & & $\mathrm{x}$ & $\stackrel{\leftrightarrow}{\circ}$ & • Pillow units & \\
\hline & $60 \mathrm{R}$ & & & & & In & - Sparsely microphyric and & \\
\hline & $\frac{618}{62 R}$ & & & & 559.8 & & hypocrystalline & \\
\hline
\end{tabular}

Figure 3. Core ages, lithologies, and units for Site 802, Leg 129 (Lancelot, Larson, et al., 1990). 
Table 3. Sample descriptions for Site 802, Leg 129.

\begin{tabular}{|c|c|c|c|c|c|c|}
\hline Sample $(\mathrm{cm})$ & $\begin{array}{l}\text { Depth } \\
\text { (mbsf) }\end{array}$ & Unit & Age & $\begin{array}{c}\text { Sample } \\
\text { lithology }\end{array}$ & $\begin{array}{l}\text { Compacted } \\
\text { thickness/time } \\
(\mathrm{m} / \mathrm{m} . \mathrm{y} .)\end{array}$ & $\begin{array}{l}\text { Accumulation } \\
\text { rate }\left(\mathrm{g} / \mathrm{cm}^{2} / \mathrm{m} \text {.y. }\right)\end{array}$ \\
\hline \multicolumn{7}{|l|}{$129-802 \mathrm{~A}-$} \\
\hline $33 \mathrm{R}-1,116-120$ & 294.0 & III & early Eocene & Limestone & 7 & 1897 \\
\hline $34 \mathrm{R}-1,128-132$ & 303.6 & III & early Eocene & Chert & 7 & 1785 \\
\hline $35 \mathrm{R}-\mathrm{CC}, 0-4$ & 320.5 & III & late Paleocene & Chert & 7 & 1785 \\
\hline $37 \mathrm{R}-1,11-15$ & 330.0 & IV & late Paleocene & Chert & $?$ & $?$ \\
\hline $38 \mathrm{R}-\mathrm{CC}, 12-15$ & 348.6 & IV & late Campanian & Mudstone & ? & $?$ \\
\hline $39 \mathrm{R}-1,10-15$ & 348.8 & IV & late Campanian & Porcellanite & 7 & 1869 \\
\hline $43 \mathrm{R}-1,75-78$ & 382.9 & V & Santonian & Porcellanite & 7 & 1869 \\
\hline $52 \mathrm{R}-2,125-130$ & 462.6 & VI & Coniacian/Cenomanian(?) & Radiolarite & 5.5 & 1391 \\
\hline $55 \mathrm{R}-1,138-141$ & 489.3 & VII & Cenomanian & Radiolarite & 5.5 & 1397 \\
\hline $56 \mathrm{R}-1,43-47$ & 497.5 & VIII & late Aptian(?) & Radiolarite & 5.5 & 1397 \\
\hline $56 \mathrm{R}-2,88-92$ & 499.5 & VIII & late Aptian(?) & Mudstone & 5.51 & 452 \\
\hline
\end{tabular}

the chalk. Samples studied from Unit III (Table 3) include radiolarian limestone with Mn-oxide micronodules and red chert nodules with minor chalk inclusions.

Unit IV is Paleocene to late Campanian in age, $19 \mathrm{~m}$ thick, and consists of zeolitic pelagic claystone with subordinate nannofossil claystone, porcellanite, chert, and calcareous siltstone and sandstone (Lancelot, Larson, et al., 1990). The claystone contains 15\%-40\% zeolites, $3 \%-10 \%$ radiolarians, and scattered $\mathrm{Fe}-\mathrm{Mn}$ oxyhydroxides. The Fe-Mn oxyhydroxides are indicators of deep-water deposition and slow accumulation rates; they are not found in continental margin deposits or areas with high accumulation rates. The claystone is thinly laminated and commonly bioturbated. Some beds are graded or cross-laminated, and some have convolute layers or flame structures, indicating that they were deposited as turbidites. The samples studied from Unit IV include a millimeter-laminated chert nodule from chalk, calcareous radiolarian mudstone, and massive brown porcellanite.

Unit V is late Campanian to Cenomanian in age, $111 \mathrm{~m}$ thick, and consists dominantly of volcaniclastic turbidites up to $1 \mathrm{~m}$ thick. Pelagic intervals are represented by claystone containing up to $20 \%$ radiolarians and/or nannofossils, which gradationally overlies tuffaceous claystone. The sample studied from this unit is a greenish gray, slightly calcareous porcellanite from the top of a turbidite bed.

Unit VI is Cenomanian in age, $10 \mathrm{~m}$ thick, and consists of interbedded brown claystone and radiolarite (Lancelot, Larson, et al., 1990). The claystone contains clay minerals, Fe-Mn oxides, zeolites, and radiolarians in layers up to $125 \mathrm{~cm}$ thick. Radiolarite occurs in beds less than $4 \mathrm{~cm}$ thick and ranges from green to gray to brown. Contacts between layers are gradational in some places and sharp in others. The sample studied from Unit VI is a centimeter-scale bedded buff-colored radiolarite and reddish brown clay. Bedding contacts within the sample are sharp, not graded, suggesting alternating depositional conditions.

Unit VII is Cenomanian to late Aptian in age and consists of $27 \mathrm{~m}$ of radiolarian limestone, nannofossil chalk, calcareous claystone, clayey sandstone, radiolarite, porcellanite, and chert (Lancelot, Larson, et al., 1990). Beds are laminated to massive and vary from a millimeter to more than a meter thick. The unit boundaries are defined by the occurrence of carbonate rocks at the top and the base. The sample studied from this unit is a laminated radiolarite with rare $\mathrm{Fe}-\mathrm{Mn}$ micronodules, which is similar to radiolarite from Unit VI.

Unit VIII is late Aptian(?) in age and consists of $2 \mathrm{~m}$ of claystone with thin interbeds of radiolarite (Lancelot, Larson, et al., 1990). The claystone is yellowish-brown, thinly laminated, contains Fe oxides, zeolites, Fe-Mn micronodules, and pyritized burrows. Sharp, discrete, plane-laminated beds suggest current deposition, whereas scour and grading in some beds suggest turbidite deposition. Radiolarite beds are $1-4 \mathrm{~cm}$ thick, comprising approximately $10 \%$ of recovered core. Some radiolarite beds are graded, with sharp contacts, suggesting turbidite deposition. Samples studied from Unit VIII include millimeter-laminated radiolarite with radiolarian claystone, and radiolarian claystone.

\section{PALEOMAGNETIC CONSTRAINTS ON LEG 129 SITES}

The Mesozoic Pacific Ocean, as reconstructed from magnetic data, was larger than the modern Pacific Ocean (Larson and Pittman, 1973) but had a strong equatorial current and wind patterns that approximately resembled modern patterns (Kennett, 1982). Magnetic data were used to determine paleolatitudes for Sites 800,801 , and 802 (Lancelot, Larson, et al., 1990; Steiner and Wallick, this volume; Ogg et al., this volume), providing geographic constraints for deposition of various lithologic units.

\section{Site $\mathbf{8 0 0}$}

The oldest sediments and sedimentary rocks recovered from Site 800 are Berriasian, at which time the site was located at approximately $2^{\circ} \mathrm{S}$ and moving southward on the Pacific plate (Ogg et al., this volume). This location would have been in the equatorial zone of high productivity (Bostrom, 1976), during accumulation of the radiolarite of Unit V. The site migrated to approximately $13^{\circ} \mathrm{S}$, and started moving northward during the Aptian. During the Albian when siliceous limestone of Unit III was deposited, the site was still south of the equator. Accumulation of the radiolarian chert of Unit II corresponds to subsequent transition of the site to north of the equator, and brown pelagic clay of Unit I marks passage into the northern Pacific province of low accumulation.

\section{Site 801}

Site 801 was situated approximately $9^{\circ}$ south of the equator during deposition of radiolarite and claystone of Unit V in the Callovian, and migrated as far north as $1^{\circ} \mathrm{S}$ of the equator during deposition of the radiolarite of Unit IV in the Tithonian (Ogg et al., this volume). The site moved southward during deposition of the volcaniclastic turbidites of Unit III. During the Aptian, Site 801 reached $16^{\circ} \mathrm{S}$ before migrating northward. At this maximum southern latitude for this site, radiolarite, radiolarian claystone, and calcareous claystone were deposited between turbidite events as background sedimentation. The site crossed the equator during deposition of brown chert and porcellanite of Unit II in the Late Cretaceous. In the Maestrichtian, the site migrated north of $5^{\circ} \mathrm{N}$, into the North Pacific Basin, where Unit I brown pelagic clay was deposited.

\section{Site 802}

Site 802 was situated slightly south of the equator during deposition of radiolarite, claystone, and turbidites of Units V through VIII 
in the middle to Late Cretaceous (Lancelot, Larson, et al., 1990). Moving northward, it crossed the equator during accumulation of Late Cretaceous to early Paleocene radiolarian claystone of Unit IV, and chalk of Unit III accumulated within a few degrees of the equator. Clay and turbidites of Units I and II were deposited north of the equatorial zone in the late Tertiary to Quaternary.

\section{PALEOCEANOGRAPHIC CONDITIONS}

The sequence of deposition at Sites 800,801 , and 802 indicates that the conditions of deposition were not symmetrical about the equator or homogenous in the equatorial province, nor were they consistent over time. Upwelling of nutrients caused by current shear between the northern and southern gyres in the Mesozoic Pacific resulted in high productivity in this zone of divergence at the equator (Heath and Moberly, 1971). Higher productivity results in higher accumulation rates because biogenic material is exposed for less time at the seafloor, and consequently less dissolves in corrosive, $\mathrm{Si}$ and Ca undersaturated bottom waters (Berger, 1976). As a result of these conditions, in deep water, higher accumulation rates are represented by radiolarite and limestone; lower accumulation rates are represented by claystone. In the Jurassic, radiolarite was deposited between an unknown north latitude and at least $9^{\circ} \mathrm{S}$, with slightly higher accumulation rates closer to the equator; no evidence of calcareous deposition remains, although calculated subsidence curves suggest Site 801 may have been near the carbonate compensation depth (CCD) (Ogg et al., this volume). In the Cretaceous, radiolarite was deposited between approximately $5^{\circ} \mathrm{N}$ and $16^{\circ} \mathrm{S}$; calcareous biogenic material was deposited between about $2^{\circ} \mathrm{S}$ to $10^{\circ} \mathrm{S}$. Although sedimentary structures indicative of turbidite deposition were not observed in Cretaceous calcareous deposits cored, faunal evidence (Erba, this volume; Matsuoka, this volume) suggests at least some of the calcareous sediments were redeposited. These calcareous deposits, recorded at Site 800 and in rare pelagic intervals between volcaniclastic turbidites at Sites 801 and 802, accumulated below the inferred $\mathrm{CCD}$ for the Cretaceous (see Ogg et al., this volume). Even if all of the Cretaceous calcareous sediments were redeposited, it is significant that calcareous material was available, since none was deposited or redeposited at shallower depths in the Jurassic. The distribution of this calcareous sedimentation (observed only for time intervals when these sites were located south of the equator) also suggests that productivity was higher on the southern flank of the equatorial zone than on the northern flank. Accumulation rates for background sediments in the volcaniclastic turbidite units could not be calculated, but the presence of radiolarite in Cores $129-800 A-42 R$ and $-43 R$, and Cores 129-801B-8R through -12R, and calcareous claystone in Core 129-800A-36R, during which time these sites were at their farthest south latitudes, suggests relatively high accumulation rates based on the criteria mentioned above. In addition, accumulation rates were lower for the brown chert and porcellanite units (Units II), which represent the equator crossings at Sites 800 and 801 , than accumulation rates for radiolarite or limestone deposited south of the equator during the Late Jurassic and Early Cretaceous. Leg 129 data indicates that accumulation rates decline rapidly north of the equator (Figs. 1, 2, and 3; Tables 4, 5, and 6; Ogg et al., this volume). This observation is in conflict with the curve of accumulation rates for other Pacific sites representing equatorial paleolatitudes plotted in Ogg et al. (this volume, fig. 11), and may reflect local variations in sedimentation or accumulation rate, or differences in productivity and accumulation between Early and Late Cretaceous. The combination of factors controlling the presence of laminated, current-laid, bioturbated, pelagic, or turbiditic deposits of biogenic material at Leg 129 sites is poorly understood in detail.

In the Tertiary background sedimentation north of the equator was clay with less than $10 \%$ siliceous or calcareous biogenic material at very low accumulation rates; we do not have data for this area of the Pacific south of the equator during the Tertiary. The low accumulation rates and low proportion of biogenic material for this claystone also suggest lower productivity in the Tertiary than for the same latitudes in the Late Cretaceous.

In the Late Jurassic to Early Cretaceous, the accumulation rate for biogenic material in the equatorial divergence zone, which apparently extended several degrees south of the equator, was approximately $1000 \mathrm{~g} / \mathrm{cm}^{2} / \mathrm{m}$.y. for Leg 129 sites; during the Late Cretaceous the rate for the same calculated latitude was in the range of $1400 \mathrm{~g} / \mathrm{cm}^{2} / \mathrm{m}$.y. Immediately north of the equator, accumulation rates for non-redeposited biogenic material in the Late Cretaceous were less than $700 \mathrm{~g} / \mathrm{cm}^{2} / \mathrm{m}$.y., and less than $200 \mathrm{~g} / \mathrm{cm}^{2} / \mathrm{m}$.y. in the Tertiary for Leg 129 sites. North of the equatorial divergence zone, accumulation rates were less than $300 \mathrm{~g} / \mathrm{cm}^{2} / \mathrm{m} . y$. in the Late Cretaceous and less than 200 $\mathrm{g} / \mathrm{cm}^{2} / \mathrm{m}$.y. in the Tertiary.

Accumulation rates for background sedimentation may have changed with respect to time and location during the Mesozoic and Cenozoic for various reasons. Nonsymmetrical equatorial deposition interpreted from Leg 129 stratigraphy may have been a function of (1) differences in relative vigor between the northern and southern Pacific current gyres, (2) continent configurations and wind patterns, and (3) nutrient input differences between the arctic and antarctic. Factors affecting sedimentation of Leg 129 deposits over time include the following: (1) small-and large-scale climatic changes that affected the width and productivity of the equatorial province (see Ogg et al., this volume), (2) oceanographic changes in carbonate budget and relative productivity of calcareous and siliceous organisms, (3) subsidence and heat flow on the flanks of the mid-Pacific spreading ridges, (4) local vs. regional intensity of the Cretaceous volcanic events, and (5) frequency of turbidites that mask local depositional conditions. Factors affecting accumulation, such as productivity, rate of deposition and burial, and corrosivity of bottom waters also strongly influenced the depositional sequence at these sites.

Pelagic clay minerals throughout the stratigraphic section at all three sites are dominantly smectites (shipboard data and Karpoff, this volume) and may be dominantly authigenic clay minerals, as described by Heath et al. (1974), or they may signify redistribution of volcanogenic material through time. Although the main episodes of volcanic activity in the vicinity of Leg 129 deposits occurred during the mid- to Late Cretaceous and Miocene, as indicated by the volcanic sills and volcaniclastic deposits, reworking of the volcaniclastic sediments by turbidites and bottom currents, as described by Kelts and Arthur (1981), may have been an important process.

\section{Jurassic}

Homogenous radiolarite of Unit IV at Site 801 accumulated at approximately $1000 \mathrm{~g} / \mathrm{cm}^{2} / \mathrm{m}$.y. under oxic conditions during the Late Jurassic. Deposition was sufficiently rapid to prevent complete dissolution of radiolarians but slow enough to maintain oxic conditions south of the equator. The diagenetic growth of manganese micronodules, some of which are found inside radiolarian tests, suggests there was some period of exposure at the seafloor.

\section{Cretaceous}

Alternating pelagic claystone and radiolarite of Unit $\mathrm{V}$ deposited $2^{\circ} \mathrm{S}$ to $10^{\circ} \mathrm{S}$ during the Early Cretaceous at Site 800 reflect changes in productivity. This might be a consequence of changes in nutrient availability, which can be enhanced during cooler global climates which force stronger circulation between the poles and equator (Arthur et al., 1984). When these conditions are cyclic, they correspond to Milankovich cycles, and may contribute to depositional alternations such as were recorded at Sites 800 and 801 (Ogg and Molinie, this volume; Ogg et al., this volume). Conditions apparently changed by the time Site 800 returned to the same latitudes in the Late Cretaceous, at which time more homogenous radiolarian chert and limestone of Unit III were deposited at a greater accumulation rate than the alternating radiolarite and claystone of Unit V. 
Table 4. Silica contents (in percent) of samples from Site 800, Leg 129.

\begin{tabular}{|c|c|c|c|c|c|c|c|c|c|}
\hline \multirow[b]{2}{*}{ Sample $(\mathrm{cm})$} & \multirow[b]{2}{*}{$\begin{array}{l}\text { Depth } \\
\text { (mbsf) }\end{array}$} & \multirow[b]{2}{*}{ Unit } & \multicolumn{4}{|c|}{ Percentage of sample } & \multicolumn{3}{|c|}{ Percentage of total silica } \\
\hline & & & $\begin{array}{l}\text { Total } \\
\mathrm{SiO}_{2}\end{array}$ & $\begin{array}{c}\text { Biogenic } \\
\mathrm{SiO}_{2}\end{array}$ & $\begin{array}{l}\text { Hydrothermal } \\
\qquad \mathrm{SiO}_{2}\end{array}$ & $\begin{array}{c}\text { Detrital } \\
\mathrm{SiO}_{2}\end{array}$ & $\begin{array}{c}\text { Biogenic } \\
\mathrm{SiO}_{2}\end{array}$ & $\begin{array}{l}\text { Hydrothermal } \\
\mathrm{SiO}_{2}\end{array}$ & $\begin{array}{c}\text { Detrital } \\
\mathrm{SiO}_{2}\end{array}$ \\
\hline \multicolumn{10}{|l|}{$129-800 \mathrm{~A}-$} \\
\hline $6 \mathrm{R}-1,7$ & 39.7 & II & 85.5 & 71.0 & 0.0 & 14.5 & 83.0 & 0.0 & 17.0 \\
\hline $6 \mathrm{R}-1,37$ & 40.0 & II & 80.8 & 63.3 & 0.0 & 17.5 & 78.4 & 0.0 & 21.6 \\
\hline $6 \mathrm{R}-1,67-69$ & 40.2 & II & 87.3 & 79.6 & 0.0 & 7.7 & 91.2 & 0.0 & 8.8 \\
\hline $7 \mathrm{R}-1,2-5$ & 49.2 & II & 89.3 & 83.4 & 0.0 & 5.9 & 93.3 & 0.0 & 6.7 \\
\hline $7 \mathrm{R}-1,66$ & 49.8 & II & 92.0 & 87.1 & 0.0 & 5.0 & 94.6 & 0.0 & 5.4 \\
\hline $8 \mathrm{R}-1,01$ & 58.9 & II & 87.5 & 77.9 & 0.0 & 9.6 & 89.1 & 0.0 & 10.9 \\
\hline $8 \mathrm{R}-1,22$ & 59.1 & II & 89.0 & 80.8 & 0.0 & 8.3 & 90.7 & 0.0 & 9.3 \\
\hline $8 \mathrm{R}-1,48-50$ & 59.4 & II & 87.6 & 80.8 & 0.0 & 6.8 & 92.3 & 0.0 & 7.7 \\
\hline $9 R-1,30-33$ & 68.8 & II & 86.6 & 79.3 & 0.1 & 7.2 & 91.5 & 0.1 & 8.3 \\
\hline $10 \mathrm{R}-1,13$ & 78.3 & III & 92.8 & 86.9 & 1.0 & 5.0 & 93.6 & 1.1 & 5.3 \\
\hline 10R-1, 13-17 & 78.3 & III & 89.6 & 83.9 & 0.4 & 5.3 & 93.7 & 0.5 & 5.9 \\
\hline $11 \mathrm{R}-1,7-10$ & 87.9 & III & 82.8 & 75.7 & 0.0 & 7.1 & 91.4 & 0.0 & 8.6 \\
\hline $12 \mathrm{R}-1,30-32$ & 97.6 & III & 85.6 & 76.5 & 0.0 & 9.1 & 89.4 & 0.0 & 10.6 \\
\hline $12 \mathrm{R}-1,37$ & 97.7 & III & 90.6 & 82.7 & 0.0 & 7.9 & 91.3 & 0.0 & 8.7 \\
\hline $13 \mathrm{R}-1,12-14$ & 106.9 & III & 89.8 & 84.1 & 0.1 & 5.6 & 93.7 & 0.1 & 6.2 \\
\hline $13 \mathrm{R}-1,46$ & 107.2 & III & 69.1 & 66.8 & 0.0 & 2.3 & 96.7 & 0.0 & 3.3 \\
\hline $14 \mathrm{R}-1,101$ & 117.2 & III & 93.0 & 88.1 & 0.0 & 5.0 & 94.7 & 0.0 & 5.3 \\
\hline $14 \mathrm{R}-1,110-115$ & 117.3 & III & 78.2 & 63.7 & 0.0 & 14.5 & 81.4 & 0.0 & 18.6 \\
\hline $17 \mathrm{R}-1,25$ & 144.4 & III & 62.2 & 59.6 & 0.0 & 2.6 & 95.8 & 0.0 & 4.2 \\
\hline $17 \mathrm{R}-1,68-71$ & 144.9 & III & 85.2 & 76.1 & 0.0 & 9.1 & 89.3 & 0.0 & 10.7 \\
\hline $18 \mathrm{R}-1,70$ & 154.4 & III & 83.6 & 70.7 & 0.0 & 12.9 & 84.6 & 0.0 & 15.4 \\
\hline $18 \mathrm{R}-1,121$ & 154.9 & III & 92.0 & 87.1 & 0.0 & 5.0 & 94.6 & 0.0 & 5.4 \\
\hline $18 \mathrm{R}-1,127-130$ & 155.0 & III & 88.9 & 82.7 & 0.0 & 6.2 & 93.0 & 0.0 & 7.0 \\
\hline $19 \mathrm{R}-1,1$ & 162.9 & III & 85.5 & 74.0 & 0.0 & 11.6 & 86.5 & 0.0 & 13.5 \\
\hline $19 \mathrm{R}-1,37$ & 163.3 & III & 80.1 & 61.5 & 0.5 & 18.2 & 76.8 & 0.6 & 22.7 \\
\hline 21R-2, 8 & 182.9 & III & 48.7 & 47.1 & 0.0 & 1.7 & 96.6 & 0.0 & 3.4 \\
\hline $22 \mathrm{R}-1,19$ & 191.2 & III & 33.6 & 11.2 & 0.3 & 22.1 & 33.4 & 0.8 & 65.8 \\
\hline $23 \mathrm{R}-1,69-70$ & 201.2 & III & 83.9 & 74.1 & 0.6 & 9.2 & 88.3 & 0.7 & 11.0 \\
\hline $24 \mathrm{R}-1,30$ & 210.2 & III & 85.3 & 74.1 & 0.4 & 10.9 & 86.8 & 0.4 & 12.8 \\
\hline $24 R-1,68-71$ & 210.6 & III & 79.4 & 64.2 & 0.0 & 15.2 & 80.8 & 0.0 & 19.2 \\
\hline $24 \mathrm{R}-1,92-95$ & 210.8 & III & 90.4 & 85.2 & 0.0 & 5.2 & 94.3 & 0.0 & 5.7 \\
\hline $26 \mathrm{R}-1,22-26$ & 228.8 & IV & 46.2 & 36.2 & 0.4 & 9.6 & 78.4 & 0.9 & 20.7 \\
\hline $26 \mathrm{R}-1,135-139$ & 230.0 & IV & 55.0 & 31.3 & 1.4 & 22.3 & 56.8 & 2.5 & 40.6 \\
\hline $27 \mathrm{R}-1,61-64$ & 238.6 & IV & 55.0 & 27.0 & 1.7 & 26.3 & 49.0 & 3.1 & 47.8 \\
\hline $27 \mathrm{R}-1,110-114$ & 239.1 & IV & 72.8 & 59.9 & 1.1 & 11.8 & 82.2 & 1.6 & 16.2 \\
\hline $28 \mathrm{R}-3,106-110$ & 251.3 & IV & 48.6 & 11.3 & 2.3 & 35.0 & 23.3 & 4.7 & 72.0 \\
\hline $30 \mathrm{R}-1,125-129$ & 267.2 & IV & 75.6 & 56.6 & 1.0 & 17.9 & 74.9 & 1.4 & 23.7 \\
\hline $30 \mathrm{R}-2,114-118$ & 268.5 & IV & 85.7 & 75.8 & 0.8 & 9.1 & 88.5 & 0.9 & 10.6 \\
\hline 3IR-I, 12-14 & 272.1 & IV & 74.0 & 54.4 & 0.0 & 19.6 & 73.6 & 0.0 & 26.4 \\
\hline 32R-CC, $10-13$ & 280.8 & IV & 70.0 & 46.7 & 0.6 & 22.7 & 66.7 & 0.9 & 32.4 \\
\hline $33 R-7,14-18$ & 296.6 & IV & 42.6 & 5.7 & 4.1 & 32.8 & 13.4 & 9.7 & 76.9 \\
\hline $34 \mathrm{R}-2,139-142$ & 299.9 & IV & 42.3 & 13.4 & 2.7 & 26.2 & 31.6 & 6.4 & 62.0 \\
\hline $35 \mathrm{R}-3,84-88$ & 310.2 & IV & 67.1 & 41.3 & 2.8 & 23.0 & 61.6 & 4.1 & 34.3 \\
\hline $36 \mathrm{R}-1,110-114$ & 317.0 & IV & 40.6 & 6.0 & 3.0 & 31.6 & 14.8 & 7.3 & 77.9 \\
\hline $36 \mathrm{R}-4,28-32$ & 320.7 & IV & 42.3 & 5.3 & 3.3 & 33.7 & 12.6 & 7.8 & 79.6 \\
\hline $41 \mathrm{R}-1,87-93$ & 363.4 & IV & 43.3 & 9.3 & 5.9 & 28.1 & 21.4 & 13.7 & 64.9 \\
\hline $42 \mathrm{R}-1,41-43$ & 369.0 & IV & 57.0 & 24.5 & 3.2 & 29.3 & 42.9 & 5.6 & 51.5 \\
\hline $44 \mathrm{R}-1,92-94$ & 384.6 & IV & 44.5 & 6.1 & 7.8 & 30.6 & 13.7 & 17.5 & 68.8 \\
\hline 51R-1, 106-108 & 450.7 & V & 80.2 & 62.8 & 0.0 & 17.4 & 78.3 & 0.0 & 21.7 \\
\hline $52 \mathrm{R}-1,16-20$ & 459.0 & $\mathrm{v}$ & 73.3 & 49.4 & 0.0 & 23.9 & 67.4 & 0.0 & 32.6 \\
\hline $53 \mathrm{R}-1,32-34$ & 465.2 & $\mathrm{v}$ & 81.0 & 66.7 & 0.4 & 13.9 & 82.3 & 0.5 & 17.2 \\
\hline $55 \mathrm{R}-1,76-81$ & 479.9 & $\mathrm{v}$ & 83.1 & 71.1 & 0.0 & 12.0 & 85.5 & 0.0 & 14.5 \\
\hline $55 \mathrm{R}-2,25-30$ & 480.9 & $\mathrm{~V}$ & 79.8 & 62.2 & 0.0 & 17.6 & 78.0 & 0.0 & 22.0 \\
\hline $56 \mathrm{R}-1,8-13$ & 488.6 & $\mathrm{~V}$ & 87.0 & 76.8 & 0.0 & 10.2 & 88.3 & 0.0 & 11.7 \\
\hline $58 \mathrm{R}-1,37-42$ & 507.6 & VI & 95.7 & 93.8 & 0.0 & 1.9 & 98.0 & 0.0 & 2.0 \\
\hline
\end{tabular}

Notes: Ratios and equations from Heath and Dymond (1977) and Bishoff et al. (1979). Detrital $\mathrm{SiO}_{2} \%=3.3\left(\mathrm{Al}_{2} \mathrm{O}_{3} \%\right)$; hydrothermal SiO $\%$ $=1.74\left[\left(\mathrm{Fe}_{2} \mathrm{O}_{3}-0.75 \mathrm{Al}_{2} \mathrm{O}_{3}\right)-0.32 \mathrm{MnO}\right] ;$ biogenic $\mathrm{SiO}_{2} \%=$ total $\mathrm{SiO}_{2} \%$-hydrothermal $\mathrm{SiO}_{2} \%$.

In the Early Cretaceous, when Site 801 was $5^{\circ}$ to $10^{\circ}$ south of the equator, finely laminated to massive radiolarite of Unit IV was deposited. By the middle Cretaceous, when Site 801 was as much as $16^{\circ} \mathrm{S}$, pelagic and biogenic accumulation patterns were masked by the influx of volcaniclastic turbidites, however relatively high accumulation rates are inferred from pelagic radiolarite beds preserved between turbidite beds. When Site 801 migrated north of the equator during the Late Cretaceous, alternating pelagic clay and radiolarite may have accumulated, but poor drilling recovery prevents verification of this hypothesis. Although the nature of bedding is not certain, accumulation rates were low and the unit contains more clay than units deposited at similar latitudes south of the equator. The Cretaceous deposits from Leg 129 suggest that productivity was higher in the southern part of equatorial divergence zone than the northern part; also the southern part of the zone was apparently greater in breadth.

\section{Tertiary}

When Site 802 was in the northern part of the equatorial zone in the early Tertiary, chalk turbidites of Unit III were deposited. These 
Table 5. Silica contents (in percent) of samples from Site 801, Leg 129.

\begin{tabular}{|c|c|c|c|c|c|c|c|c|c|}
\hline \multirow[b]{2}{*}{ Sample (cm) } & \multirow[b]{2}{*}{$\begin{array}{l}\text { Depth } \\
\text { (mbsf) }\end{array}$} & \multirow[b]{2}{*}{ Unit } & \multicolumn{4}{|c|}{ Percentage of sample } & \multicolumn{3}{|c|}{ Percentage of total silica } \\
\hline & & & $\begin{array}{l}\text { Total } \\
\mathrm{SiO}_{2}\end{array}$ & $\begin{array}{c}\text { Biogenic } \\
\mathrm{SiO}_{2}\end{array}$ & $\begin{array}{l}\text { Hydrothermal } \\
\mathrm{SiO}_{2}\end{array}$ & $\begin{array}{c}\text { Detrital } \\
\mathrm{SiO}_{2}\end{array}$ & $\begin{array}{c}\text { Biogenic } \\
\mathrm{SiO}_{2}\end{array}$ & $\begin{array}{l}\text { Hydrothermal } \\
\mathrm{SiO}_{2}\end{array}$ & $\begin{array}{c}\text { Detrital } \\
\mathrm{SiO}_{2}\end{array}$ \\
\hline \multicolumn{10}{|l|}{ 129-801A- } \\
\hline 7R-CC, 1 & 60.4 & II & 90.8 & 84.5 & 0.0 & 6.3 & 93.1 & 0.0 & 6.9 \\
\hline $8 \mathrm{R}, 1,1-3$ & 60.6 & II & 96.7 & 95.4 & 0.0 & 1.3 & 98.7 & 0.0 & 1.3 \\
\hline $9 \mathrm{R}-1,0-3$ & 70.2 & II & 83.9 & 72.7 & 0.0 & 11.2 & 86.6 & 0.0 & 13.4 \\
\hline $10 \mathrm{R}-1,0-5$ & 79.5 & II & 89.8 & 84.5 & 0.0 & 5.3 & 94.0 & 0.0 & 6.0 \\
\hline $10 \mathrm{R}-1,11$ & 79.6 & III & 90.5 & 83.6 & 0.0 & 6.9 & 92.3 & 0.0 & 7.7 \\
\hline $12 \mathrm{R}-1,22-25$ & 99.0 & II & 76.3 & 58.3 & 0.0 & 18.0 & 76.5 & 0.0 & 23.5 \\
\hline $80-100 \mathrm{M}$ & 100.0 & II & 82.8 & 71.2 & 0.0 & 11.6 & 86.0 & 0.0 & 14.0 \\
\hline $13 \mathrm{R}-1,21-26$ & 108.7 & II & 84.1 & 72.9 & 0.0 & 11.2 & 86.7 & 0.0 & 13.3 \\
\hline $14 R-1,26-28$ & 118.5 & II & 86.0 & 77.2 & 0.0 & 8.8 & 89.7 & 0.0 & 10.3 \\
\hline $15 R-1,24-26$ & 128.1 & III & 79.6 & 64.9 & 1.8 & 12.8 & 81.6 & 2.3 & 16.1 \\
\hline $16 \mathrm{R}-1,135-138$ & 139.0 & III & 75.4 & 58.8 & 1.1 & 15.5 & 77.9 & 1.4 & 20.6 \\
\hline $17 \mathrm{R}-1,28-30$ & 147.5 & III & 78.9 & 64.4 & 0.9 & 13.5 & 81.7 & 1.2 & 17.1 \\
\hline $18 \mathrm{R}-2,14-17$ & 158.6 & III & 76.9 & 60.9 & 0.9 & 15.1 & 79.2 & 1.2 & 19.6 \\
\hline 19R-CC, $12-16$ & 176.3 & III & 82.9 & 73.1 & 1.1 & 8.7 & 88.1 & 1.4 & 10.5 \\
\hline 20R-1, 8-12 & 176.5 & III & 88.6 & 82.4 & 0.6 & 5.7 & 93.0 & 0.6 & 6.4 \\
\hline \multicolumn{10}{|l|}{$129-801 \mathrm{~B}-$} \\
\hline $8 R-2,60-63$ & 254.8 & III & 89.5 & 83.6 & 0.1 & 5.8 & 93.4 & 0.1 & 6.5 \\
\hline $10 \mathrm{R}-1,70-73$ & 272.7 & III & 58.0 & 25.8 & 5.3 & 26.9 & 44.5 & 9.2 & 46.3 \\
\hline IIR-1, 31-36 & 282.0 & III & 77.1 & 58.9 & 0.7 & 17.6 & 76.3 & 0.9 & 22.8 \\
\hline $12 \mathrm{R}-1,64-70$ & 292.0 & III & 77.4 & 59.1 & 6.0 & 12.3 & 76.3 & 7.8 & 15.9 \\
\hline $14 \mathrm{R}-1,24$ & 310.5 & IV & 82.5 & 66.7 & 0.0 & 15.8 & 80.8 & 0.0 & 19.2 \\
\hline $14 \mathrm{R}-1,52-57$ & 310.8 & IV & 85.2 & 74.5 & 0.0 & 10.7 & 87.5 & 0.0 & 12.5 \\
\hline $15 \mathrm{R}-1,19-20$ & 319.9 & IV & 82.9 & 69.1 & 0.0 & 13.8 & 83.4 & 0.0 & 16.6 \\
\hline $16 \mathrm{R}-1,40-43$ & 329.6 & IV & 93.1 & 89.1 & 0.0 & 4.0 & 95.7 & 0.0 & 4.3 \\
\hline $17 \mathrm{R}-1,34-36$ & 338.9 & IV & 92.4 & 87.7 & 0.0 & 4.7 & 94.9 & 0.0 & 5.1 \\
\hline $18 \mathrm{R}-1,24$ & 348.0 & IV & 85.4 & 73.2 & 0.0 & 12.2 & 85.7 & 0.0 & 14.3 \\
\hline $18 \mathrm{R}-1,37-40$ & 348.2 & IV & 91.0 & 85.2 & 0.0 & 5.8 & 93.6 & 0.0 & 6.4 \\
\hline $19 \mathrm{R}-1,24-26$ & 357.5 & IV & 95.5 & 93.7 & 0.0 & 1.8 & 98.1 & 0.0 & 1.9 \\
\hline $20 \mathrm{R}-1,23-26$ & 366.7 & IV & 91.8 & 86.7 & 0.0 & 5.1 & 94.4 & 0.0 & 5.6 \\
\hline 2 IR-1, 12-13 & 375.8 & IV & 92.8 & 86.8 & 1.5 & 4.5 & 93.5 & 1.6 & 4.8 \\
\hline $24 \mathrm{R}-1,54$ & 393.1 & IV & 85.3 & 74.6 & 0.1 & 10.6 & 87.5 & 0.2 & 12.4 \\
\hline $24 R-1,69-73$ & 393.3 & IV & 90.7 & 84.2 & 0.0 & 6.5 & 92.9 & 0.0 & 7.1 \\
\hline $25 \mathrm{R}-1,1$ & 397.2 & IV & 85.9 & 74.6 & 0.1 & 11.2 & 86.8 & 0.1 & 13.1 \\
\hline $25 \mathrm{R}-1,49-53$ & 397.7 & IV & 84.7 & 72.6 & 0.0 & 12.1 & 85.7 & 0.0 & 14.3 \\
\hline $27 \mathrm{R}-1,30$ & 407.0 & IV & 96.8 & 95.6 & 0.2 & 1.0 & 98.7 & 0.3 & 1.0 \\
\hline $27 \mathrm{R}-1,104-107$ & 407.7 & IV & 93.7 & 90.3 & 0.0 & 3.4 & 96.3 & 0.0 & 3.6 \\
\hline $29 \mathrm{R}-1,17-19$ & 416.4 & IV & 92.7 & 88.2 & 0.0 & 4.5 & 95.2 & 0.0 & 4.8 \\
\hline $31 \mathrm{R}-1,18-20$ & 425.8 & IV & 92.8 & 88.3 & 0.0 & 4.5 & 95.1 & 0.0 & 4.9 \\
\hline $33 \mathrm{R}-1,10-14$ & 434.9 & IV & 68.7 & 38.3 & 9.7 & 20.6 & 55.8 & 14.2 & 30.0 \\
\hline $33 \mathrm{R}-1,43$ & 435.2 & IV & 81.4 & 64.2 & 2.3 & 14.9 & 78.9 & 2.8 & 18.2 \\
\hline $33 R-1,126-129$ & 436.1 & IV & 83.7 & 69.3 & 1.1 & 13.3 & 82.8 & 1.3 & 15.8 \\
\hline $33 \mathrm{R}-2,48$ & 436.8 & IV & 83.7 & 70.7 & 3.1 & 9.9 & 84.4 & 3.7 & 11.8 \\
\hline $35 \mathrm{R}-1,51-55$ & 444.8 & $\mathrm{~V}$ & 64.6 & 30.5 & 6.2 & 27.9 & 47.3 & 9.6 & 43.1 \\
\hline $35 \mathrm{R}-1,123-127$ & 445.5 & $\mathrm{v}$ & 74.5 & 49.8 & 7.5 & 17.2 & 66.9 & 10.1 & 23.0 \\
\hline $35 \mathrm{R}-2,120$ & 447.0 & V & 56.3 & 12.3 & 6.7 & 37.3 & 21.9 & 11.9 & 66.2 \\
\hline $35 R-2,140$ & 447.2 & V & 64.8 & 30.4 & 7.0 & 27.4 & 46.9 & 10.8 & 42.3 \\
\hline $35 \mathrm{R}-3,1$ & 447.3 & V & 66.7 & 34.2 & 4.8 & 27.7 & 51.3 & 7.1 & 41.6 \\
\hline $35 \mathrm{R}-3,19$ & 447.5 & V & 69.8 & 40.1 & 3.9 & 25.7 & 57.5 & 5.6 & 36.9 \\
\hline $37 \mathrm{R}-1,7-10$ & 453.6 & v & 91.8 & 84.9 & 4.8 & 2.0 & 92.5 & 5.3 & 2.2 \\
\hline $39 \mathrm{R}-1,4-7$ & 462.7 & VI & 94.8 & 90.4 & 1.9 & 2.4 & 95.4 & 2.0 & 2.6 \\
\hline \multicolumn{10}{|l|}{$129-801 \mathrm{C}-$} \\
\hline $4 \mathrm{R}-1,11-16$ & 521.8 & VI & 81.1 & 53.6 & 27.2 & 0.3 & 66.1 & 33.5 & 0.4 \\
\hline $5 R-4,11-16$ & 535.8 & VI & 11.4 & 3.9 & 5.9 & 1.5 & 34.6 & 52.1 & 13.3 \\
\hline
\end{tabular}

voluminous deposits have masked clues to depositional conditions at this location in the Tertiary. Background sedimentation at the equator consisted of pelagic clay with less than $10 \%$ siliceous or calcareous fauna and low accumulation rates. Sites 800 and 801 were north of the equatorial zone during the Tertiary, where sedimentation and accumulation rates were both extremely low, and pelagic clay was deposited.

\section{GEOCHEMISTRY OF LEG 129 SILICEOUS DEPOSITS}

Leg 129 sedimentary rocks were analyzed geochemically in order to characterize various types of siliceous deposits. Trends in element abundance were consistent between the three sites. Elements tested as key environmental indicators include $\mathrm{Si}, \mathrm{Fe}, \mathrm{Mn}, \mathrm{Mg}, \mathrm{Al}, \mathrm{B}, \mathrm{P}, \mathrm{Ba}$, 
Table 6. Silica contents (in percent) of samples from Site 802, Leg 129.

\begin{tabular}{|c|c|c|c|c|c|c|c|c|c|}
\hline \multirow[b]{2}{*}{ Sample $(\mathrm{cm})$} & \multirow[b]{2}{*}{$\begin{array}{l}\text { Depth } \\
\text { (mbsf) }\end{array}$} & \multirow[b]{2}{*}{ Unit } & \multicolumn{4}{|c|}{ Percentage of sample } & \multicolumn{3}{|c|}{ Percentage of total silica } \\
\hline & & & $\begin{array}{l}\text { Total } \\
\mathrm{SiO}_{2}\end{array}$ & $\begin{array}{l}\text { Biogenic } \\
\mathrm{SiO}_{2}\end{array}$ & $\begin{array}{l}\text { Hydrothermal } \\
\mathrm{SiO}_{2}\end{array}$ & $\begin{array}{l}\text { Detrital } \\
\mathrm{SiO}_{2}\end{array}$ & $\begin{array}{l}\text { Biogenic } \\
\mathrm{SiO}_{2}\end{array}$ & $\begin{array}{l}\text { Hydrothermal } \\
\mathrm{SiO}_{2}\end{array}$ & $\begin{array}{c}\text { Detrital } \\
\mathrm{SiO}_{2}\end{array}$ \\
\hline \multicolumn{10}{|l|}{$129-802 \mathrm{~A}-$} \\
\hline $33 \mathrm{R}-1,116-120$ & 294.0 & III & 45.5 & 42.1 & 0.0 & 3.4 & 92.5 & 0.0 & 7.5 \\
\hline $34 \mathrm{R}-1,128-132$ & 303.6 & III & 95.8 & 95.2 & 0.0 & 0.6 & 99.3 & 0.0 & 0.7 \\
\hline $35 \mathrm{R}-\mathrm{CC}, 0-4$ & 320.5 & III & 94.8 & 93.2 & 0.0 & 1.6 & 98.4 & 0.0 & 1.6 \\
\hline $37 \mathrm{R}-1,11-15$ & 330.0 & IV & 88.9 & 86.3 & 0.0 & 2.6 & 97.0 & 0.0 & 3.0 \\
\hline $38 \mathrm{R}-\mathrm{CC}, 12-15$ & 348.6 & IV & 65.4 & 43.6 & 0.5 & 21.3 & 66.6 & 0.8 & 32.5 \\
\hline $39 \mathrm{R}-1,10-15$ & 348.8 & IV & 70.0 & 53.8 & 1.2 & 15.0 & 76.8 & 1.7 & 21.5 \\
\hline $43 \mathrm{R}-1,75-78$ & 382.9 & V & 77.8 & 62.2 & 0.0 & 15.6 & 80.0 & 0.0 & 20.0 \\
\hline $52 \mathrm{R}-2,125-130$ & 462.6 & VI & 73.2 & 49.8 & 0.0 & 23.4 & 68.1 & 0.0 & 31.9 \\
\hline $55 \mathrm{R}-1,138-141$ & 489.3 & VII & 76.3 & 56.9 & 0.0 & 19.4 & 74.5 & 0.0 & 25.5 \\
\hline $56 \mathrm{R}-1,43-47$ & 497.5 & VIII & 70.7 & 44.5 & 0.0 & 26.2 & 63.0 & 0.0 & 37.0 \\
\hline $56 \mathrm{R}-2,88-92$ & 499.5 & VIII & 78.8 & 61.9 & 4.6 & 12.2 & 78.6 & 5.9 & 15.5 \\
\hline
\end{tabular}

Notes: Ratios and equations from Heath and Dymond (1977) and Bishoff et al. (1979). Detrital $\mathrm{SiO}_{2} \%=3.3\left(\mathrm{Al}_{2} \mathrm{O}_{3} \%\right)$; hydrothermal $\mathrm{SiO}_{2} \%=1.74\left[\left(\mathrm{Fe}_{2} \mathrm{O}_{3}-0.75 \mathrm{Al}_{2} \mathrm{O}_{3}\right)-0.32 \mathrm{MnO}\right] ;$ biogenic $\mathrm{SiO}_{2} \%=$ total $\mathrm{SiO} 2 \%$ - detrital $\mathrm{SiO}_{2} \%$ - hydrothermal $\mathrm{SiO}_{2} \%$.

$\mathrm{Cu}, \mathrm{La}$, and $\mathrm{Ce}$. Because some elements are characteristic of more than one depositional environment, element ratios and partitioning equations have been derived to discriminate between environments (Bishoff et al., 1979, Leinen and Stakes, 1979; Leinen, 1981; Leinen and Pisias, 1982). Aluminum to metal ratios plotted according to defined fields in various diagrams (Bostrom, 1973, Karpoff et al., 1988; Karpoff, 1989) help to determine detrital and metalliferous sources of the sediments. A copper-barium plot discriminates between biogenic and authigenic sources (Karl, 1982). Finally, rare earth element (REE) patterns are compared in order to identify sedimentary sources and depositional trends.

\section{Methods of Analysis}

One hundred and one samples of siliceous rocks were chosen from Sites 800,801 , and 802 . These samples were selected to represent background sedimentation as well as depositional episodes, such as high productivity events or turbidite events. For example, in the turbidite units, both the fine-grained tops of turbidites and the pelagic interval between turbidites were sampled for purposes of comparison. In the alternating chert/shale units, both lithologies were sampled. Statistically, however, each unit is represented overwhelmingly by pelagic deposits in this study. Poor recovery in general at Leg 129 sites, and in particular for siliceous lithologies, limited our ability to adequately sample every unit.

Samples studied each weighed approximately $15 \mathrm{~g}$ and were ground to -100 mesh in a tungsten carbide mill. Tungsten carbide mills are known to contaminate samples in $\mathrm{Co}, \mathrm{Nb}, \mathrm{Ta}$, and $\mathrm{W}$; this crushing equipment was chosen because these elements were considered less important than contaminating elements from other means of crushing. After crushing the samples were divided into three splits. One split was analyzed nondestructively for minor elements by X-ray spectroscopy, and by X-ray fluorescence for major elements (Appendix Tables A1-A3 and B1-B3). The precision of the minor element analyses is approximately $10 \%$, and of the major elements is $1 \%-2 \%$. The second split was analyzed for Boron by quantitative emission spectroscopy. Rare earth element compositions were determined on the third split by induced neutron activation analysis (Appendix Tables $\mathrm{C} 1-\mathrm{C} 3$ ). The samples were irradiated for $7 \mathrm{hr}$ in the TRIGA reactor at the U.S. Geological Survey in Denver, and counted 4 times over 8 weeks.

Thirty additional samples of siliceous rocks were analyzed for major and minor elements by microprobe at the University of Strasbourg, France (Appendix Tables D1 and D2). The precision of these analyses is about $2 \%$ for major elements and $10 \%$ for minor elements, which is comparable to the analyses performed in the U.S. Geological Survey laboratories. Consequently these data were plotted together where appropriate.

\section{Results}

\section{Silica}

The two main sources of silica in the ocean are detrital aluminosilicates (both terrigenous and volcaniclastic) and biogenic tests (Bostrom et al., 1974; Heath, 1974; Berger, 1976). Alteration of clays and volcanic glass, and hydrothermal emanations also contribute minor amounts of silica (Rona et al., 1980). Since the ocean is $98 \%$ undersaturated with respect to silica (Berger, 1976), biogenic siliceous deposits only accumulate under areas with high rates of deposition. High rates of deposition are controlled by the availability of nutrients, which are brought up to the photic zone in regions of current shear, such as the equatorial divergence, or where winds and currents impinge on continental margins (Kennett, 1982). Siliceous deposits in the modern Pacific Ocean accumulate near the equator, at high latitudes, and along the continental margins (Berger, 1976; Keene, 1976; Jenkyns, 1978). At the equator, productivity is ultimately controlled mainly by climate, because temperature contrast between the poles and equator during cool climates drives stronger winds and currents. During times of low productivity, only pelagic clay accumulates. The cyclicity of pelagic clay and siliceous deposits on a centimeter scale has been attributed cyclic climatic variations, or Milankovitch cycles (RCCG, 1986; Rea et al., 1991).

The siliceous deposits at Sites 800,801 , and 802 were deposited between $5^{\circ} \mathrm{N}$ and $15^{\circ} \mathrm{S}$ of the equator, and are dominantly biogenic. The central Pacific low-latitude paleo-location of these sites, with winds from the east, resulted in a negligible contribution of terrigenous material to this area during deposition of the sediments sampled for this study. Illite and quartz grains signify terrigenous contributions to siliceous deposits; the scarcity of illite and the lack of quartz grains in Leg 129 deposits suggests most of the detrital sediments are volcaniclastic. Interbedded volcaniclastic turbidites indicate an intermittent volcanic source. Reworking of volcanic detritus by bottom currents between volcanic episodes may have intercalated volcanic material with the pelagic deposits. There was probably some contribution of silica from alteration of volcanic-derived clay minerals and glass in the volcaniclastic turbidite sections. At the base of Site 801, there is hydrothermal silica.

Partitioning ratios for elements representing the above sediment sources were used to calculate relative proportions of these sources. Partitioning of silica, based on ratios and equations from Heath and Dymond (1977) and Bishoff et al. (1979) (Tables 4, 5, and 6), shows 
ODP SITE 800 (Fe\% (XRF AND MICROPROBE))

ODP SITE 801 (Fe\% (XRF AND MICROPROBE))
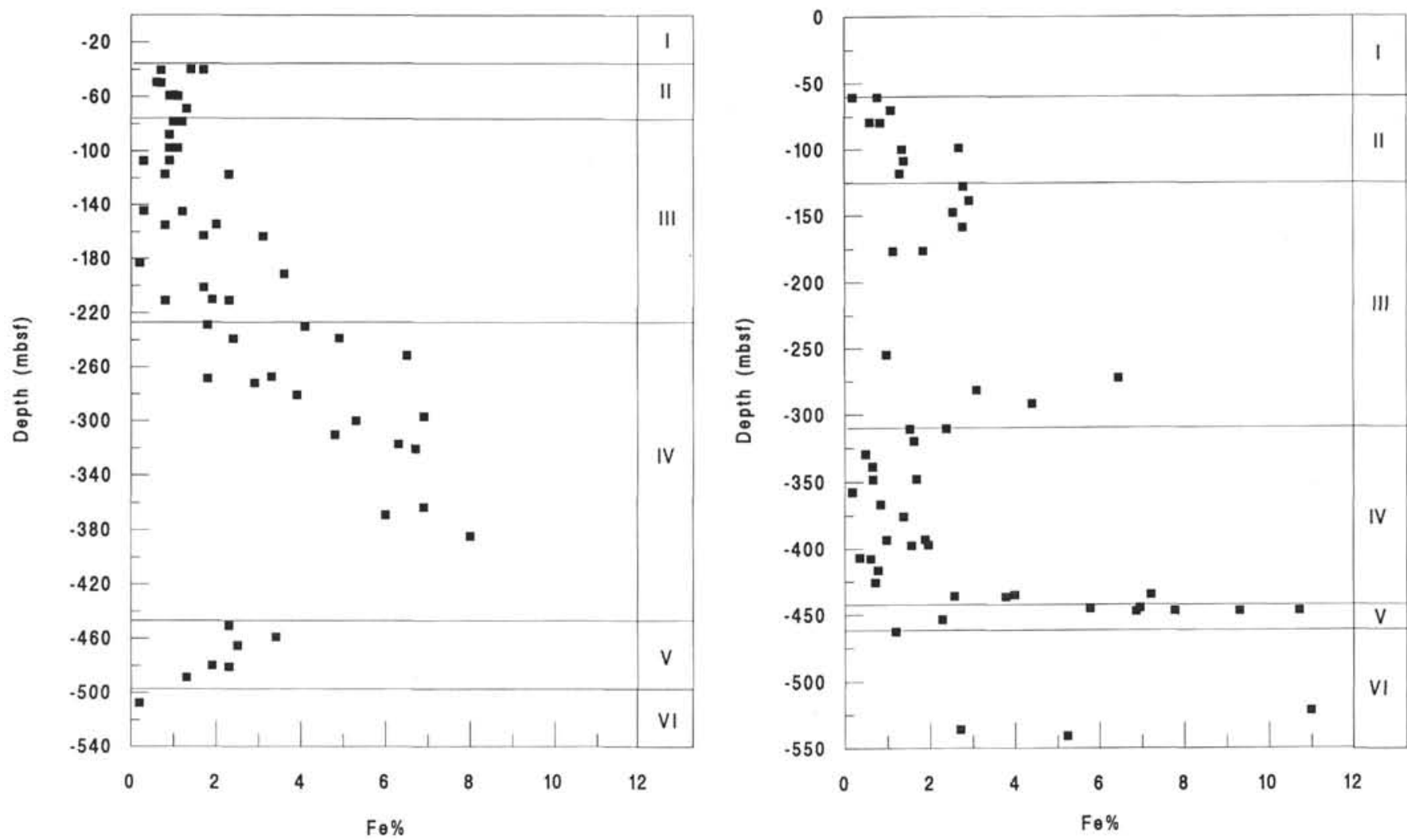

ODP SITE 802 (Fe\% (XRF))

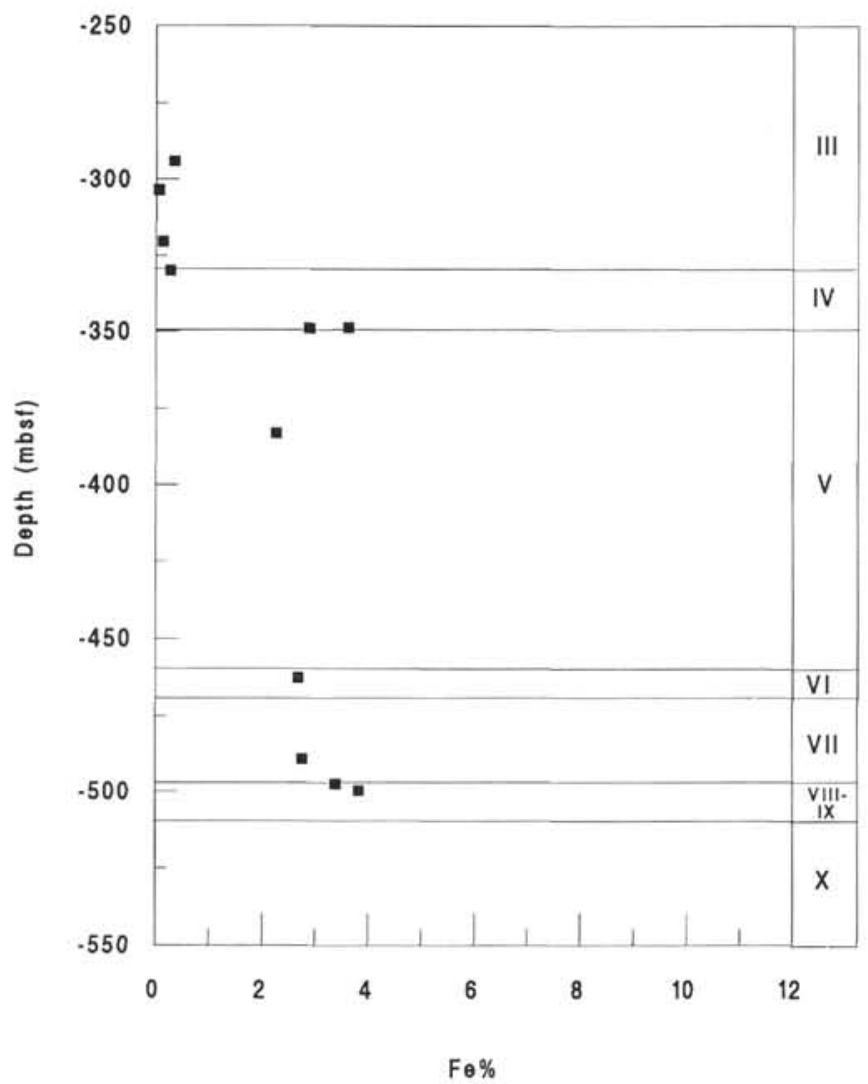

Figure 4. Iron contents of samples from Leg 129. 
ODP SITE 800 (Mn\% (XRF AND MICROPROBE))

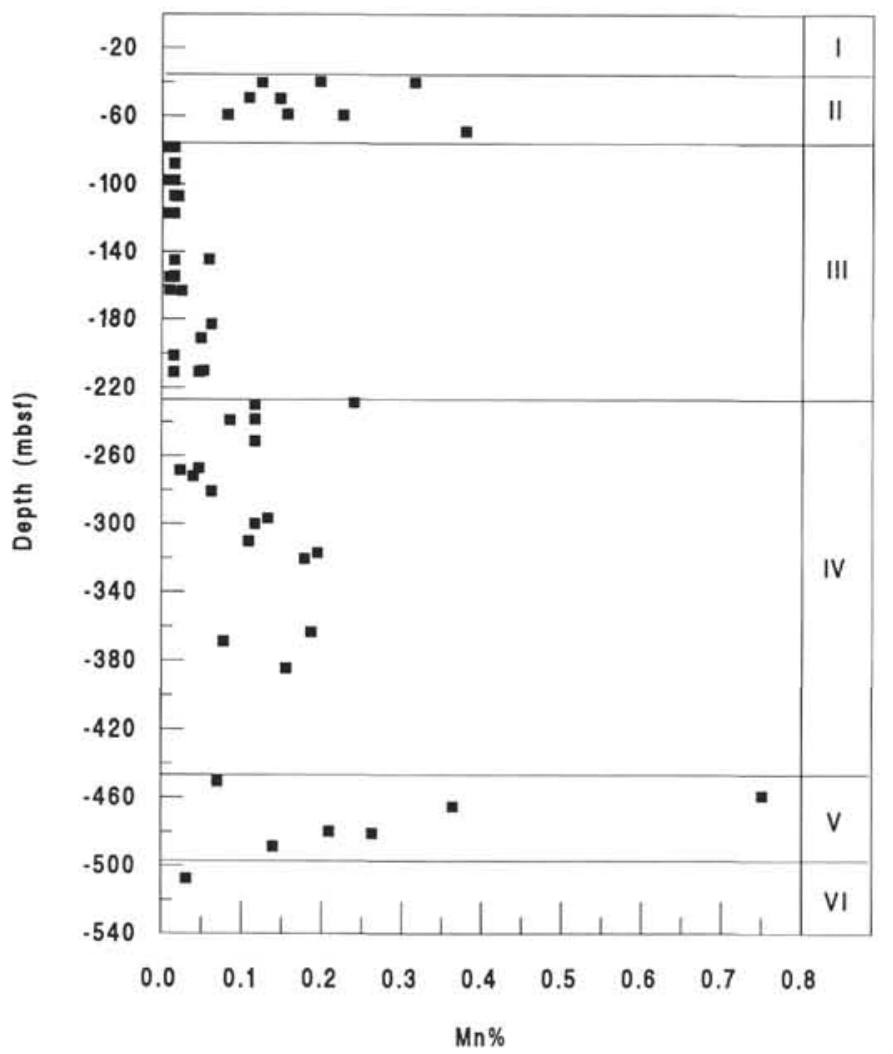

ODP SITE 801 (Mn\% (XRF AND MICROPROBE))

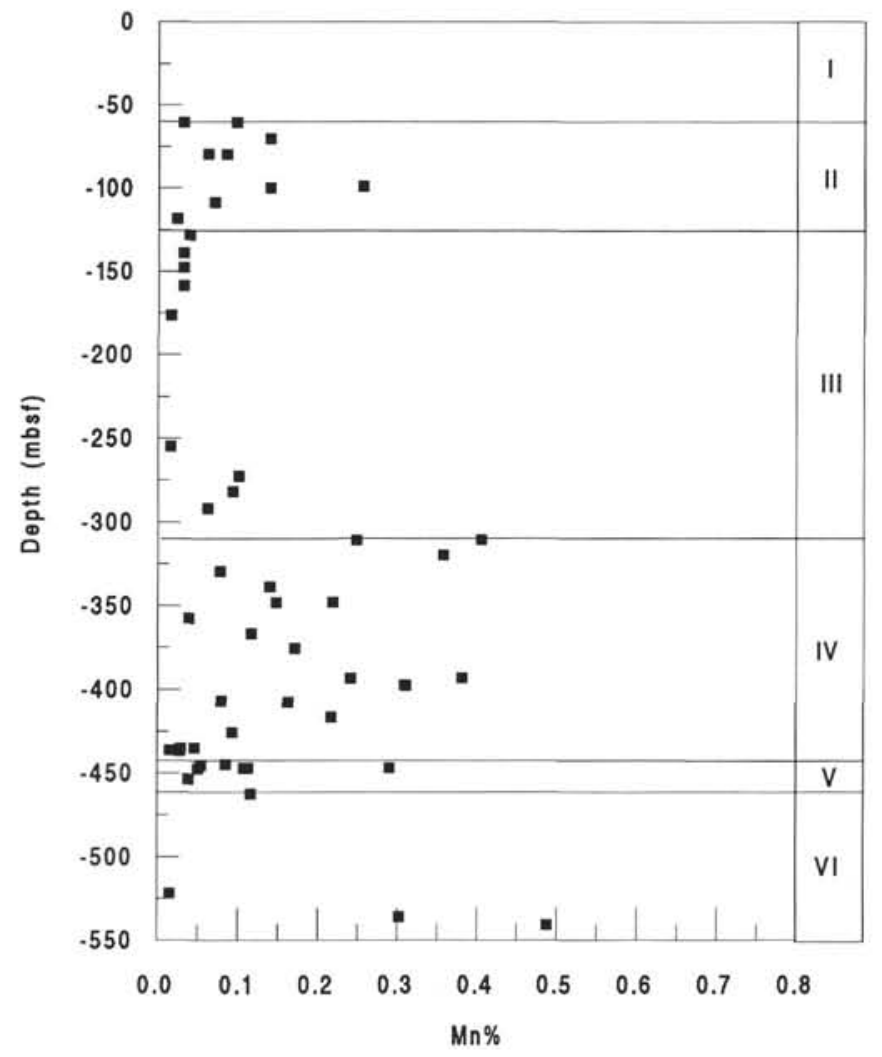

ODP SITE 802 (Mn\% (XRF))

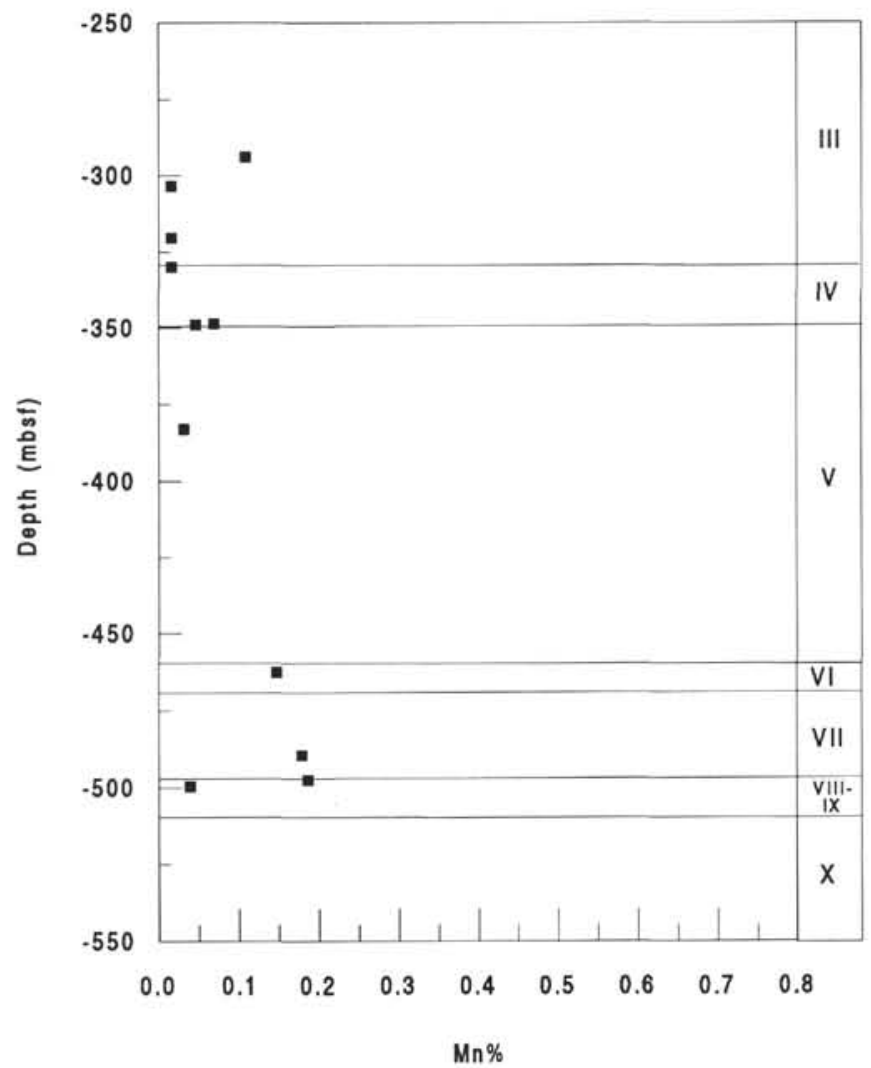

Figure 5. Manganese contents of samples from Leg 129. 
ODP SITE 800 (Mg\% (XRF AND MICROPROBE))

ODP SITE 801 (Mg\% (XRF AND MICROPROBE))
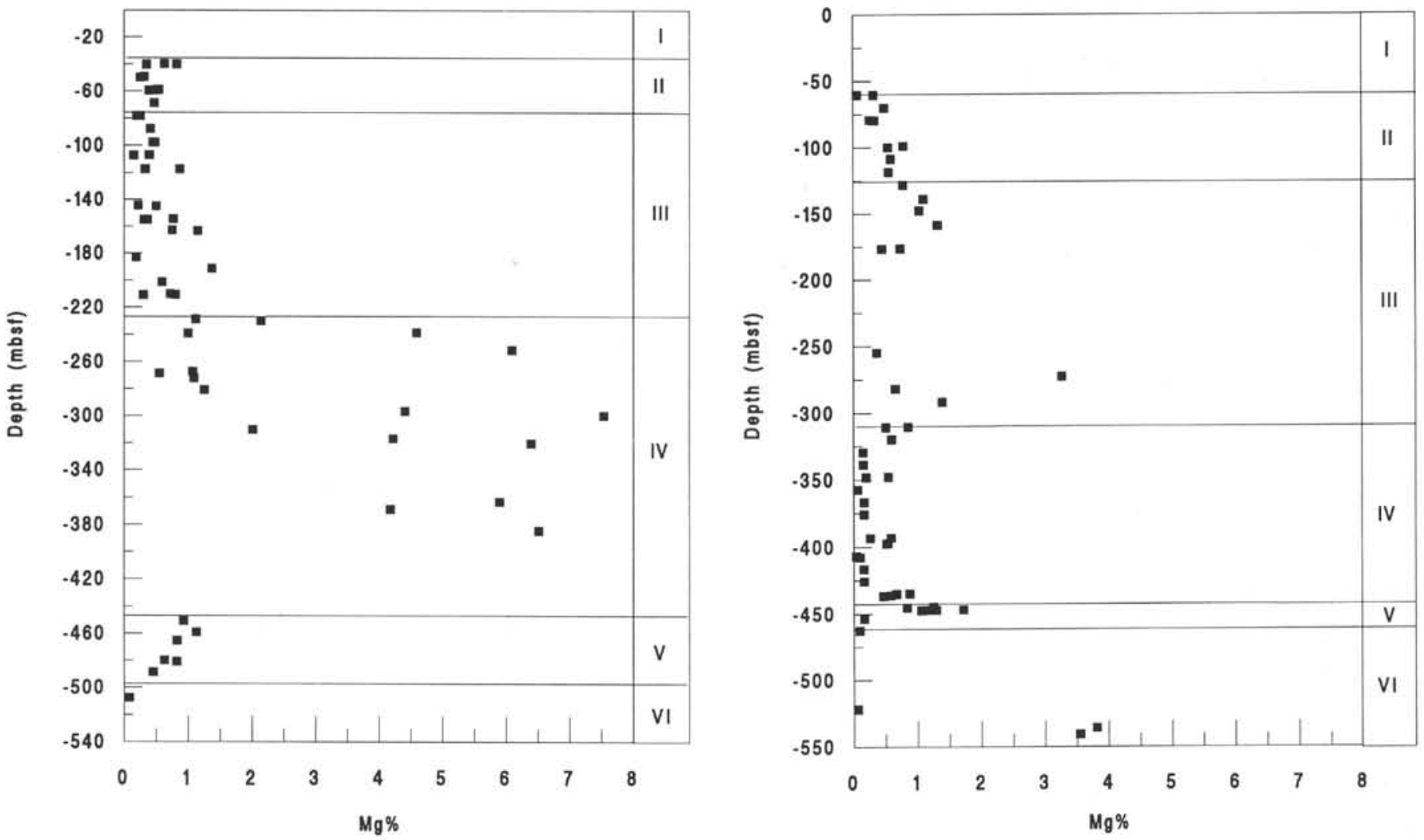

ODP SITE 802 (Mg\% (XRF))

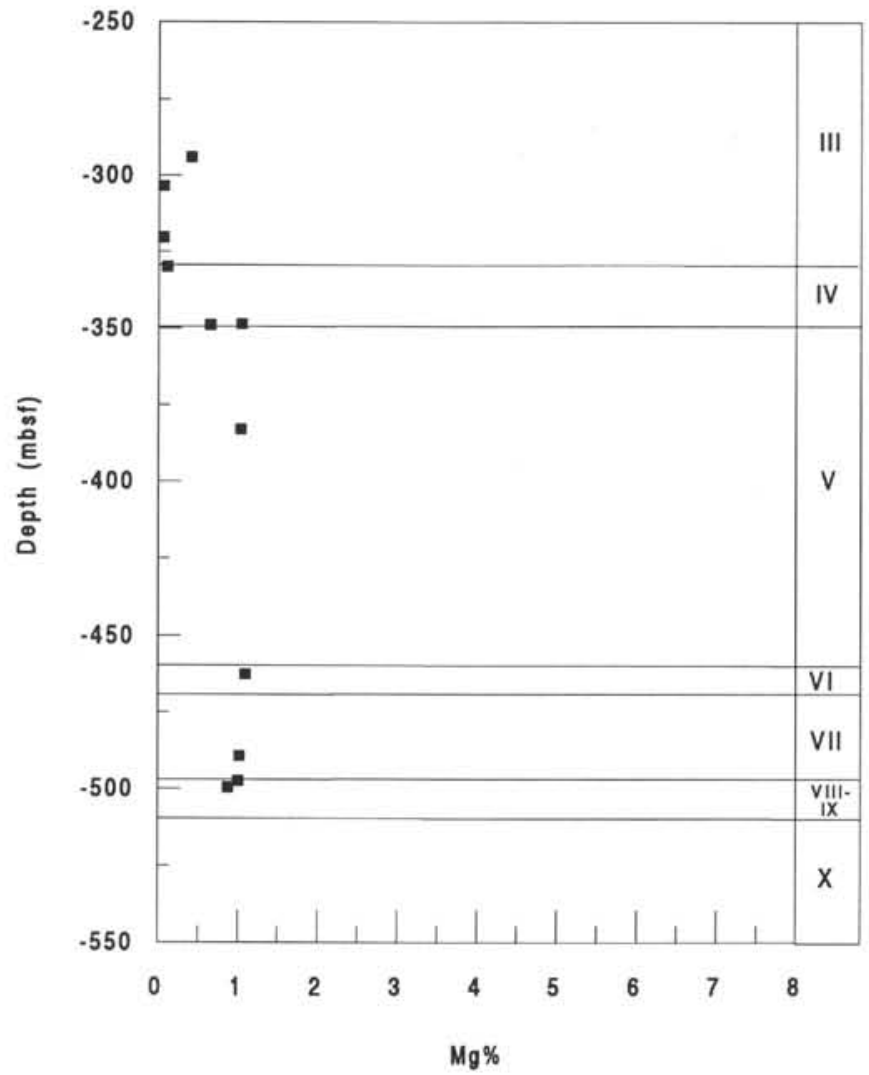

Figure 6. Magnesium contents of samples from Leg 129. 
ODP SITE 800 (AI\% (XRF AND MICROPROBE))

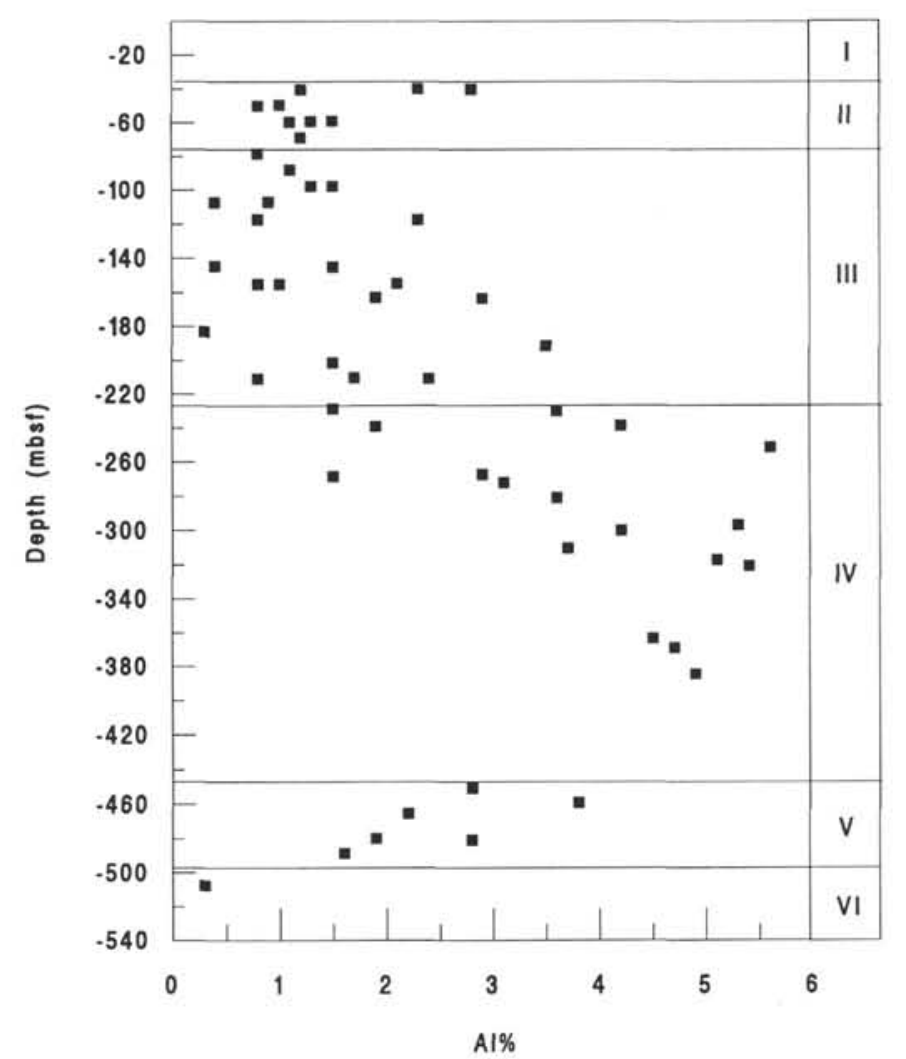

ODP SITE 801 (AI\% (XRF AND MICROPROBE))

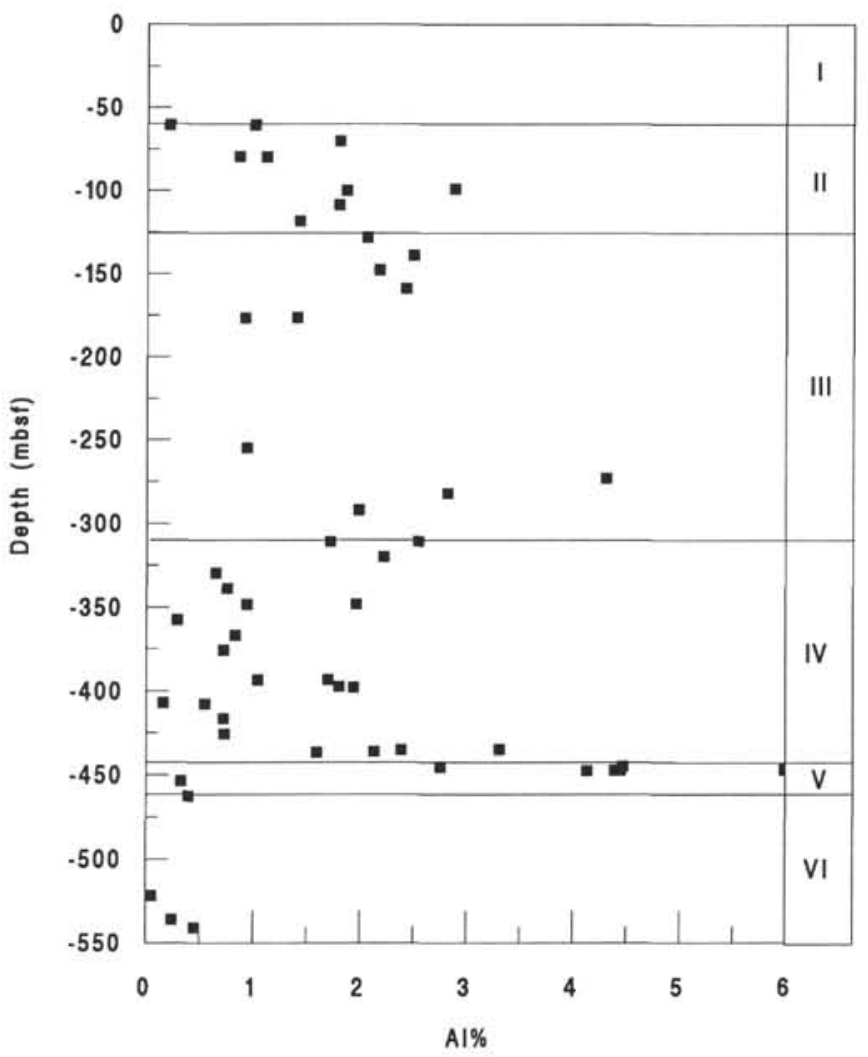

AI\%

ODP SITE 802 (AI\% (XRF))

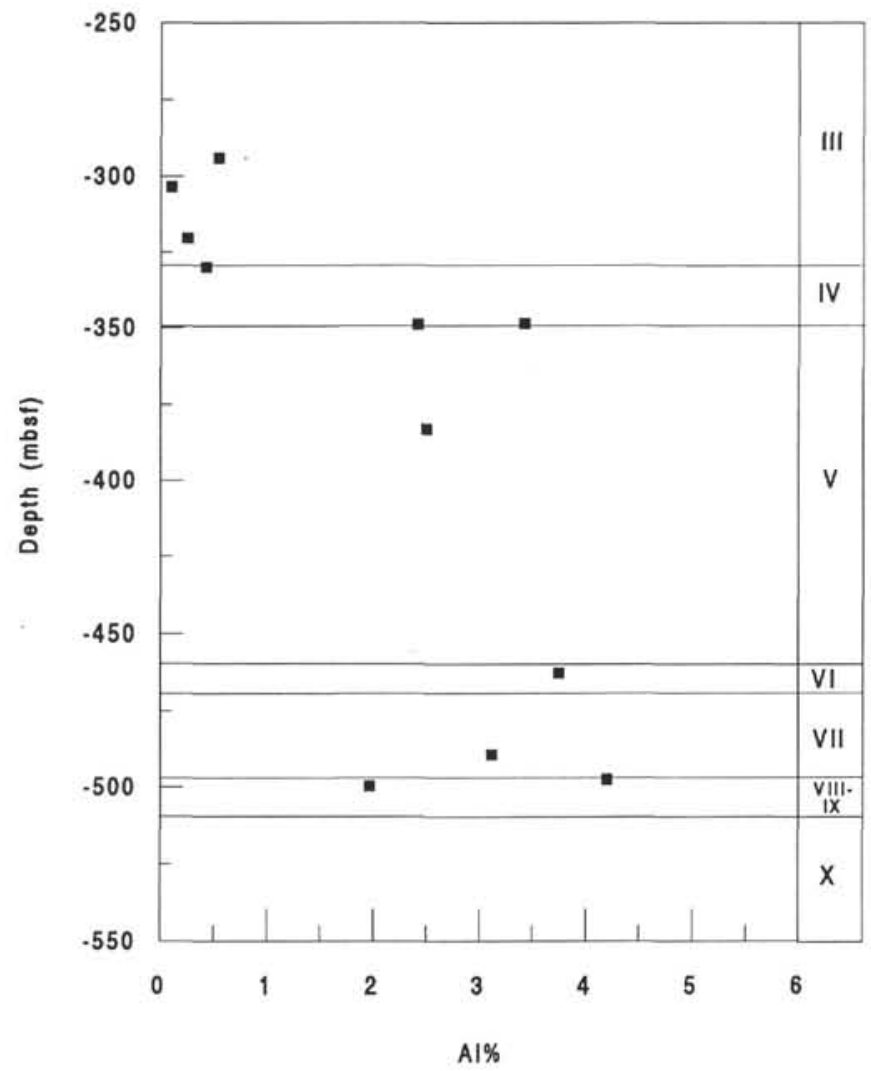

Figure 7. Aluminum contents of samples from Leg 129. 
ODP SITE 800 (P\% (XRF))

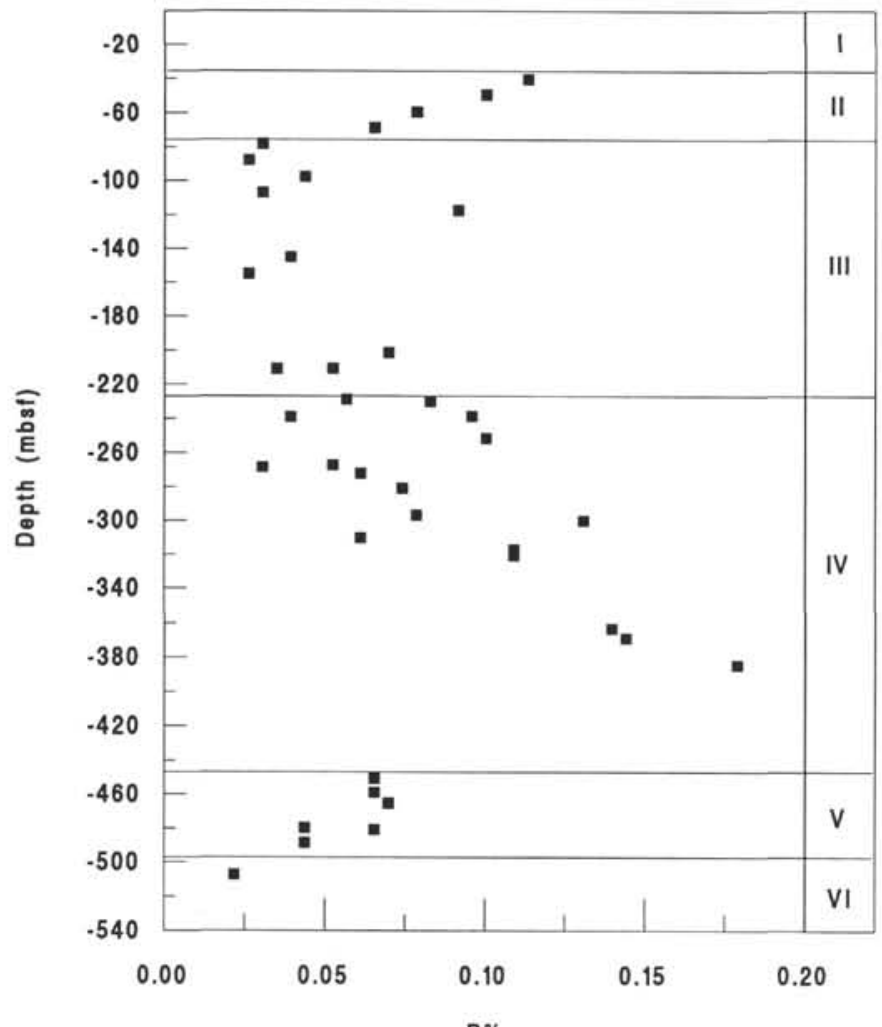

ODP SITE 801 (P\% (XRF))

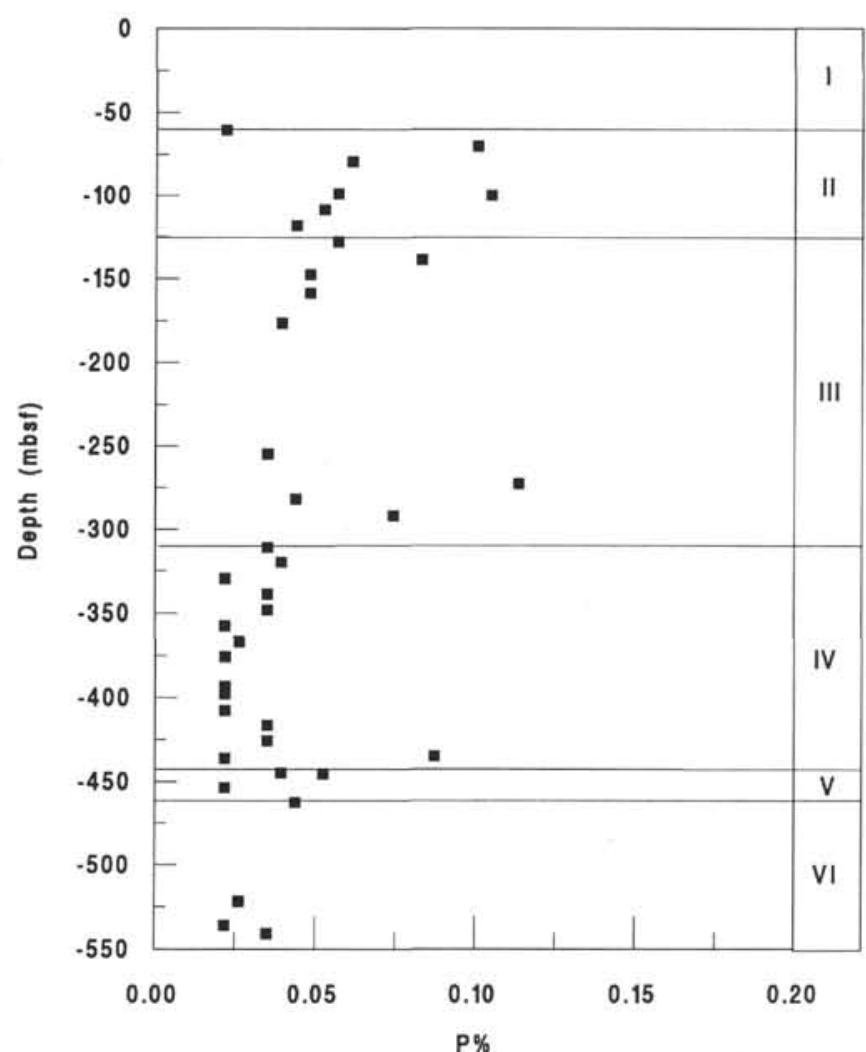

ODP SITE 802 (P\% (XRF))

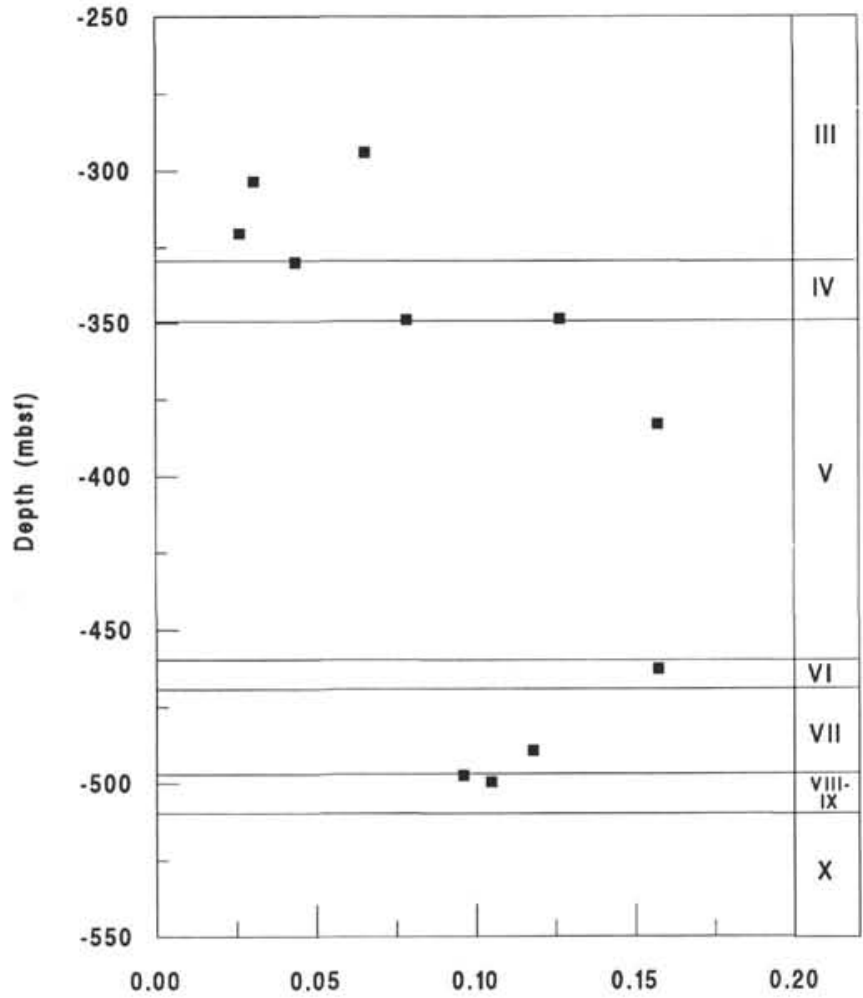

$\mathrm{P} \%$

Figure 8. Phosphorous contents of samples from Leg 129. 
ODP SITE 800 (B ppm (MASS SPEC.))

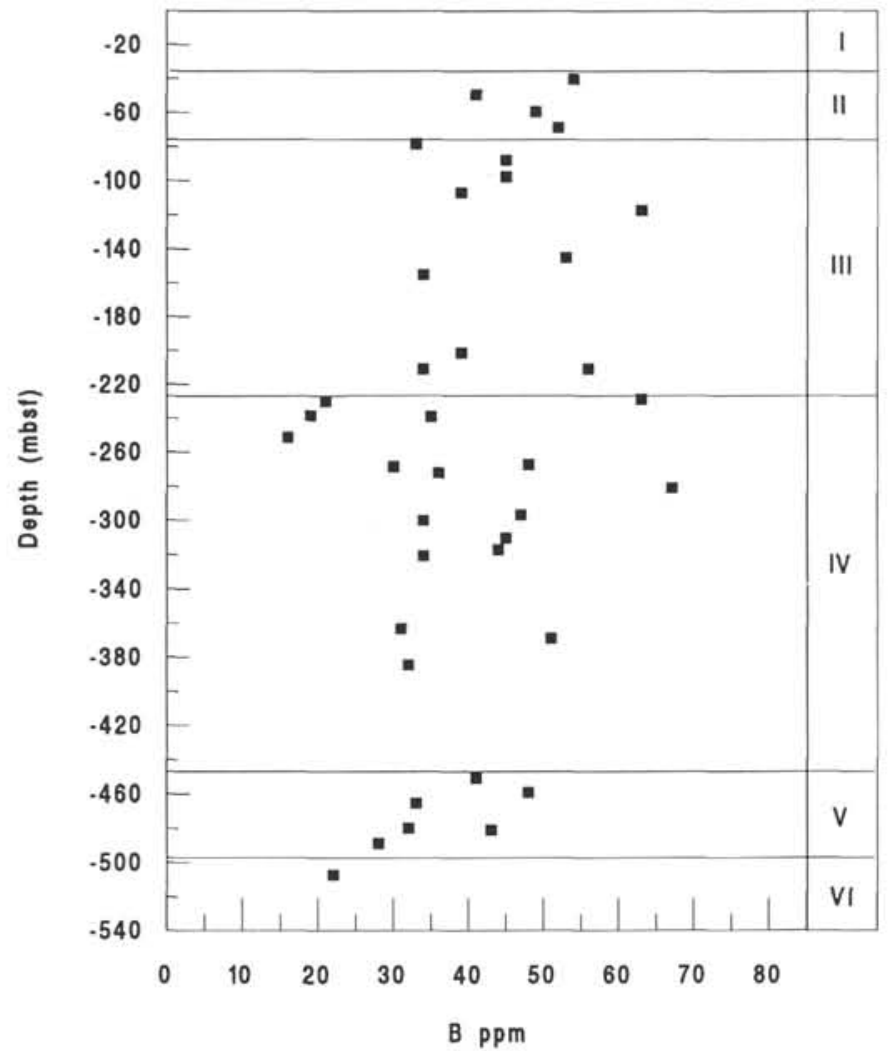

ODP SITE 801 (B ppm (MASS SPEC.))

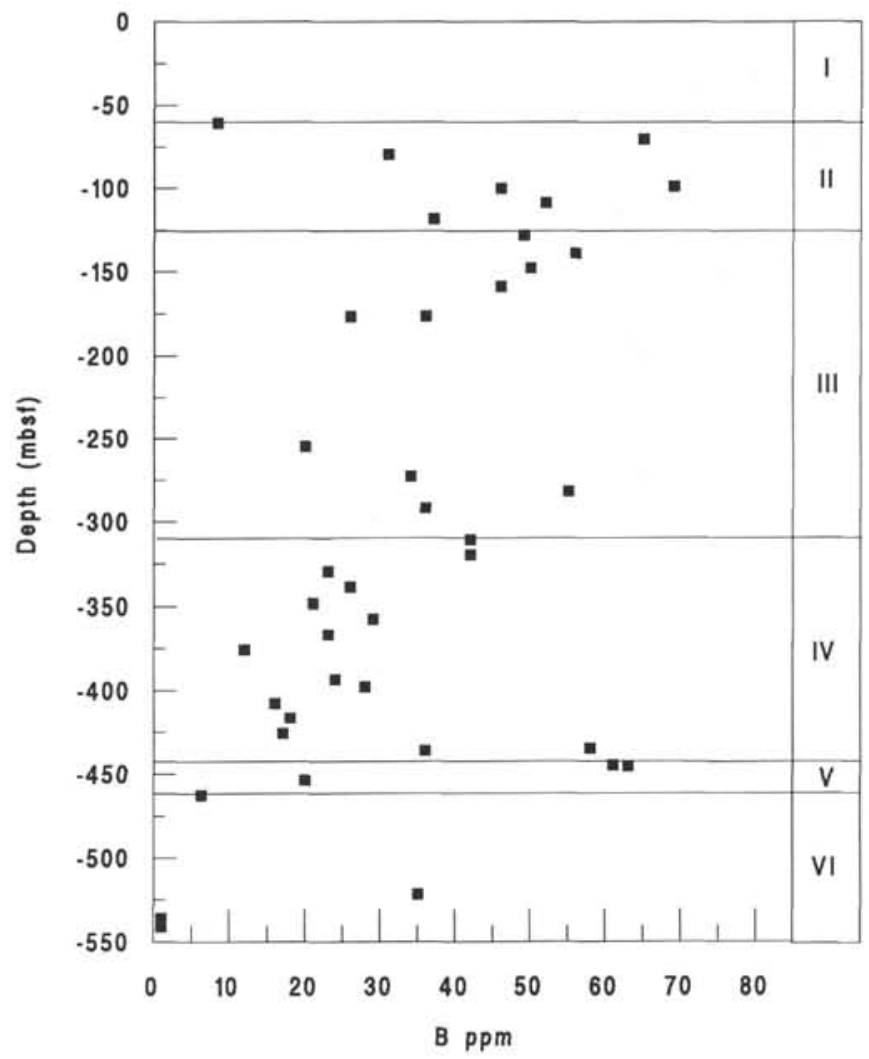

ODP SITE 802 (B ppm (MASS SPEC.))

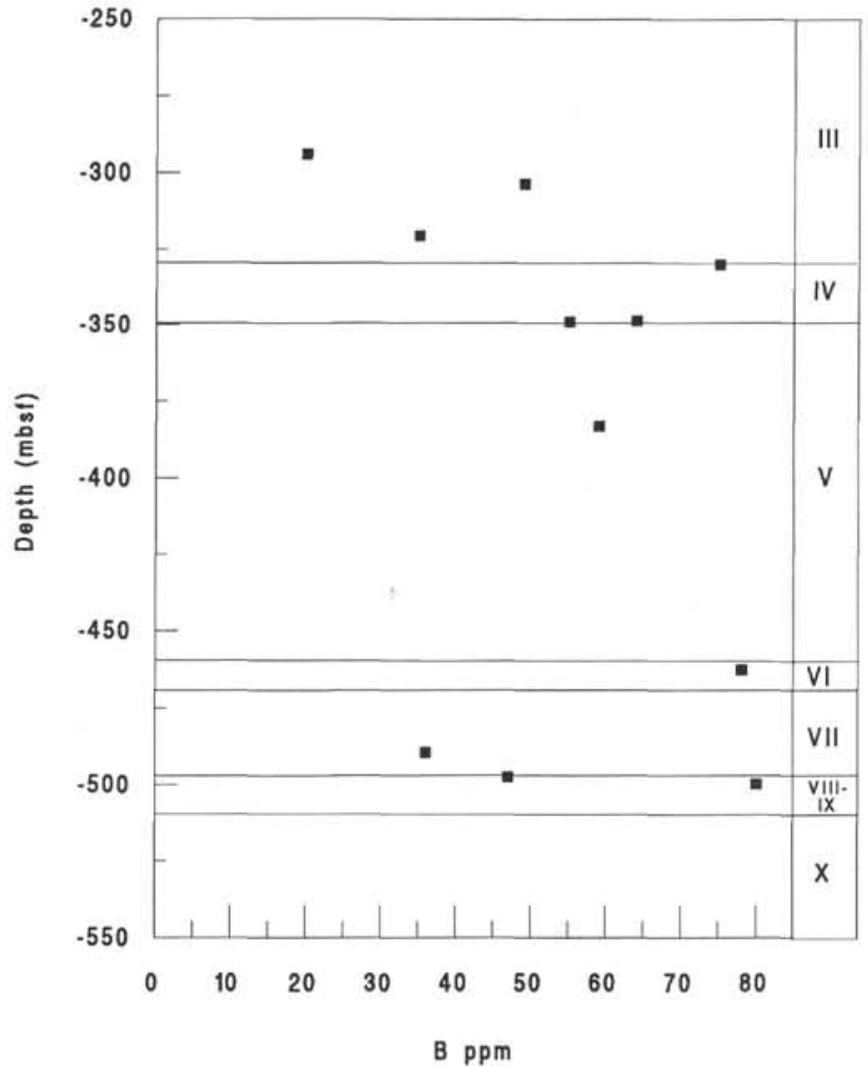

Figure 9. Boron contents of samples from Leg 129. 
ODP SITE 800 (La ppm (INAA))

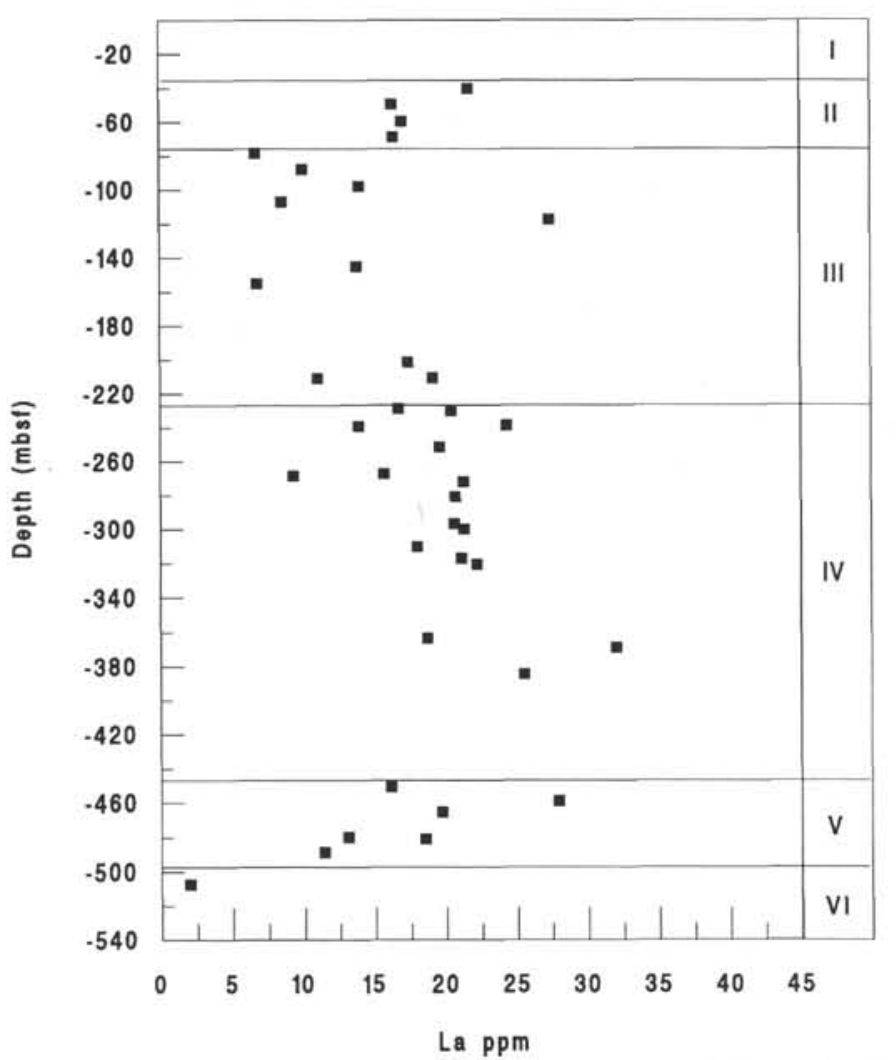

ODP SITE 801 (La ppm (INAA))

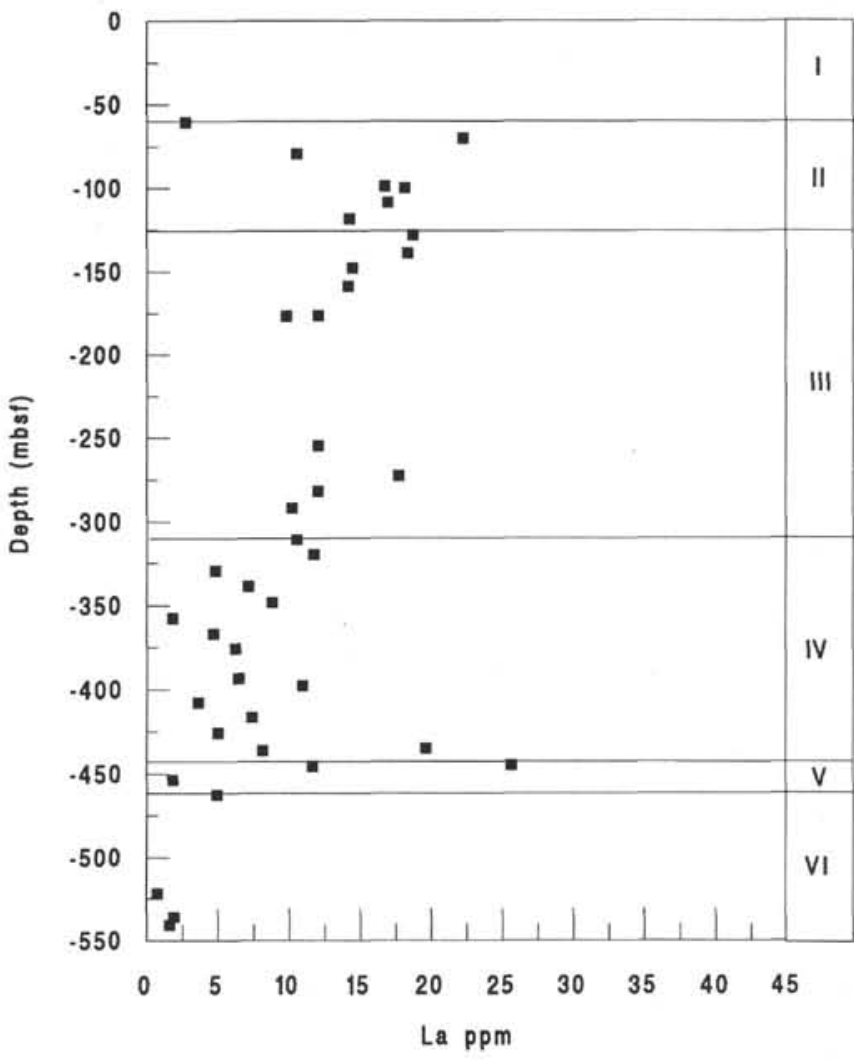

ODP SITE 802 (La ppm (INAA))

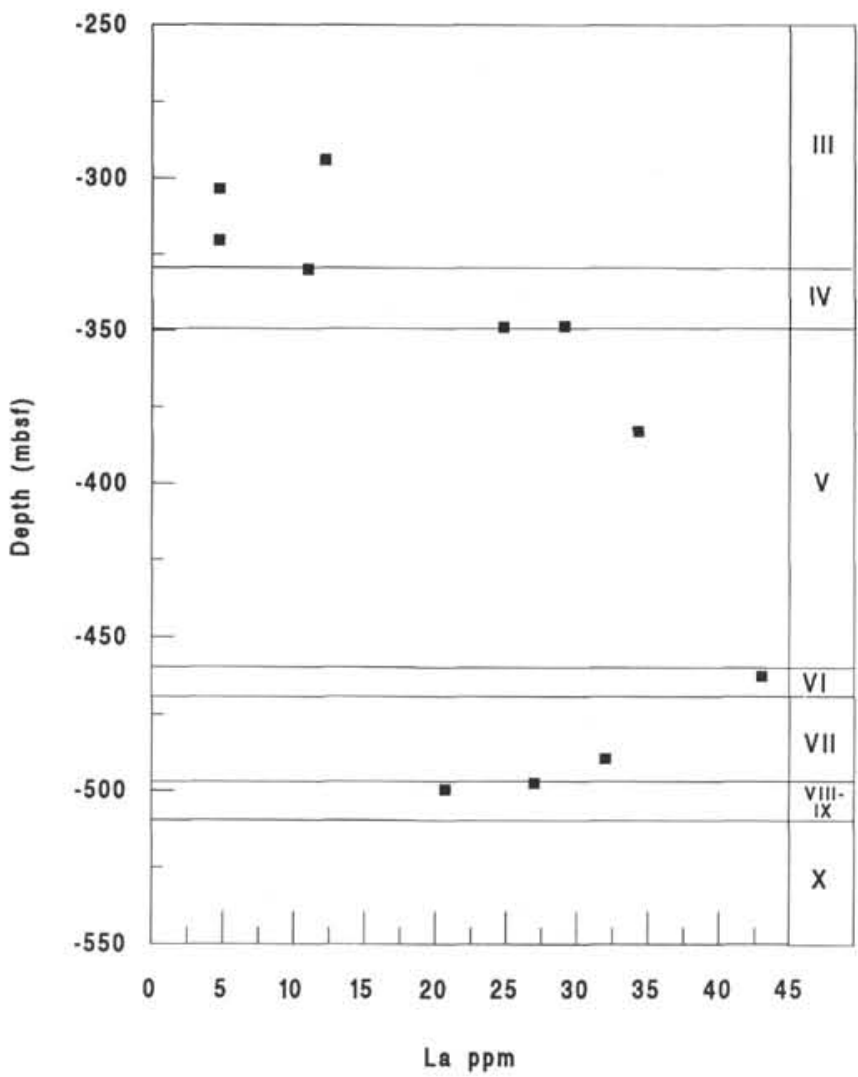

Figure 10. Lanthanum contents of samples from Leg 129. 
that the silica at all three sites is predominantly biogenic, with a high (volcaniclastic) detrital component in the samples from the turbidite units. Thin section observations, microprobe, and XRD analyses indicate that the clay minerals at Sites 800,801 , and 802 are dominantly undifferentiated smectites, including rare montmorillonite, that are most likely volcanogenic. The apparent hydrothermal silica that shows up in the turbidite units may in part be due to inadequacies of the partitioning ratios, and to unaccounted-for excess iron that may have been concentrated and mobilized by diagenetic processes. Small amounts of $\mathrm{Fe}$ and $\mathrm{Al}$ in biogenic material (Bostrom, 1976) are also unaccounted for in these partitioning calculations.

\section{Iron}

In the modern Pacific Ocean iron is most concentrated in sediments on the East Pacific rise and in areas of volcanic arcs (Bostrom et al., 1973). The accumulation of Fe in sediments near spreading ridges appears to be proportional to spreading rates, and probably has a magmatic source (Bostrom, 1973; Bishoff et al., 1980; Dean et al., 1989). Iron is carried in slightly reduced $\mathrm{CO}_{2}$-rich fluids, and is the first element to precipitate as amorphous oxides with amorphous silica, as the chemical environment becomes more oxidized at the seafloor, followed by $\mathrm{Mn}, \mathrm{Cu}$, and $\mathrm{Ni}$ (Bostrom et al., 1973; Lonsdale et al., 1980).

At Site $800, \mathrm{Fe}$ is the most abundant in the volcaniclastic unit (Fig. 4), suggesting a predominantly volcanic detrital source. It decreases upward in the overlying unit, possibly indicating a gradationally decreasing volcaniclastic contribution. The tops of Unit III and Unit II are apparently free of volcaniclastic detritus. The slight $\mathrm{Fe}$ enrichment in Unit $\mathrm{V}$ may result in part from hydrothermal or diagenetic mobilization of $\mathrm{Fe}$ from the underlying dolerite sills.

Thin sections from hydrothermal deposits at the base of Site 801 contain coarsely-crystalline quartz and iron oxides that are apparently chemically precipitated. The sediments immediately overlying the basalt contain amorphous iron and silica in addition to abundant radiolarian tests. At Site 801, Fe concentrations (Fig. 4) are generally comparable to those at Site 800 , especially in the turbidite unit, but they are remarkably high in the basal and interpillow sediments. These values are consistent with moderate to fast spreading rates for this mid-ocean ridge (Lancelot, Larson, et al., 1990).

At Site 802, Fe concentrations are low in the chalk unit, and similar to Sites 800 and 801 in the volcaniclastic turbidite units (Fig. 4).

\section{Manganese}

The distribution of $\mathrm{Mn}$ in sediments in the modern Pacific Ocean is mainly associated with spreading ridges and seamounts, suggesting a source similar to that of Fe. However, the diagenetic behavior of $\mathrm{Mn}$ is different from that of $\mathrm{Fe}$. Manganese is very mobile in reducing environments, and requires a more oxidizing environment than $\mathrm{Fe}$ to precipitate. At Sites 800 and $801, \mathrm{Mn}$ may have been preferentially mobilized by diagenetic processes and migrated up the section. Since bottom waters in the central paleo-Pacific apparently were oxidizing, but since organic matter could have reduced buried sediments, Mn may have moved upward through reduced sediments in the sedimentary column, and accumulated at a redox boundary, which commonly occurs where there is a change to slow depositional and accumulation rates (Drever, 1982).

At Site 800, Mn concentrations are highest in Units II and V (Fig. 5), the units with the lowest accumulation rates. Moderate Mn abundances in Unit IV may reflect a volcaniclastic source, or represent pelagic intervals of low accumulation.

At Site 801, Mn is also high in the units with low accumulation rates (Fig. 5). The increase of $\mathrm{Mn}$ in Unit IV relative to underlying Unit V may be due to diagenetic remobilization, since Mn is low relative to $\mathrm{Fe}$ in Unit $\mathrm{V}$, but may be partly hydrothermal.

Manganese is very low in all units at Site 802 (Fig. 5) relative to units at Sites 800 and 801 , but is highest in the pelagic sediments overlying the pillow basalt at the base of the hole.
The $\mathrm{Fe} / \mathrm{Mn}$ ratios of ridge crest hydrothermal sediments is approximately 3 (Bostrom, 1973; Bishoff et al., 1979). Fe/Mn ratios are considerably higher than 3 for all units at all three sites, suggesting, as did the silica calculations, that detrital $\mathrm{Fe}$ is a more significant source of $\mathrm{Fe}$ than hydrothermal Fe, but also that remobilization of $\mathrm{Mn}$ may be an important diagenetic process.

\section{Magnesium}

A major source of magnesium in marine sediments is mafic detritus from weathering of basalt or volcaniclastic material (Bishoff et al., 1979). A detrital source for $\mathrm{Mg}$ at all three sites is indicated by the highest $\mathrm{Mg}$ values in the turbidite units (Fig. 6). $\mathrm{Mg}$ values are also high in the basal units at Site 801 , which could be authigenic $\mathrm{Mg}$ derived from seawater or detrital $\mathrm{Mg}$ derived from weathering of basalt at the seafloor. Carbonate rocks are another source of $\mathrm{Mg}$, but $\mathrm{Mg}$ values are similarly low in the limestone and radiolarite units at all three sites.

\section{Aluminum}

Aluminum in marine sediments is derived dominantly from detrital sources. This is supported by high $\mathrm{Al}$ values in the turbidite units at all three sites (Fig. 7). As with $\mathrm{Mg}$, the high $\mathrm{Al}$ values in the basal sediments at Site 801 strongly suggest weathering of basement as one source for these sediments. This hypothesis is supported by high $\mathrm{Fe} / \mathrm{Mn}$ values for Unit $\mathrm{V}$ at Site 801 .

\section{Phosphorous}

Phosphorous is carried in some hydrothermal fluids (Bostrom, 1973), but is mainly associated with biogenic debris in marine sediments (Berger, 1976). Under more alkaline conditions, phosphate is more mobile than iron, and thus tends to be enriched in more reduced sediments (Price, 1976).

At Sites 800,801 , and 802 the abundance of $\mathrm{P}$ is consistently low, but is highest at the base of the turbidite units (Fig. 8), which are more reduced than the other units. $\mathrm{P}$ is also relatively abundant in the radiolarite/claystone units at Site 801. Fish parts were observed in thin sections of chert, claystone, and volcaniclastic rocks from several units, and thus the likely source of $\mathrm{P}$ at all three sites is fish debris.

\section{Boron}

Boron is considered to be a biogenic indicator and is found mainly in sponge spicules, which are associated with shallow-water deposits (Hein et al., 1981, 1982; Truscott and Shaw, 1983). No shallow-water sediments were drilled on Leg 129, and sponge spicules are extremely rare, only observed in sandstone and chalk turbidites that were redeposited from shallow water.

Boron concentrations are low in all units, and there are no stratigraphic trends (Fig. 9). Special effort was made to measure boron quantitatively. Results indicate that boron is not important in deepwater deposits. In fact, the lack of boron may be useful as a deep-water environmental indicator.

\section{Lanthanum}

Lanthanum abundances in sedimentary rocks reflect total REE abundances because REE have very similar physical and chemical properties (Henderson, 1984). The source of REE in deep marine sediments is controversial, but generally assumed to be seawater, from which it is adsorbed mainly onto authigenic or biogenic phases (Piper, 1974). Eolian or other detritral sources are volumetrically less important.

La abundances in siliceous samples from Leg 129 are generally highest in the samples from pelagic units with the lowest accumulation rates, and higher in the pelagic samples with clay than in pelagic 
ODP SITE 800 (Ce ppm (INAA))

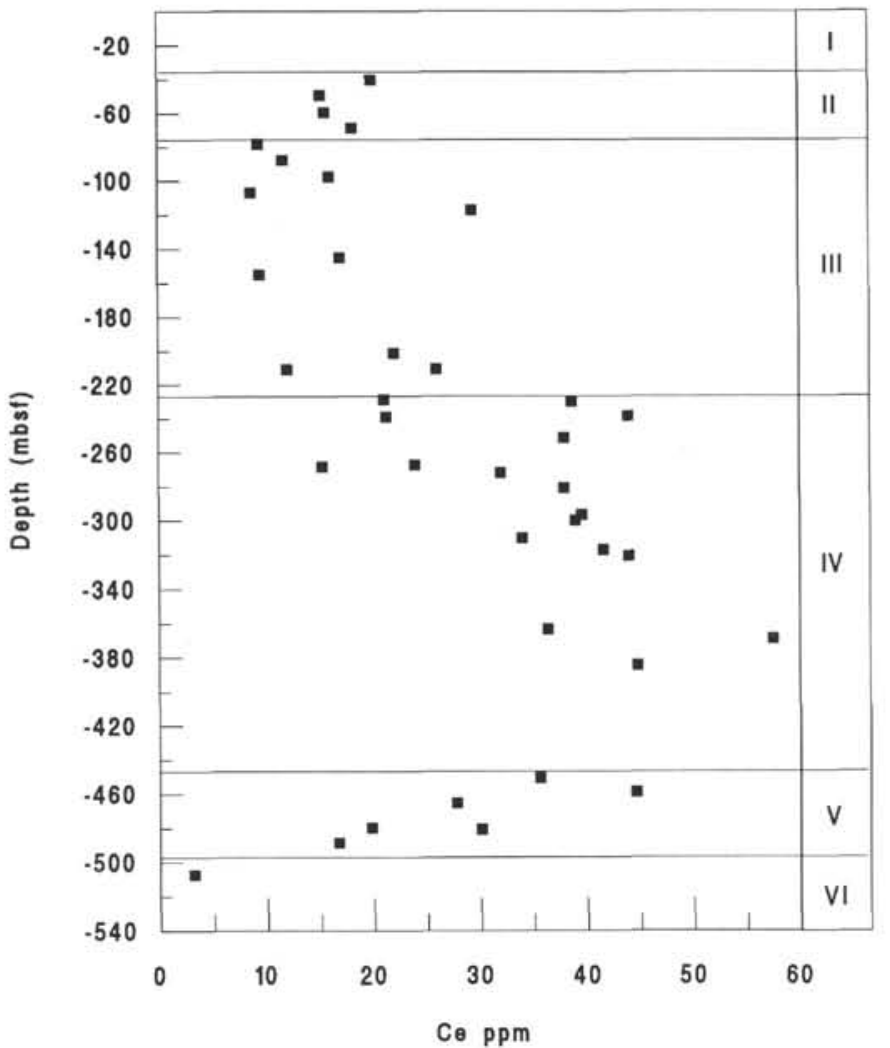

ODP SITE 801 (Ce ppm (INAA))

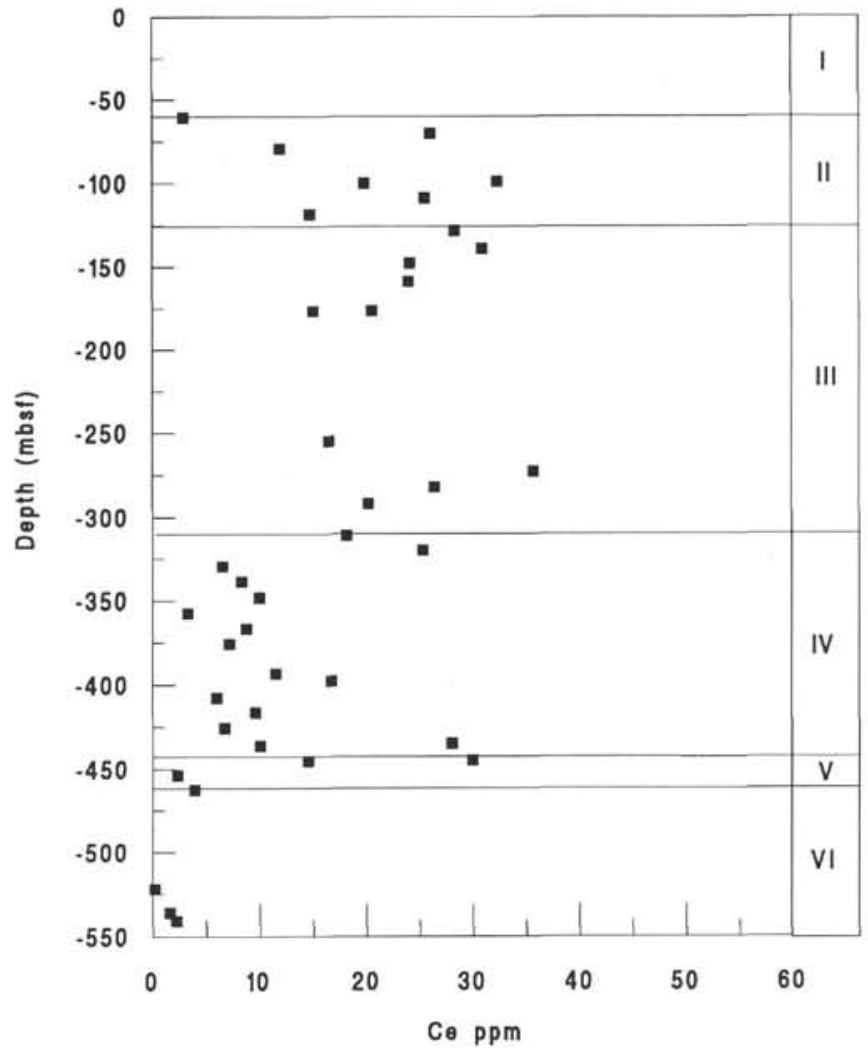

ODP SITE 802 (Ce ppm (INAA))

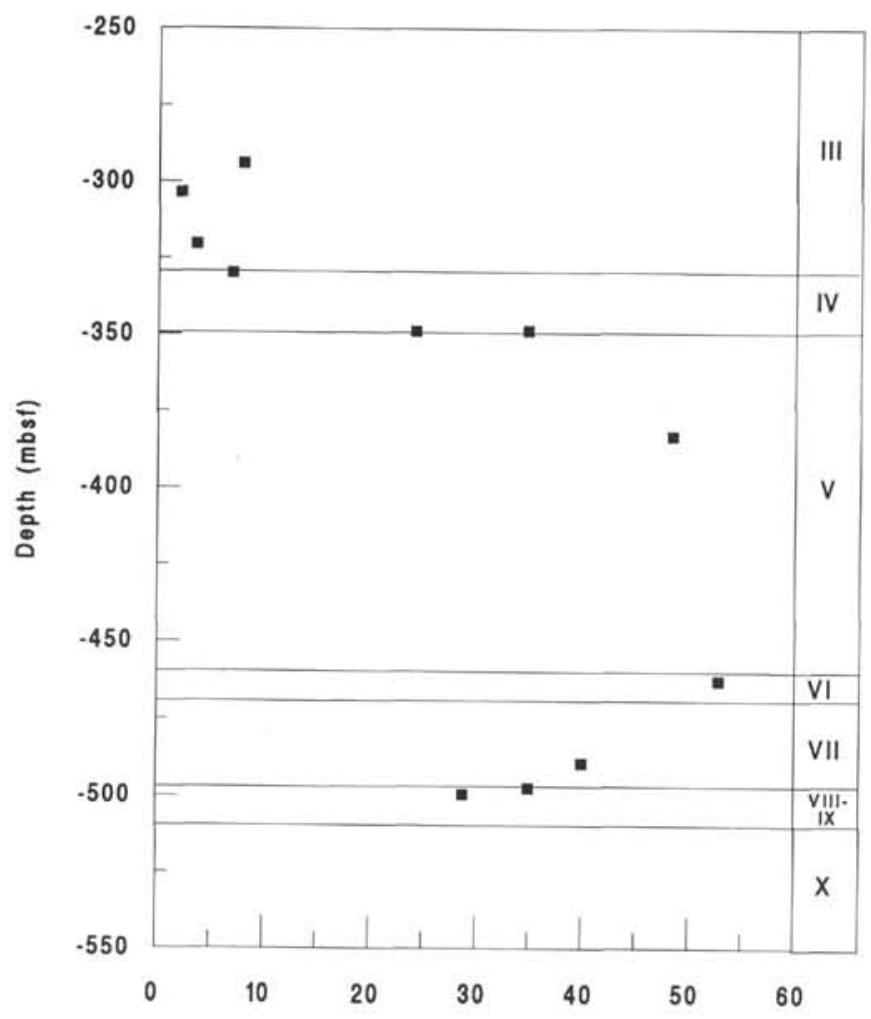

Ce ppm

Figure 11. Cerium contents of samples from Leg 129. 

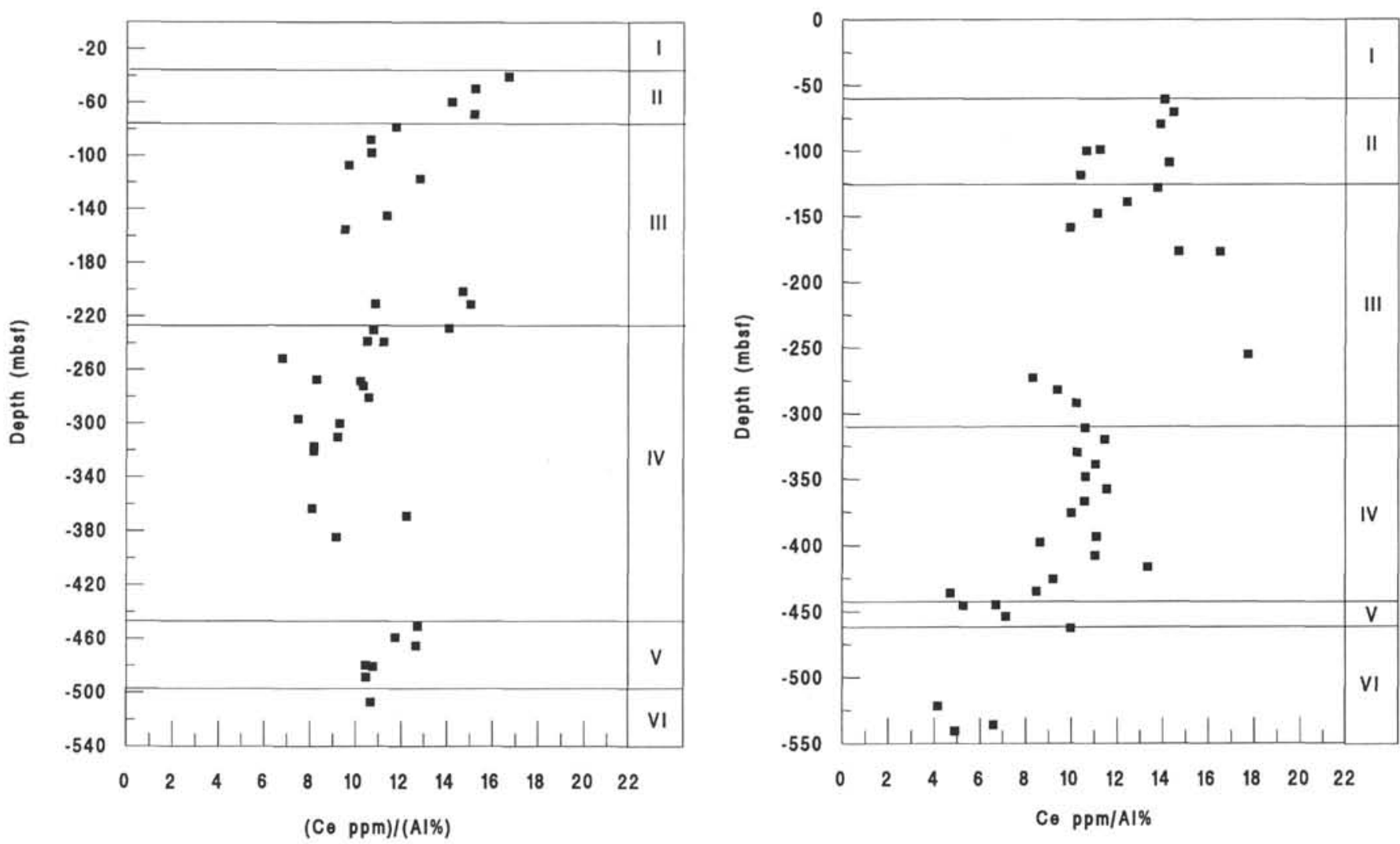

ODP SITE 802 (Ce ppm/Al\%)

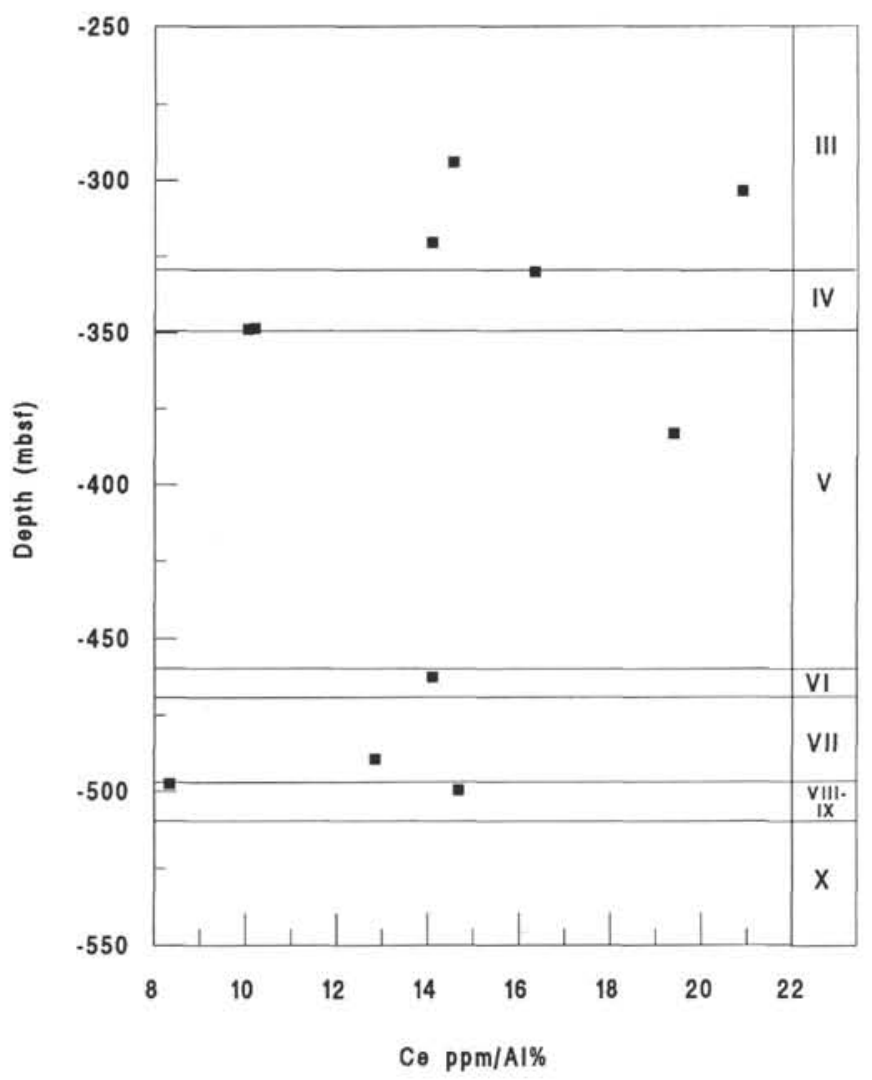

Figure 12. Cerium/aluminum ratios for samples from Leg 129. 
ODP SITE 800 (AI/(Al+Fe+Mn) (XRF AND MICROPROBE))

ODP SITE $801(\mathrm{Al} /(\mathrm{A} \mid+\mathrm{Fe}+\mathrm{Mn})$

(XRF AND MICROPROBE))
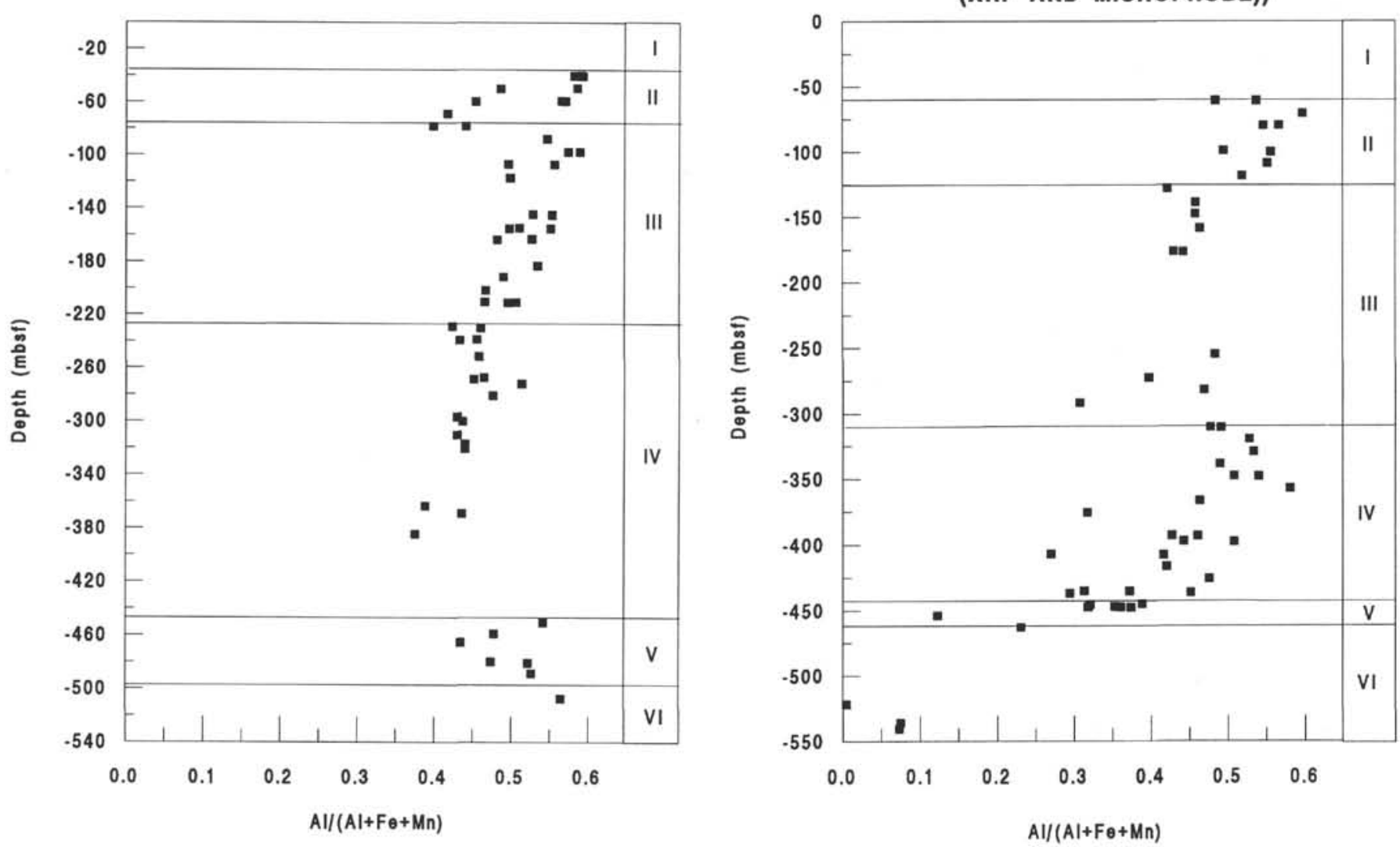

ODP SITE 802 (AI/(AI+Fe+Mn) (XRF))

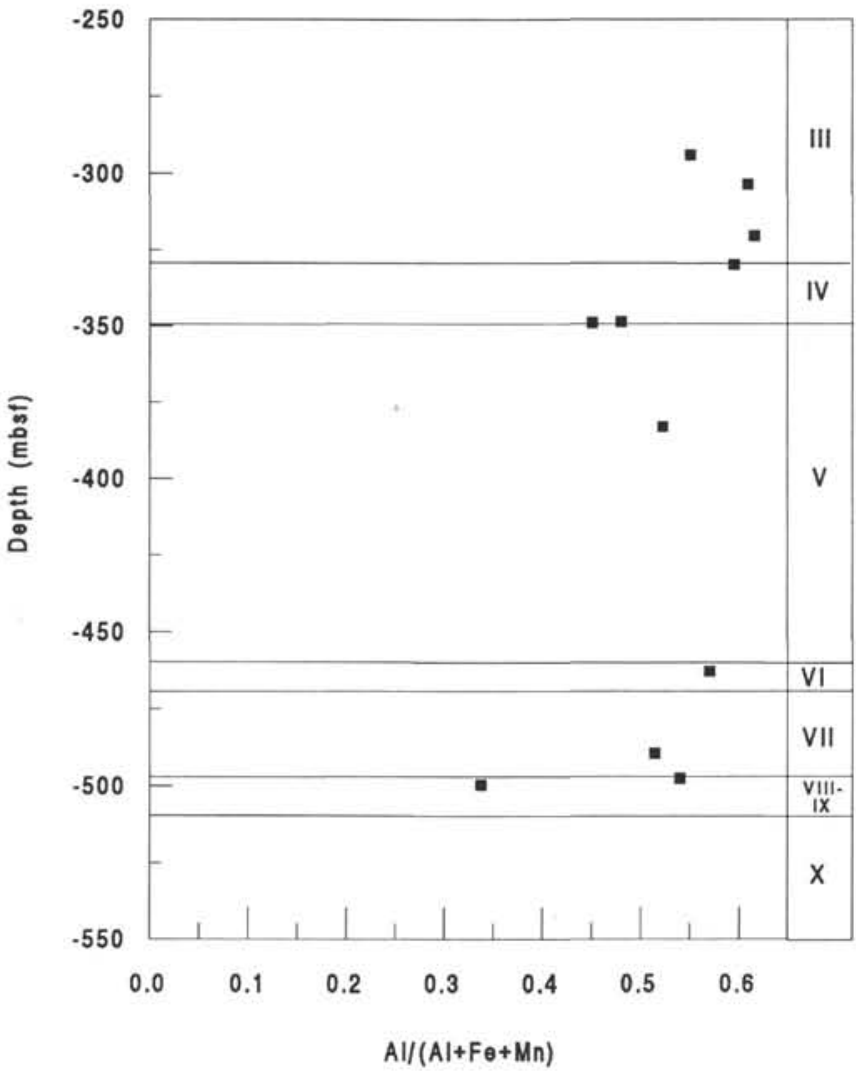

Figure 13. Aluminum/metal ratios for samples from Leg 129. 


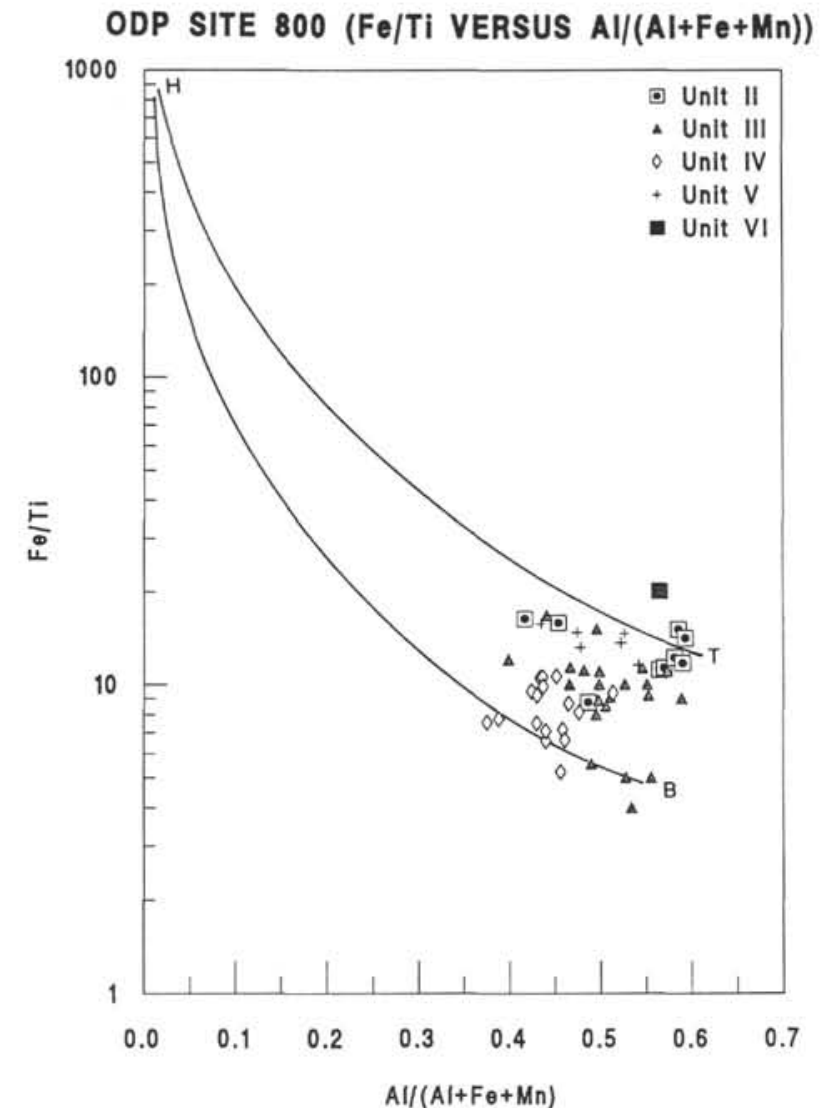

ODP SITE 801 ( $\mathrm{Fe} / \mathrm{Ti}$ VERSUS Al/(Al+Fe+Mn))

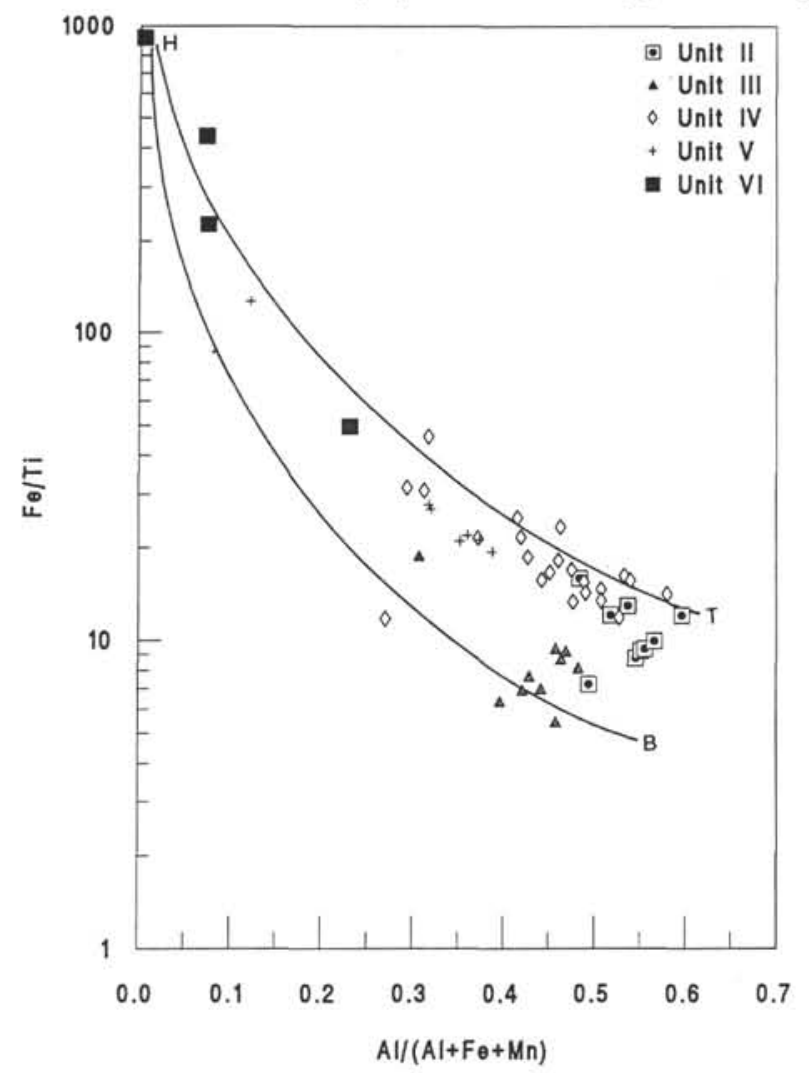

ODP SITE 802 (Fe/Ti VERSUS Al/(Al+Fe+Mn))

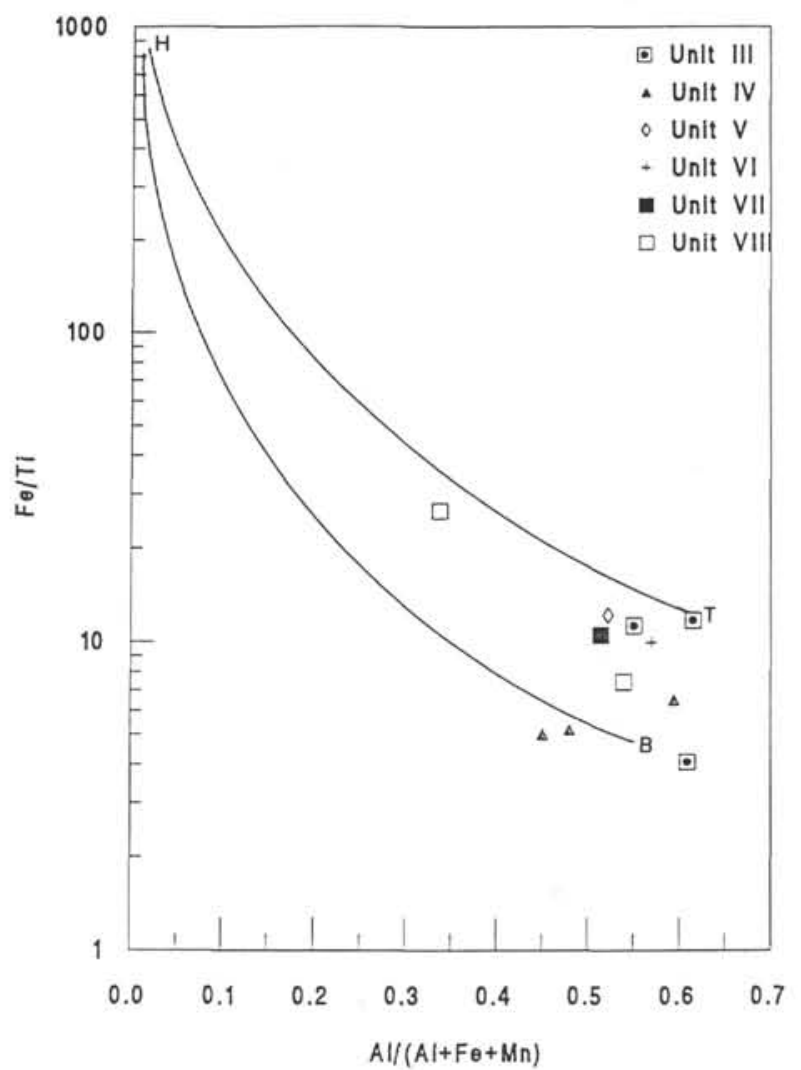

Figure 14. Plot of $\mathrm{Fe} / \mathrm{Ti}$ vs. $\mathrm{Al} /(\mathrm{Al}+\mathrm{Fe}+\mathrm{Mn}$ ) (after Bostrom, 1973). $\mathrm{H}=$ hydrothermal compositional end-member, $\mathrm{T}=$ terrigenous compositional end-member, $\mathrm{B}=$ basaltic compositional end-member. 
samples without clay. There is also a subtle increase in the La contents of samples upsection at each site. At Site 800, the lowest concentrations of La are in radiolarian chert and limestone of Unit III (Fig. 10). The highest concentrations of $\mathrm{La}$ are in claystone samples from the tops of turbidite beds, but high La concentrations are not restricted to these beds. At Site 801, REE are virtually absent in the hydrothermal deposits within the pillow basalt section at the base of the hole (Fig. 10). $\mathrm{La}$ concentrations in the rest of the section are lowest in biogenic samples in Unit VI, deposited on basement, and highest in a clay sample from Unit V near basement. La abundances are higher in the pelagic samples with clay than in the clay-poor radiolarite of Unit IV. At Site 802, La concentrations are lowest in the nannofossil chalk unit and the highest La concentrations of all three sites are in pelagic claystone of Unit VI (Fig. 10).

The relative abundances of $\mathrm{La}$ in the samples studied suggest that high $\mathrm{La}$ (and REE) concentrations correspond to high clay contents, and that clay from units with low accumulation rates have generally higher La abundances than clay associated with the volcaniclastic turbidites. There appears to be a possible detrital source of REE deposited on basement at Site 801, and in the volcaniclastic deposits at all three sites, but an authigenic source for $\mathrm{La}$ and the REE seems to be dominant in all units. A biogenic source for REE is also indicated, but appears to be subordinate to authigenic sources.

\section{Cerium}

Cerium is typically depleted with respect to the other REE in deep-water pelagic sediments. It is not depleted in shallow-water terrigenous sediments (Shimizu and Masuda, 1977; Murray et al., 1990), and it is not depleted in eolian pelagic sediments in the Pacific (Olivarez et al., 1991). Toyoda et al. (1990) found that the negative cerium anomaly is mainly associated with sediments deposited at spreading ridges and equatorial divergence zones, in sediments with low accumulation rates and relatively high REE contents. The depletion of cerium in deep-water sediments is thought to reflect the negative $\mathrm{Ce}$ anomaly that characterizes seawater, which is consequently thought to be the source of REE in deep marine pelagic sediments (Bostrom et al., 1973; Piper, 1974; Henderson, 1984). Cerium is depleted in many pelagic constituents, including foraminifers, pteropods, fish bones, diatoms, and radiolarians, and also in authigenic minerals such as barite, phosphorite, phillipsite, and the various smectites (Piper, 1974; Toyoda et al., 1990). Cerium is not depleted with respect to the other REE in illite or other terrigenous clay minerals, nor is there a cerium anomaly in volcanogenic clay minerals. Cerium is enriched in ferromanganese nodules, which adsorb $\mathrm{Ce}$ from seawater, and may be responsible for the depletion of $\mathrm{Ce}$ in seawater (Piper, 1974). $\mathrm{Ce}$ is preferentially extracted (relative to $\mathrm{La}$ and $\mathrm{Nd}$ ) from seawater because it is the only REE that oxidizes easily in seawater, and oxidized Ce is highly insoluble (Piper, 1974).

Ce concentrations for Leg 129 siliceous deposits (Fig. 11) are generally very similar to La concentrations, with the exception of samples rich in $\mathrm{Mn}$ and $\mathrm{Fe}-\mathrm{Mn}$ oxides. This observation is consistent with high $\mathrm{Ce}$ contents in Fe-Mn oxyhydroxides observed elsewhere in the deep Pacific (Piper, 1974). The distribution of high Ce concentrations supports a dominant authigenic source, ultimately derived from seawater, for $\mathrm{Ce}$. The negative $\mathrm{Ce}$ anomalies for sediments from the pelagic units also supports a seawater source.

\section{CelAl}

Since $\mathrm{La}$ and $\mathrm{Ce}$ abundances suggest a detrital source for some of the REE in units with detrital constituents, the $\mathrm{Ce} / \mathrm{Al}$ ratio was plotted in order to test the proportion of $\mathrm{Ce}$ that is detrital relative to the proportion that is authigenic or biogenic. In general the ratio for all three sites has a similar range. At Site 800 the $\mathrm{Ce} / \mathrm{Al}$ ratio is higher in the pelagic units and lower in the volcaniclastic units, suggesting detrital sources of $\mathrm{Ce}$ are subordinate to pelagic sources (Fig. 12). At Site 801 , the Ce/Al ratio is highest in the brown chert and porcellanite of Unit II, and the lowest of all three sites in basal Units V and VI, distinctly suggesting a detrital source for those sediments, and that $\mathrm{Ce}$ is not derived from this source (Fig. 12). The volcaniclastic deposits also have a relatively low $\mathrm{Ce} / \mathrm{Al}$ ratio. The $\mathrm{Ce} / \mathrm{Al}$ ratios for samples from Site 802 are highest in the dominantly biogenic units, and relatively high for the pelagic interval sampled in the turbidite unit (Fig. 12). The ratio is lowest in the claystone sample from Unit VIII, which may include tuffaceous clay similar to the subjacent unit.

The variation in the $\mathrm{Ce} / \mathrm{Al}$ ratio, and the trend of high values for sediments in pelagic units and low values for sediments in detrital units suggests independent sources for these two elements, and supports an authigenic or seawater source rather than a detrital source for $\mathrm{Ce}$ and the other REE.

\section{MULTIELEMENT PLOTS}

Multielement plots are another method of visually partitioning source components in sedimentary rocks. A few of these plots show interesting trends.

\section{Al-Fe-Mn}

The ratio $\mathrm{Al} /(\mathrm{Al}+\mathrm{Fe}+\mathrm{Mn})$ is an index of detrital clay component, and generally a ratio greater than 0.4 is considered to indicate a detrital source in marine sediments (Bostrom and Peterson, 1969; Bostrom, 1973). All samples studied from Site 800 have values at or above 0.4 for this ratio (Fig. 13). At Site 801, only the lower part of the Unit IV radiolarite, and Units V and VI have values less than 0.4 (Fig. 13), suggesting the lack of a detrital source. At Site 802 , only one sample from Unit VIII has a value less than 0.4 (Fig. 13). Because XRD and microprobe analyses have detected only traces of possible illite in these units (Karpoff, this volume), and because of wind and current patterns in the Pacific Ocean (Kennett, 1982) a terrigenous (eolian) source is likely to be a very small contributor to the high aluminum to metal ratios for these sites. A plot of $\mathrm{Fe} / \mathrm{Ti}$ to $\mathrm{Al} /(\mathrm{Al}+\mathrm{Fe}+\mathrm{Mn})$ (Bostrom, 1973) better clarifies source components for Leg 129 sediments. All of the samples from Site 800 fall in a general area between terrigenous and basaltic compositions (Fig. 14). At Site 801 , however, there is a distinct downsection trend toward the hydrothermal end-member as the position of the samples approaches mid-ocean ridge basalt (MORB) basement, a reflection of the high Fe contents of these sediments (Fig. 14). At Sites 800 and 801 , another discernible trend is that sediments with higher accumulation rates fall closer to the basaltic end-member. The samples from Site 802 tend to plot closer to the basalt end-member (Fig. 14), which also coincides with higher accumulation rates. Samples studied from Unit VIII at Site 802 reflect a slight hydrothermal signature, in support of previous observations of Mn abundance in that unit.

On a triangular plot of Al-Fe-Mn (Fig. 15), with fields defined by clay deposits from specific oceanic environments (Karpoff, 1989), the samples from Sites 801 and 802 fall on a trend from biogenic ooze for the upper units, to oceanic basalts for the lower units in each hole. This is consistent with indications from the single-element plots that volcanic detritus from the seafloor is mixed in with biogenic material near basement. The trend is not so pronounced for Site 800 where the hole bottoms in intrusive rocks rather than basement.

On an Si-Fe-Mn plot (Fig. 16) Leg 129 samples are compared with other types of oceanic clay deposits (Karpoff et al., 1988). The Leg 129 samples fall on a well-defined trend between equatorial mid-ocean ridge sediment and north Pacific red clay, even though many of these samples were deposited south of the equator. Apparently, sediments deposited in the vicinity of the equator and equatorial 
divergence zones have distinctly less Mn than clay deposited in the southern or central Pacific.

\section{Cu-Ba}

Copper and barium in marine sediments are mainly derived from detrital, hydrothermal, and biogenic sources. In biogenic deposits, when detrital and hydrothermal sources can be shown to be negligible, the ratio $\mathrm{Cu} / \mathrm{Ba}$ can be instructive with respect to authigenic, biogenic, and biogenic dissolution residue source components (Karl, 1982). The authigenic contribution should reflect accumulation rates. The boundary between the authigenic and biogenic fields is based on a $\mathrm{Cu} / \mathrm{Ba}$ ratio of 0.15 , and the boundary between the biogenic and dissolution residue fields is defined by a ratio of 0.02 .

At Site 800 , brown chert and porcellanite of Unit II and pelagic clay from between the volcaniclastic turbidite beds of Unit IV fall in the authigenic field (Fig. 17). A low accumulation rate was calculated for Unit II (Table 1), but the authigenic signature of the pelagic clays from Unit IV indicates a slow rate of accumulation for background deposits which is masked by thick turbidite deposits. Samples from the limestone-chert and radiolarite units fall in the biogenic field as well as the authigenic field. Only one sample from the siliceous limestone suggests a high rate of biogenic dissolution, or poor preservation of biogenic ooze.

At Site 801, samples from the radiolarite units fall mainly in the biogenic field; most other samples fall in the authigenic field (Fig. 17), indicating low accumulation rates, as with similar units from Site 800 . Samples from the basal sedimentary unit plot in both fields, supporting possible alternations in depositional rate, as suggested by Ogg et al. (this volume).

At Site 802, all of the samples except one from the calcareous unit fall in the authigenic field (Fig. 17).

\section{RARE EARTH ELEMENT PATTERNS}

REE patterns provide another means of testing for source components of marine sediments. Characteristic REE abundances and patterns have been determined for terrigenous clay deposits (Fig. 18) and for pelagic clay deposits, umbers (spreading ridge sediments), ferromanganese nodules, and seawater (Fig. 19). REE patterns and abundances for various types of basalt cored at Sites 800,801 , and 802 are available for comparison in Floyd and Castillo (this volume).

Comparison of REE patterns of Leg 129 samples studied (Fig. 20) with those of terrigenous shale and pelagic clay (Figs. 18 and 19) shows a distinct difference, based on both REE abundances and on the presence or absence of a $\mathrm{Ce}$ anomaly. Patterns and abundances indicate the source of REE in Leg 129 samples is seawater. The high biogenic source component in Leg 129 samples supports this conclusion because REE are adsorbed from seawater onto planktonic tests (Bostrom et al., 1973; Piper, 1974). REE may also be incorporated in primary and authigenic minerals from pore waters during early and late diagenesis (German and Elderfield, 1990), and La and Ce abundances for Leg 129 samples suggest this is a more important process than biogenic adsorption. Alternatively, REE adsorbed onto biogenic tests could subsequently be incorporated into authigenic minerals during diagenetic processes. REE patterns, especially the Ce anomaly, also reflect redox conditions of deposition and diagenesis.

Marine clay deposits are commonly normalized to "average shale" using one of the sources in Figure 18, but for several reasons, "average shale" is considered inappropriate for Leg 129 samples: (1) the lack of eolian quartz grains, the scarcity of illite, and chemical element abundances and ratios argue against a terrigenous source, (2) a negative cerium anomaly suggests a dominant seawater source for REE for most Leg 129 samples studied, and (3) REE patterns for some units suggest the source is mixed. Normalization to seawater would not allow ready comparison to other sediments or sources since this approach has not been taken by other workers. Normalization to chondrite is a com- monly used standard of comparison, and has the additional advantage of comparability to basalt REE patterns from Leg 129 , since volcanic material derived from basement or local volcanic activity has been targeted as an important sedimentary source.

REE patterns for the different units from Leg 129 are generally light rare earth element (LREE) enriched with negative cerium and europium anomalies. Seawater is not LREE enriched (Fig. 19). The basalt samples from Leg 129 include several units with different chemical characteristics. Site 801 basement has an upper sequence of LREE-enriched alkali basalt and a lower sequence of LREE-depleted tholeiitic basalt (Floyd and Castillo, this volume). Site 802 basalt is homogenous, undepleted tholeiite (Floyd et al., this volume). The basalt has no cerium anomaly, and only the lower tholeiite at Hole $801 \mathrm{C}$ has a small negative europium anomaly. The only basalt that has an REE pattern similar to the sedimentary rocks studied is the LREE-enriched upper alkali basalt at Site 801 . Volcanic sources of the turbidites may or may not have been LREE enriched. Terrigenous shales are LREE enriched (Fig. 18), but factors previously discussed argue against this source. LREE enrichment can be a result of diagenetic low-oxygen conditions in biogenic sediments (German and Elderfield, 1990), but evidence cited above indicates these red sedimentary rocks were deposited under oxidizing conditions and only show subtle signs of reduction in some places.

At Site 800, chert and siliceous limestone of Units II and III are LREE enriched with pronounced negative $\mathrm{Ce}$ and $\mathrm{Eu}$ anomalies (Fig. 20A, B). The Ce anomaly is probably due to adsorption of REE from seawater by plankton and authigenic minerals. A negative Eu anomaly in deep-water marine sediments may be derived from seawater (Fig. 19). Negative Eu anomalies are also found in eolian material or hydrothermal precipitates (Elderfield, 1988), neither of which is common in these Leg 129 deposits. However the negative Eu anomalies in most Leg 129 siliceous deposits may reflect an authigenic source derived from some combination of these three potential sources. Steinberg et al. (1983) suggested that positive Eu anomalies in marine sediments probably reflect feldspar content. The lack of a $\mathrm{Ce}$ anomaly for almost all of the samples from the volcaniclastic unit (Fig. 20C), and the Ce/Al ratio for this unit (Fig. 12), also suggest mixed sources. Samples from the radiolarite of Unit V for REE (Fig. 20D) have a slight negative $\mathrm{Ce}$ anomaly, much smaller than the $\mathrm{Ce}$ anomalies of biogenic Units II and III. This may reflect some volcaniclastic input for Unit V. The lowest sample from Site 800 , from between the dolerite sills, has very low REE contents, and negative $\mathrm{Ce}$ and Eu anomalies (Fig. 20E). This sample is recrystallized chert, and its protolith may have been similar to the radiolarite of Unit V. The low REE contents may reflect a more dominant biogenic source for this sample than for the radiolarite of Unit V.

At Site 801 the brown chert of Unit II has an identical REE pattern to the chert of Unit II at Site 800 (Fig. 20A, F). The pelagic clay from Unit III turbidites (Fig. 20G) has a very similar pattern to the turbidites at Site 800 (Fig. 20C), virtually lacking a Ce anomaly. Unit IV radiolarite at Site 801 has low REE contents, and most samples have a negative $\mathrm{Ce}$ anomaly (Fig. 20H). This unit has common Fe-Mn micronodules, which may have imparted additional $\mathrm{Ce}$ to the samples with no negative Ce anomaly, as described by Piper (1974). The pronounced negative Eu anomaly may reflect seawater or authigenic sources. The radiolarite and claystone of Unit V at Site 801 have similar REE patterns and abundances (Fig. 20) to pelagic Units II of Sites 800 (Fig. 20A) and 801 (Fig. 20F), which may have accumulated under similar conditions near the equator. The interpillow chert at the base of the Site 801 section has very low REE abundances (Fig. 20J), with a pattern similar to seawater (Fig. 19). The hydrothermal quartz has even lower REE contents, also with a pattern that resembles seawater (Fig. 20J).

Chert and limestone of Unit III at Site 802 have a strong negative $\mathrm{Ce}$ anomaly, a small negative Eu anomaly, and relatively low REE contents (Fig. 20K). Unit IV brown claystone (Fig. 20L) is similar to the brown chert of Units II at Sites 800 and 801 . Unit V pelagic 
claystone from between turbidite beds (Fig. 20M) has a similar signature (with very small negative $\mathrm{Ce}$ anomaly and small negative $\mathrm{Eu}$ anomaly) to the pelagic claystone from the correlative Cretaceous turbidite units at Sites 800 and 801 . Radiolarian claystone of Units VI, VII, and VIII have similar light REE-enriched patterns with subtle $\mathrm{Ce}$ and Eu anomalies (Fig. 20N, O, P) that may reflect dilution by volcaniclastic material.

\section{SUMMARY AND CONCLUSIONS}

The siliceous rocks studied from Leg 129 have complicated geochemical signatures reflecting multiple sedimentary sources. Abundant radiolarians, high silica concentrations, and major and minor element partitioning equations and plots indicate a dominant biogenic source for most of the samples studied. XRD and microprobe analyses of mineral contents, $\mathrm{Fe}$ and $\mathrm{Al}$ concentrations, and element partitioning equations identified a significant volcaniclastic source for samples from pelagic intervals in turbidite units, and for samples from units directly overlying volcanic rocks. Abundant siliceous microfossils and high $\mathrm{Si}$ and $\mathrm{Ba}$ signify high biogenic productivity as background sedimentation during volcaniclastic turbidite deposition. High $\mathrm{Fe}$ concentrations in interpillow sediments and sediments overlying spreading ridge basement at Site 801 signify hydrothermal input, which is only evident for these basal sediments. Mn distributions indicate mobilization by diagenetic processes. $\mathrm{Cu} / \mathrm{Ba}$ ratios indicate element concentrations were also influenced by authigenic processes in lithol-ogies with low accumulation rates. The very low abundance of B in these deep marine deposits reinforces its usefulness as a shallow-water indicator. The relative abundance and distribution of REE, as well as REE patterns for samples studies, suggest seawater, through authigenic or biogenic processes, is the primary source of REE in deep marine sediments, but a subordinate detrital source is indicated for some units. Volcanic episodes contributed detrital material to the sedimentary sequences at Leg 129 sites at slightly different times during the Mesozoic and Tertiary, and reworking of bottom sediments and redistribution of clay minerals beyond the most distal turbidite deposits by bottom currents may also have been an important process.

Paleomagnetic evidence (Steiner and Wallick, this volume; Ogg et al., this volume) indicates that all three sites were near the equator for most of the time the samples studied represent. Accumulation rates and sediment compositions for Leg 129 deposits suggest that sedimentation was not symmetrical about the equator, nor consistent within respective equatorial depositional zones through time. Accumulation rates in the late Mesozoic were much higher in the southern part of the equatorial divergence zone than in the northern part. The southern part of the equatorial zone was also apparently broader than the part north of the equator. During the Jurassic, only siliceous deposits accumulated in the equatorial zone, but during the Cretaceous siliceous limestone accumulated. During the Tertiary accumulation rates were lower and considerably less biogenic material is preserved. Paleoceanographic models (Berger, 1976; Kennett, 1982) suggest that the equatorial province was a zone of high productivity during this time, and that these sites were isolated from terrigenous influence. Leg 129 stratigraphic data supports these models. The geochemistry of Leg 129 siliceous rocks also supports these models, and provides additional information regarding the oxic depositional conditions and variations in biogenic, authigenic, and volcanogenic input near the equator during the late Mesozoic.

\section{ACKNOWLEDGMENTS}

We would like to express our gratitude to Floyd Brown of the U.S. Geological Survey for expediting chemical analyses; to analytical chemists Zoe Ann Brown, Elizabeth Bailey, Dave Siems, Joe Taggert, and Paul Lamothe; to Jonathan Whitesides for sample preparation; and to Scott Bie for organizing and plotting data. We would like to thank reviewers David Z. Piper, James R. Hein, and Peter Hempel. We also thank our fellow Leg 129 scientists, the drilling crew, and the ship crew on the JOIDES Resolution for their help.

\section{REFERENCES}

Anders, E., and Ebihara, M., 1982. Solar system abundances of the elements. Geochim. Cosmochim. Acta, 46:2363-2380.

Arthur, M. A., Dean, W. E., Bottger, D., and Scholle, P. A., 1984. Rhythmic bedding in Mesozoic-Cenozoic pelagic carbonate sequences: the primary and diagenetic origin of Milankovich-like cycles. In Berger, A., Imbrie, J., Hays, J., Kukla, G., and Saltzman, B. (Eds.), Milankovitch and Climate (Pt. 1): Dordrecht (D. Reidel), 191-222.

Bender, M., Broecker, W., Garnitz, V., Middel, U., Kay, R., Sun, S.-S., and Biscaye, P., 1971. Geochemistry of three cores from the East Pacific Rise. Earth Planet. Sci. Lett., 12:425-433.

Berger, W. H., 1976. Biogenous deep sea sediments: production, preservation and interpretation. In Riley, J. P., and Chester, R. (Eds.), Chemical Oceanography (Vol. 5): San Francisco (Academic Press), 265-388.

Bishoff, J. L., Heath, G. R., and Leinen, M., 1979. Geochemistry of deep sea sediments from the Pacific Manganese nodule province: Domes Sites A, B, C. In Bishoff, J. L., and Piper, D. Z. (Eds.), Marine Geology and Oceanography of the Pacific Manganese Nodule Province: New York (Plenum), 397-436.

Bishoff, J. L., Piper, D. Z., and Quinterno, P., 1980. Nature and origin of metalliferous sediments in DOMES Site C, Pacific manganese nodule province. In La Genese des Nodules Manganese. Coll. Int. C.N.R.S., 289:119-137.

Bonatti, E., Zerbi, M., Kay, R., and Rydell, H., 1976. Metalliferous deposits from the Appenine ophiolites: Mesozoic equivalents of deposits from modern spreading centers. Geol. Soc. Am. Bull., 87:83-94.

Bostrom, K., 1973. The origin and fate of ferromanganoan active ridge sediments. Stockholm Contrib. Geol., 27:149-243.

1976. Particulate and dissolved matter as sources for pelagic sediments. Stockholm Contrib. Geol., 30:15-79.

Bostrom, K., Joensuu, O., and Brohm, I., 1974. Plankton: its significance as a source of pelagic sediment. Chem. Geol., 14:255-271.

Bostrom, K., Kraemer, T., and Gartner, S., 1973. Provenance and accumulation rates of opaline silica, $\mathrm{Al}, \mathrm{T}, \mathrm{Fe}, \mathrm{Mn}, \mathrm{Cu}, \mathrm{Ni}$, and $\mathrm{Co}$ in Pacific pelagic sediments. Chem. Geol., 11:123-148.

Bostrom, K., and Peterson, M.N.A., 1969. Origin of aluminum poor ferromanganoan sediments in areas of high heat flow on the East Pacific Rise. Mar. Geol., 7:427-447.

Drever, J. I., 1982. Geochemistry of Natural Waters: Englewood Cliffs, NJ (Prentice Hall).

Elderfield, H., 1988. The oceanic chemistry of the rare earth elements. Philos. Trans, R. Soc. London A, 325:105-126.

German, C. R., and Elderfield, H., 1990. Application of the Ce anomaly as a paleoredox indicator: the ground rules. Paleoceanography, 5:823-833.

Gromet, L. P., Dymek, R. F., Haskin, L. A., and Korotev, R. L., 1984. The North American shale composite: its compilation, major and trace element characteristics. Geochim. Cosmochim. Acta, 48:2469-2482.

Heath, G.R., 1974. Dissolved silica in deep sea sediments. In Hay, W.W. (Ed.), Studies in Paleo-oceanography. Spec. Publ.-Soc. Econ. Paleontol. Mineral., 20:77-93.

Heath, G. R., and Dymond, J., 1977. Genesis and transformation of metalliferous sediment from the East Pacific Rise, Bauer Deep, and Central Basin, northwest Nazca plate. Geol. Soc. Am. Bull., 88:723-733.

Heath, G. R., and Moberly, R., 1971. Cherts from the western Pacific, Leg 7, Deep Sea Drilling Project. In Winterer, E. L., Riedel, W. R., et al., Init. Repts. DSDP, 7: Washington (U.S. Govt. Printing Office), 991-1007.

Heath, G. R., Moore, T. C., and Roberts, G. S., 1974. Mineralogy of surface sediments from the Panama Basin, eastern equatorial Pacific. J. Geol., 82:145-160.

Hein, J. R., Sancetta, C., and Morgenson, L. A., 1982. Petrology and geochemistry of silicified upper Miocene chalk, Costa Rica rift, Deep Sea Drilling Project Leg 69. In Cann, J. R., Langseth, M. G., et al., Init. Repts. DSDP, 69: Washington (U.S. Govt. Printing Office), 69:395-422.

Hein, J. R., Vallier, T. L., and Allan, M. A., 1981. Chert petrology and geochemistry mid-Pacific Mountains and Hess Rise, Deep Sea Drilling Project Leg 62. In Thiede, J., Vallier, T. L., et al., Init. Repts. DSDP, 62: Washington (U.S. Govt. Printing Office), 711-748.

Henderson, P. (Ed.), 1984. Rare Earth Element Geochemistry: New York (Elsevier), Dev. in Geochem. Ser., 1-32. 
Jenkyns, H. C., 1978. Pelagic environments. In Reading, H.G. (Ed.), Sedimentary Environments and Facies: Oxford (Blackwell Sci. Publ.), 314-371.

Karl, S. M., 1982. Geochemical and depositional environments of Upper Mesozoic radiolarian cherts from the northwestern Pacific rim and from Pacific DSDP cores [Ph.D dissert.]. Stanford Univ., Stanford, CA.

Karpoff, A. M., 1989. Les facies pelagiques condenses Cenozoiques des oceans Pacifique and Atlantique: temoins des grandes crises geodynamiques [These Doc. Sci.]. Univ. Louis Pasteur, Strasbourg, France.

Karpoff, A. M., Walter, A. V., and Pflumio, C., 1988. Metalliferous sediments within lava sequences of the Sumail ophiolite (Oman): mineralogical and geochemical characterization, origin, and evolution, Tectonophysics, 151:223-245.

Keene, J. B., 1976. The distribution, mineralogy and petrography of biogenic and authigenic silica from the Pacific basin [Ph.D. dissert.]. Univ. of California, San Diego.

Kelts, K., and Arthur, M. A., 1981. Turbidites after ten years of deep-sea drilling-wringing out the mop? Spec. Publ.-Soc. Econ. Paleontol. Mineral., 32:91-127.

Kennett, J. P., 1982. Marine Geology: Englewood Cliffs, NJ (Prentice Hall).

Lancelot, Y., Larson, R. L., et al., 1990. Proc. ODP, Init. Repts., 129: College Station, TX: Ocean Drilling Program.

Larson, R. L., and Pittman, W. C., III, 1973. Worldwide correlation of Mesozoic magnetic anomalies and its implications. Geol. Soc. Am. Bull., 83:3645-3662.

Leinen, M., 1981. Metal-rich basal sediments from northeastern Pacific Deep Sea Drilling sites. In Yeats, R. S., Haq, B. U., et al., Init. Repts. DSDP, 63: Washington (U.S. Govt. Printing Office), 63:667-676.

Leinen, M., and Pisias, N., 1982. An objective technique for determining end-member compositions and for partitioning sediments according to their sources. Geochim. Cosmochim. Acta, 48:47-62.

Leinen, M., and Stakes, D., 1979. Metal accumulation rates in the central equatorial Pacific during the Cenozoic. Geol. Soc. Am. Bull., 90:357-375.

Lonsdale, P. F., Bishoff, J. L., Burns, V. M., Kastner, M., and Sweeney, R. E. 1980. A high-temperature hydrothermal deposit on the seabed at a Gulf of California spreading center. Earth Planet. Sci. Lett., 49:8-20.

Murray, R. W., Buchholtz ten Brink, M. R., Jones, D. L., Gerlach, D. C., and Russ, GP., III, 1990. Rare earth elements as indicators of different marine depositional environments in chert and shale. Geology, 18:268-271.
Olivarez, A. M., Owen, R. M., and Rea, D. K., 1991. Geochemistry of eolian dust in Pacific pelagic sediments: implications for paleoclimactic interpretations. Geochim. Cosmochim. Acta, 55:2147-2158.

Piper, D. Z., 1974. Rare earth elements in the sedimentary cycle: a summary. Chem. Geol., 14:285-304.

Price, N. B., 1976. Chemical diagenesis in sediments. In Riley, J. P., and Chester, R. (Eds.), Chemical Oceanography, San Francisco (Academic Press), 6:1-59.

Rea, D. K., Pisias, N. G., and Newberry, T., 1991. Late Pleistocene paleoclimatology of the central equatorial Pacific: flux patterns of biogenic sediments. Paleoceanography, 6:227-244.

Research on Cretaceous Cycles Group (RCCG), 1986. Rhythmic bedding in Upper Cretaceous pelagic carbonate sequences: varying sedimentary response to climatẹ forcing. Geology, 14:153-156.

Robertson, A.H.F., and Fleet, A. J., 1976. The origins of rare earths in metalliferous sediments of the Troodos Masif, Cyprus. Earth Planet. Sci. Lett., 28:385-394.

Rona, P. A., Bostrom, K., and Epstein, S., 1980. Hydrothermal quartz vug from the mid-Atlantic Ridge. Geology, 8:569-572.

Shimizu, H., and Masuda, A., 1977. Cerium in chert as an indication of marine environment of its formation. Nature, 266: 346-348.

Steinberg, M., Bonnot-Courtois, C., and Tlig, S., 1983. Geochemical contribution to the understanding of bedded chert. In Iijima, A., Hein, J. R., and Siever, R. (Eds.), Siliceous Deposits in the Pacific Region: Amsterdam (Elsevier), Dev. in Sedimentol. Ser., 36:193-210.

Toyoda, K., Nakamura, Y., and Masuda, A., 1990. Rare earth elements of Pacific pelagic sediments. Geochim. Cosmochim. Acta, 54:1093-1103.

Truscott, M. G., and Shaw, D. M., 1983. Boron in cherts. Progr. Abstracts, Geol. Assoc. Can., A70.

Date of initial receipt: 19 June 1991

Date of acceptance: 24 March 1992

Ms 129B-111 
[BLANK PAGE] 

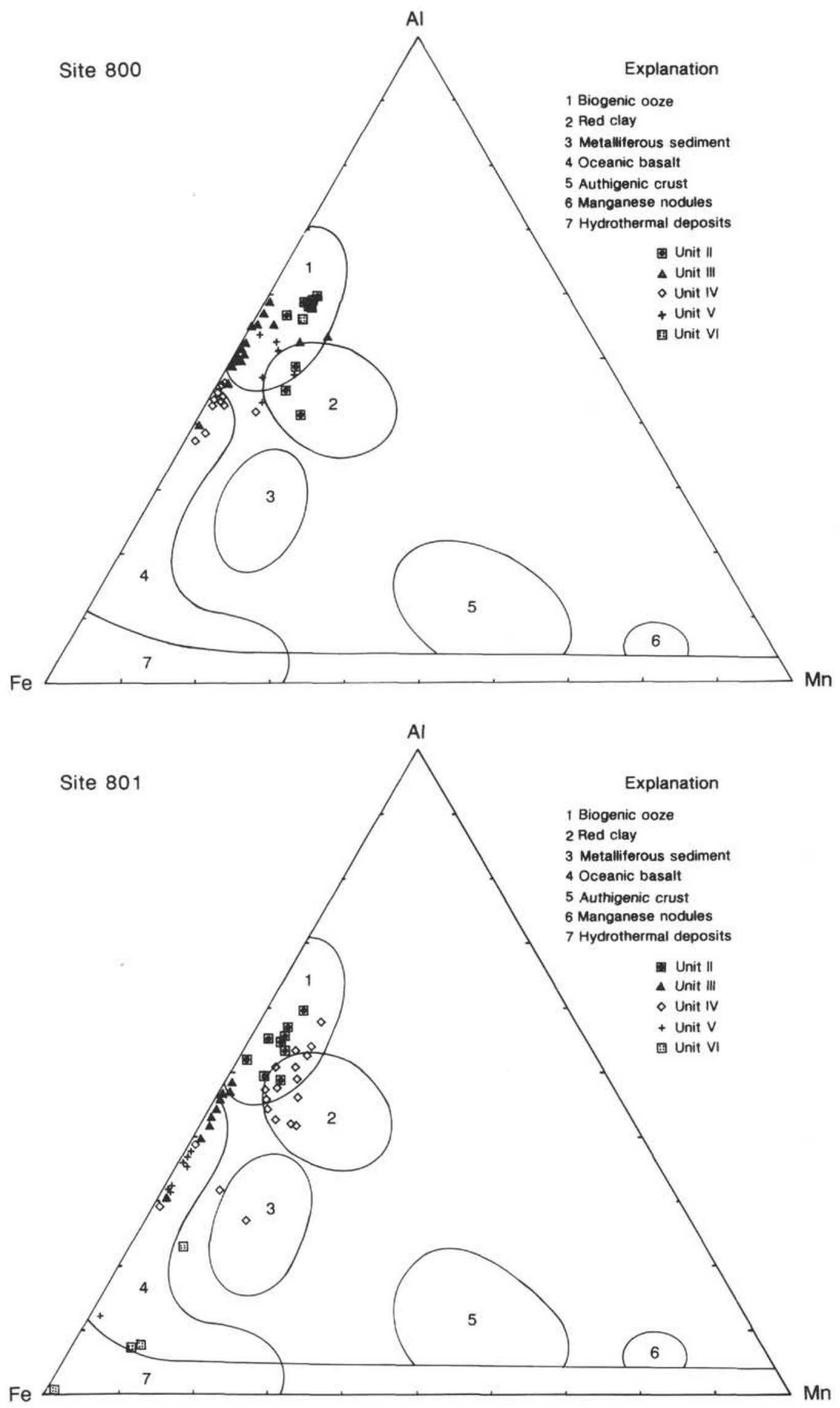

Figure 15. Plot of Al-Fe-Mn for samples from Leg 129. Fields from Karpoff (1989). 


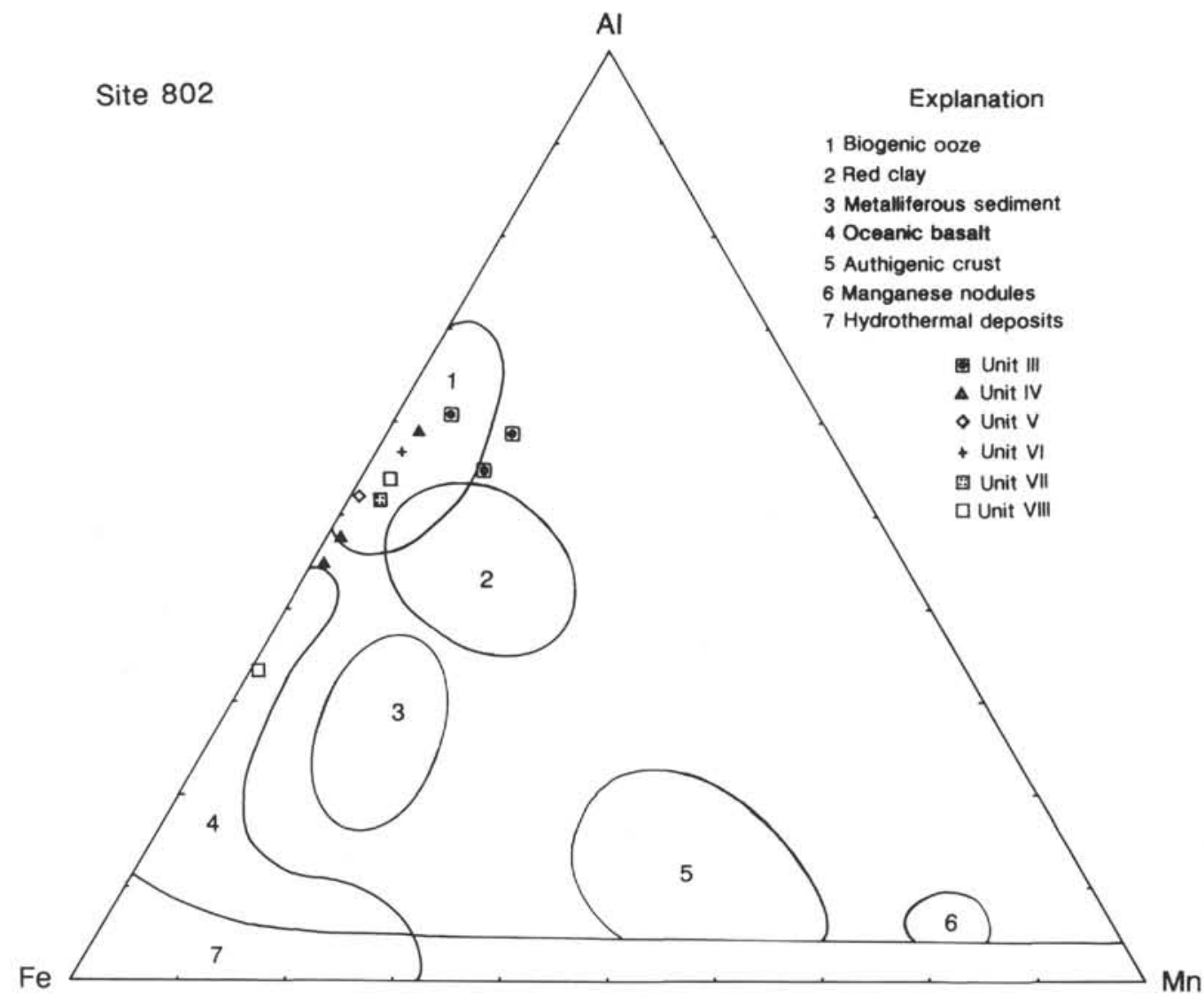

Figure 15 (continued). 

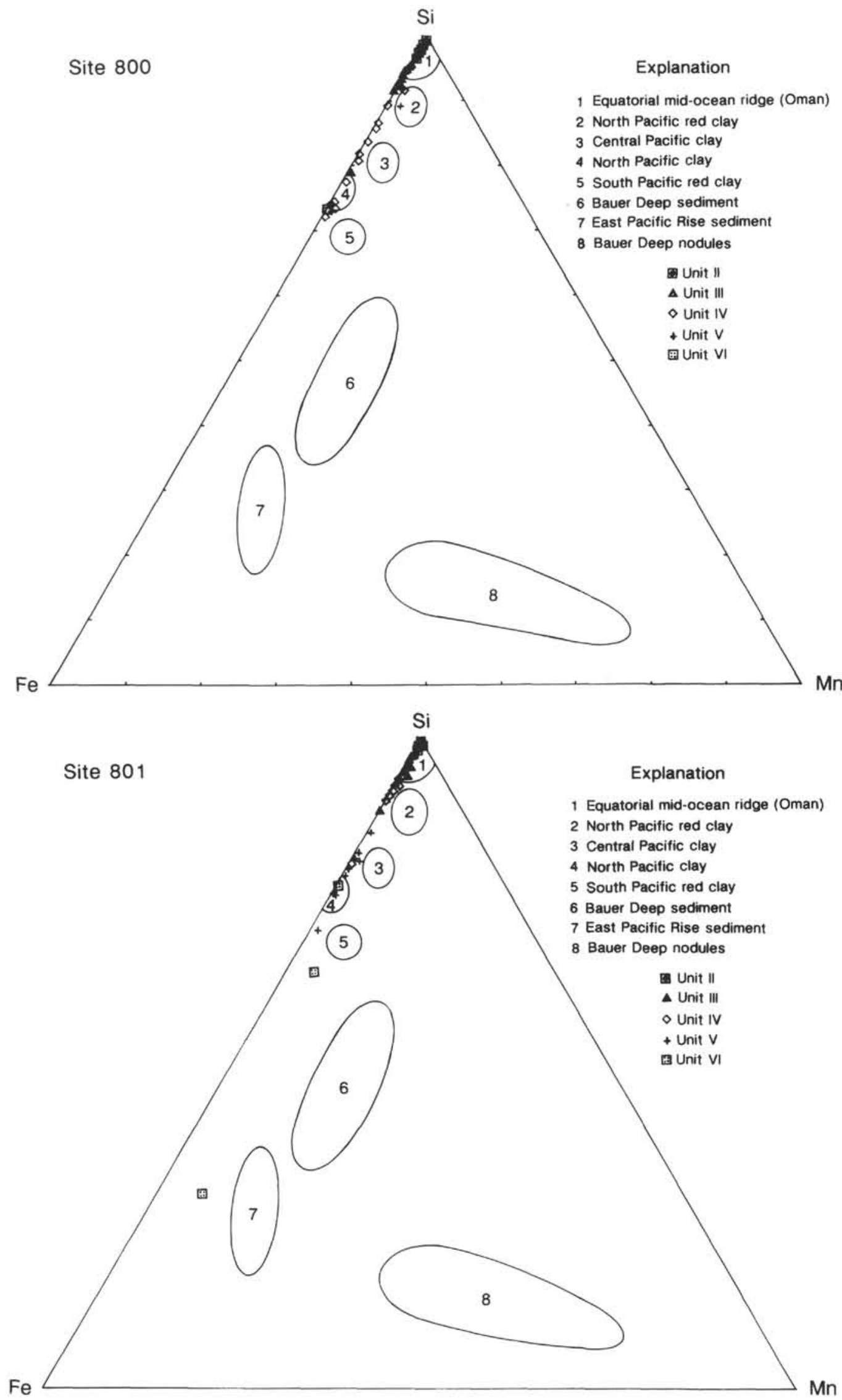

Figure 16. Plot of Si-Fe-Mn for samples from Leg 129. Fields from Karpoff et al. (1988). 


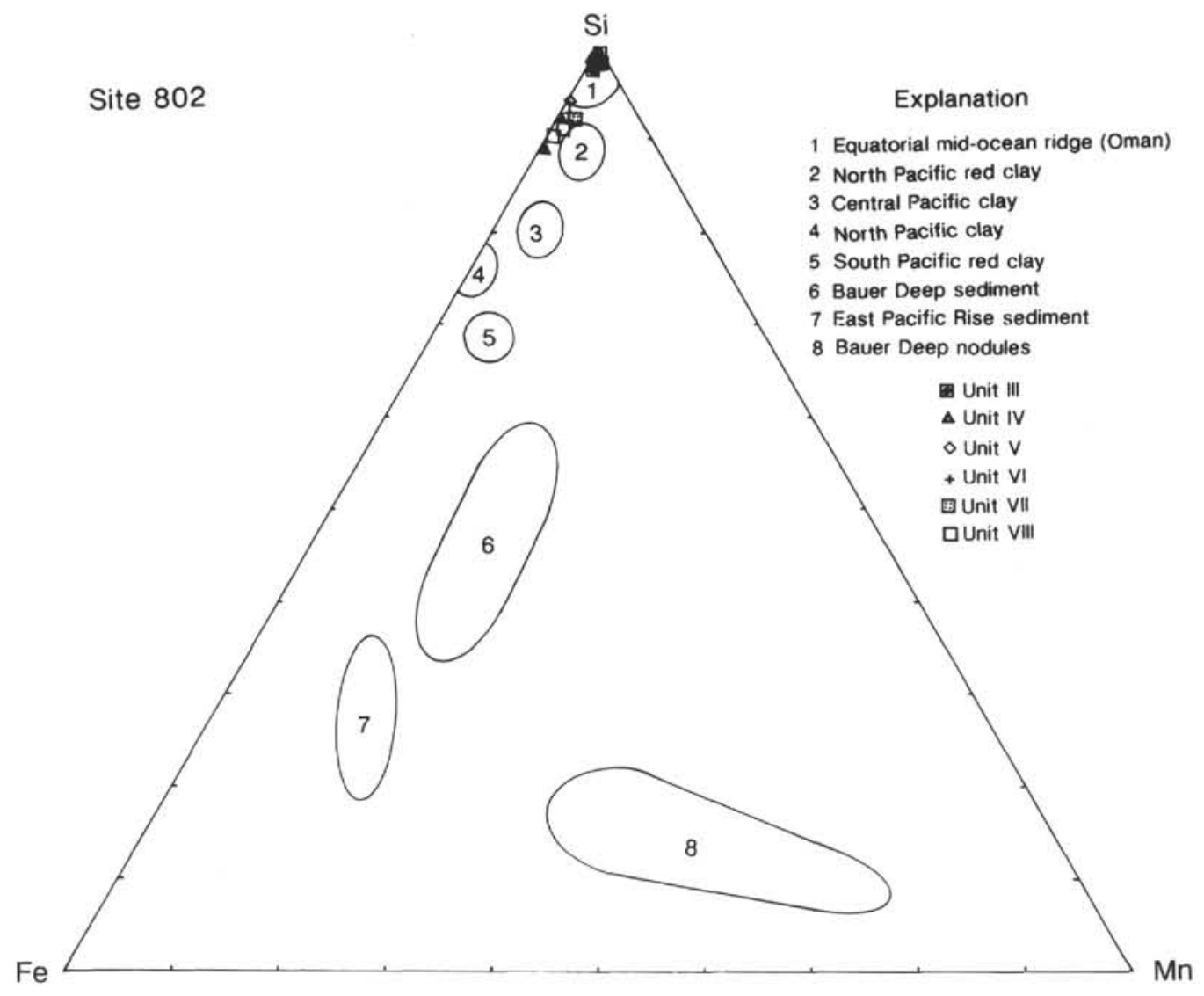

Figure 16 (continued). 
ODP SITE 800 (Cu ppm VERSUS Ba ppm)

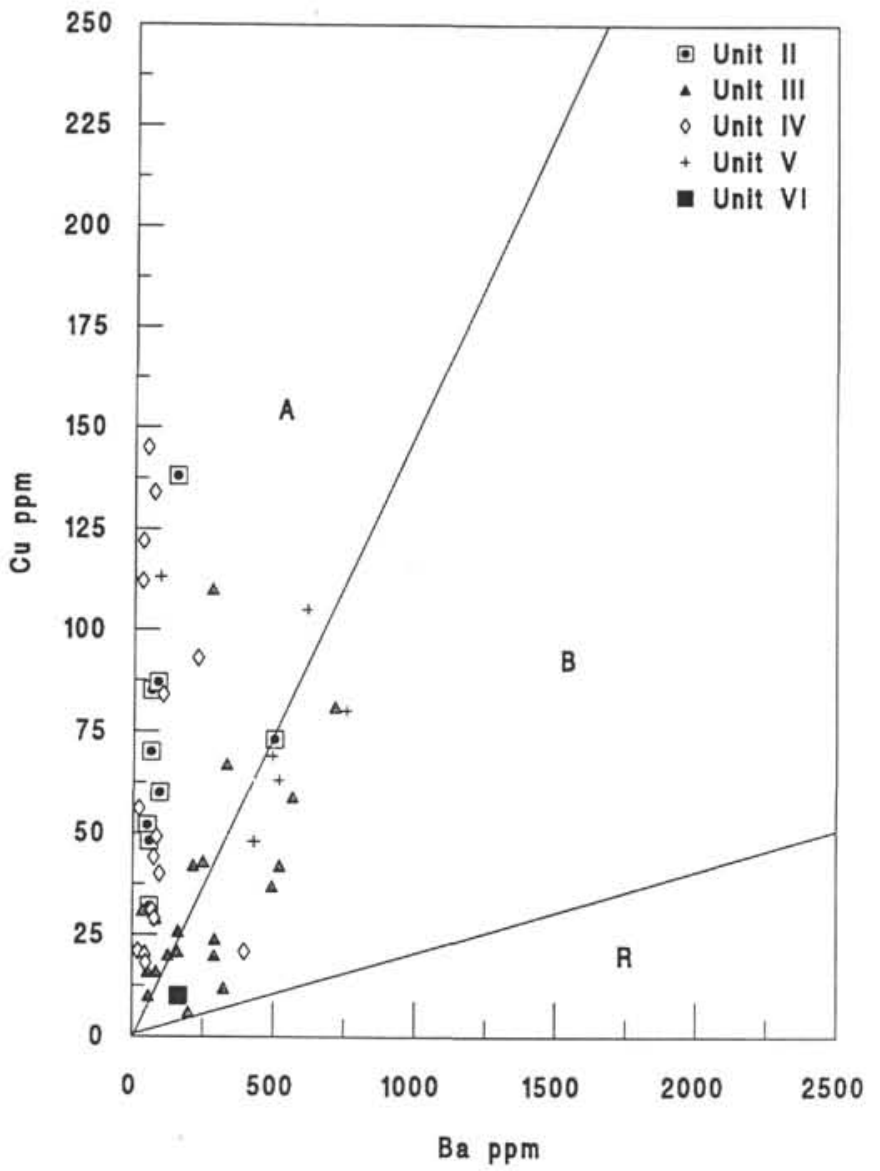

ODP SITE 801 (Cu ppm VERSUS Ba ppm)

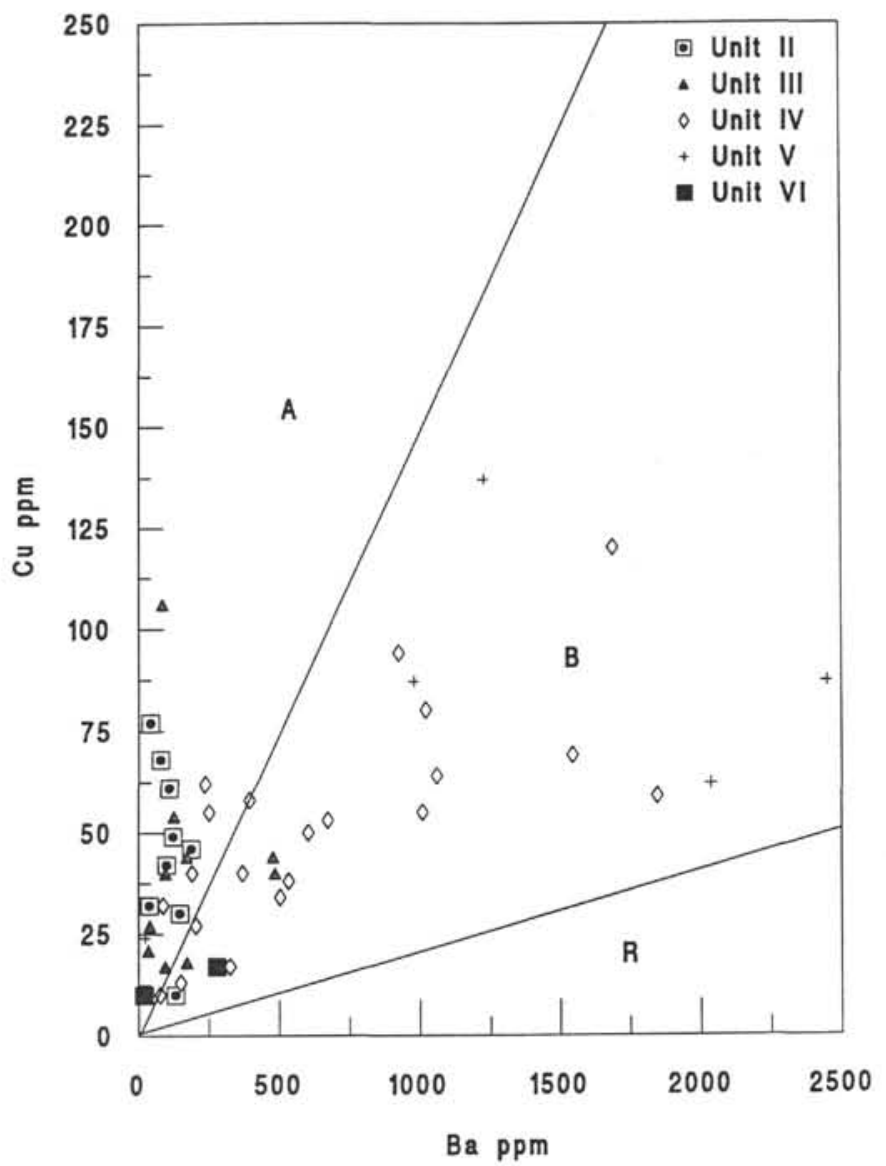

Figure 17. Plot of copper vs. barium for samples from Leg 129. Fields from Karl (1982). A = authigenic, $B=$ biogenic, $R=$ biogenic dissolution residue. 
ODP SITE 802 (Cu ppm VERSUS Ba ppm)

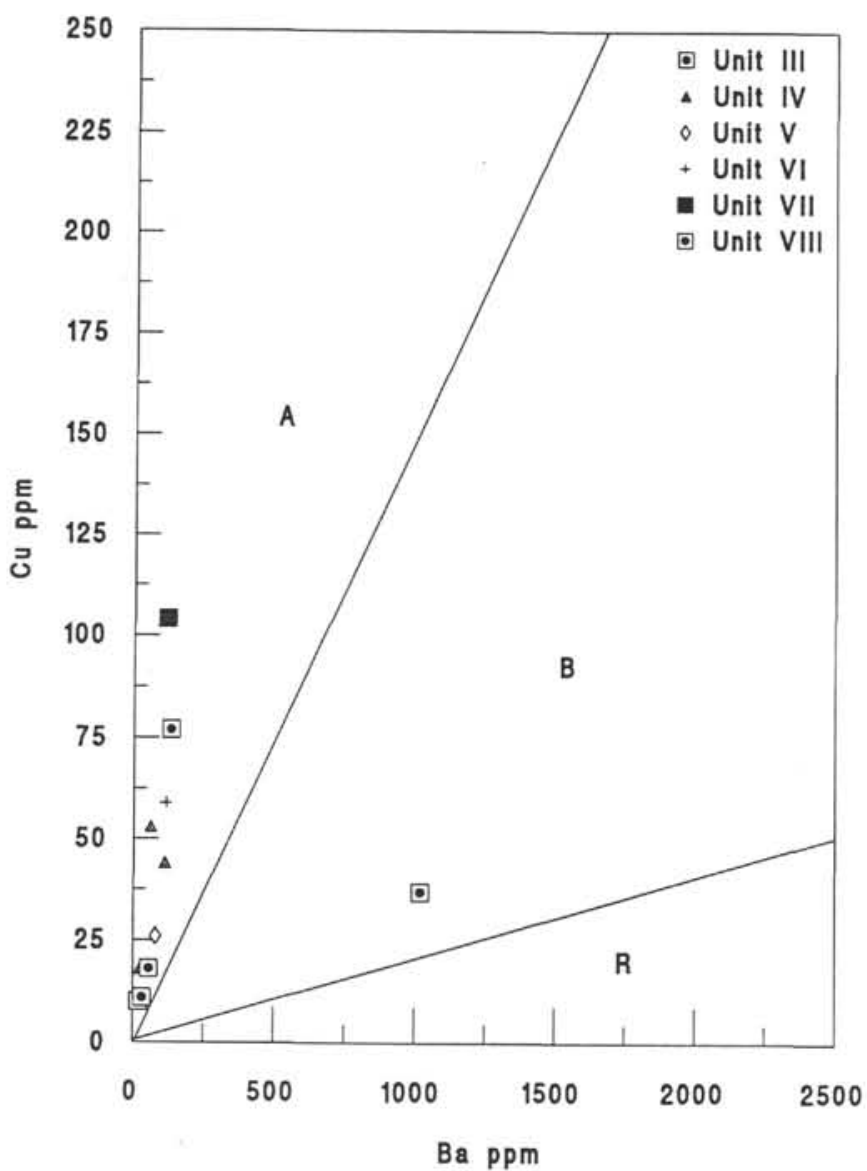

Figure 17 (continued).

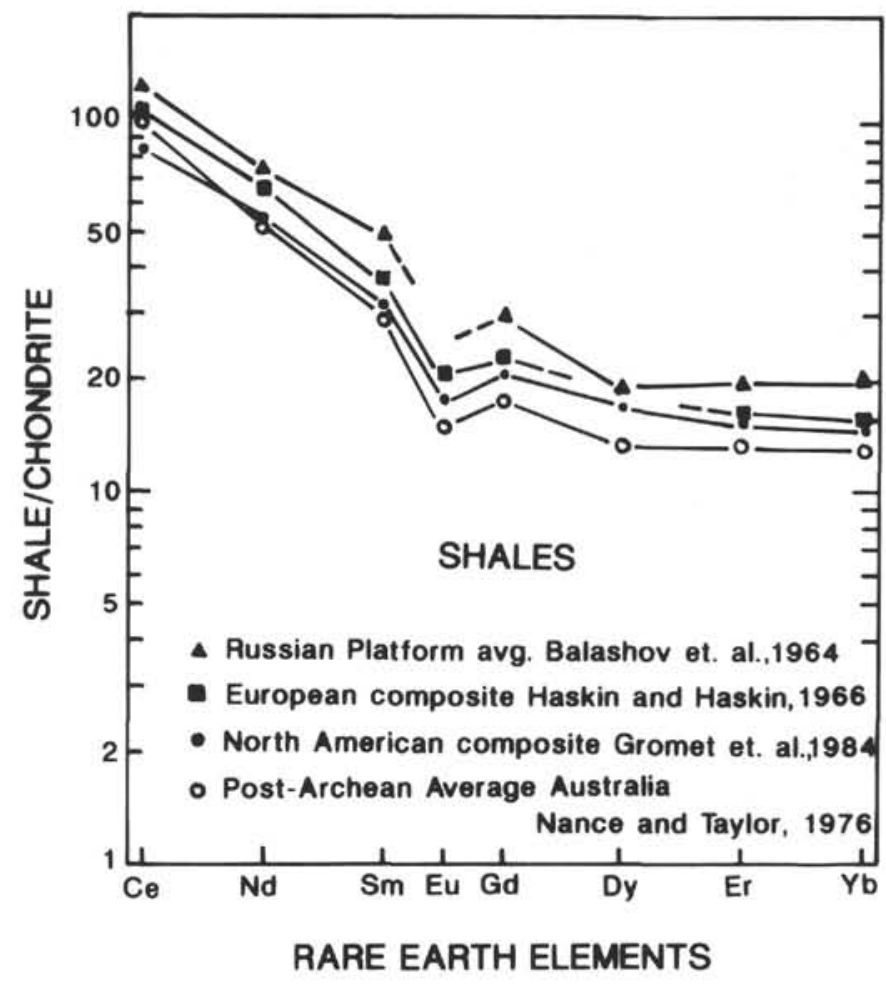

Figure 18. Distributions of REE for average shales, normalized to chondrite, from Gromet et al. (1984), sources of data in Gromet et al. (1984).

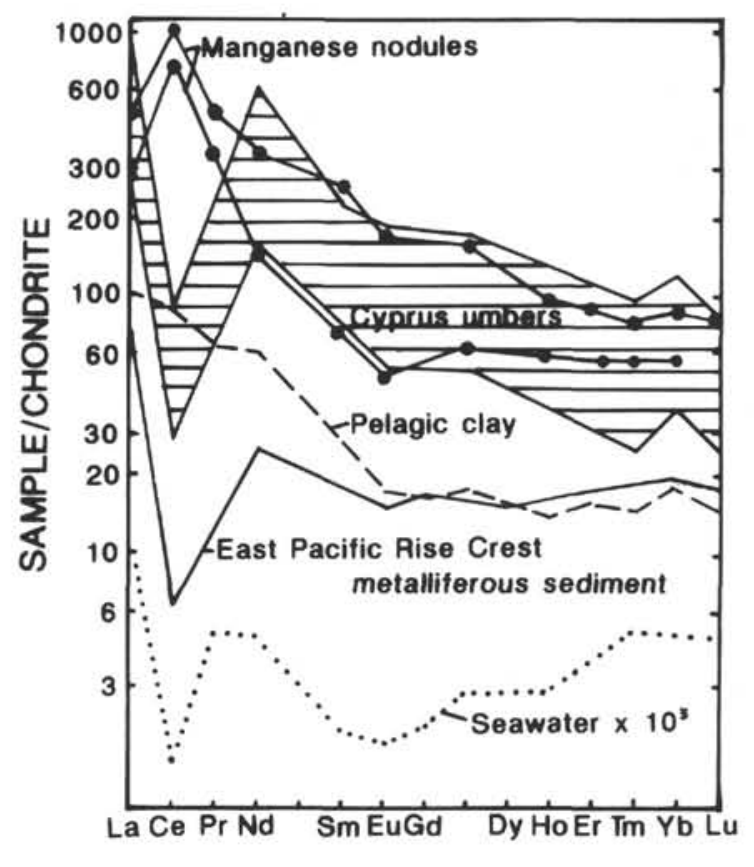

RARE EARTH ELEMENTS

Figure 19. Chondrite-normalized distributions of REE in seawater and oceanic sediments. Sources of data: EPR sediment from Bender et al. (1971); lower Mn nodule pattern from Bernat in Bonatti et al. (1976); higher Mn nodule pattern from Ehrlich in Robertson and Fleet (1976); clay and seawater patterns from Haskin et al. in Robertson and Fleet (1976); Cyprus umbers pattern from Robertson and Fleet (1976). 

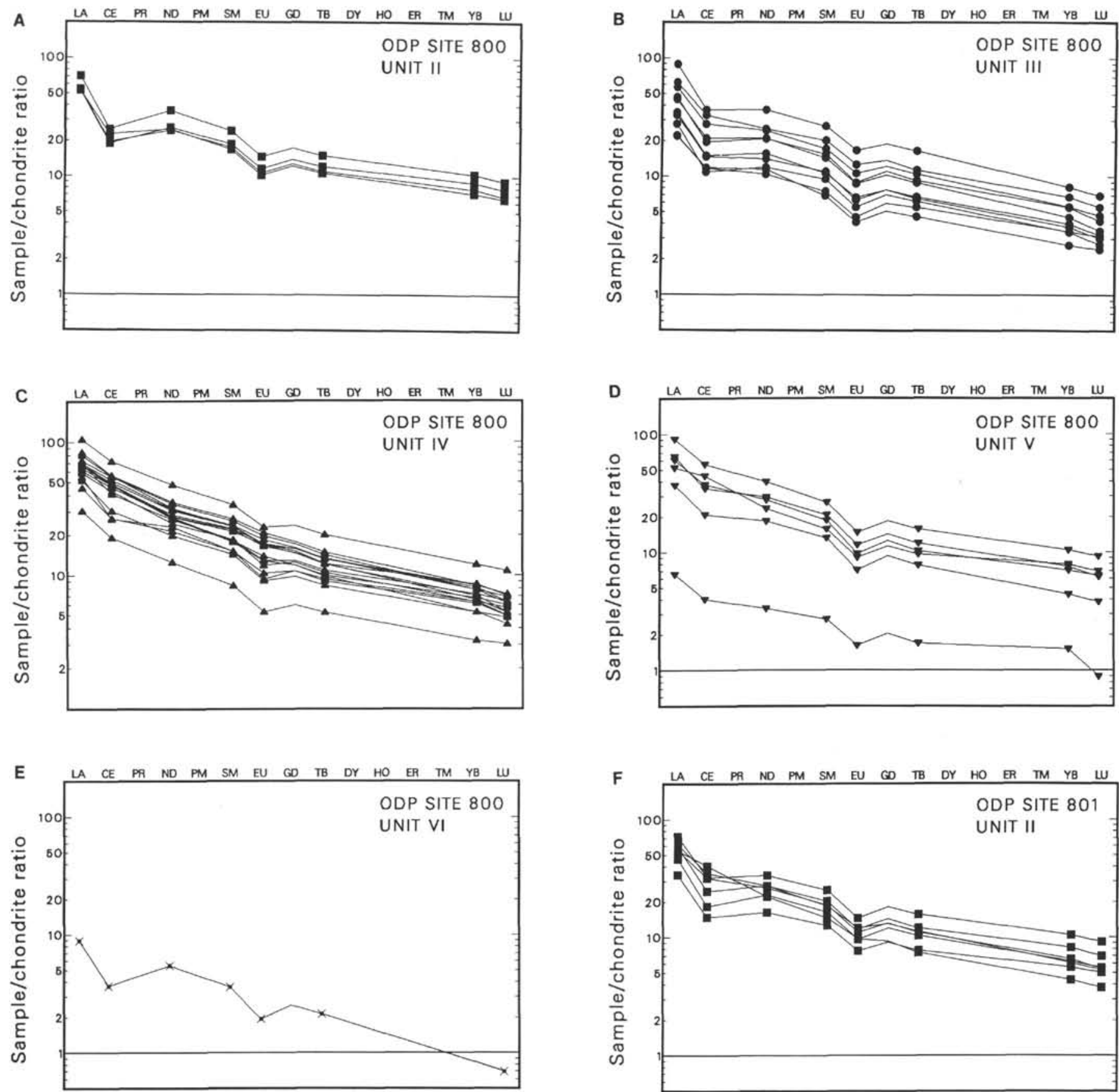

Figure 20. Chondrite-normalized (chondrite values of Anders and Ebihara, 1982) rare earth element plots for Leg 129 samples. A. Site 800, Unit II. B. Site 800, Unit III. C. Site 800, Unit IV. D. Site 800, Unit V. E. Site 800, Unit VI. F. Site 801, Unit II. G. Site 801, Unit III. H. Site 801, Unit IV. I. Site 801, Unit V. J. Site 801, Unit VI. K. Site 802, Unit III. L. Site 802, Unit IV. M. Site 802, Unit V. N. Site 802, Unit VI. O. Site 802, Unit VII. P. Site 802, Unit VIII. 

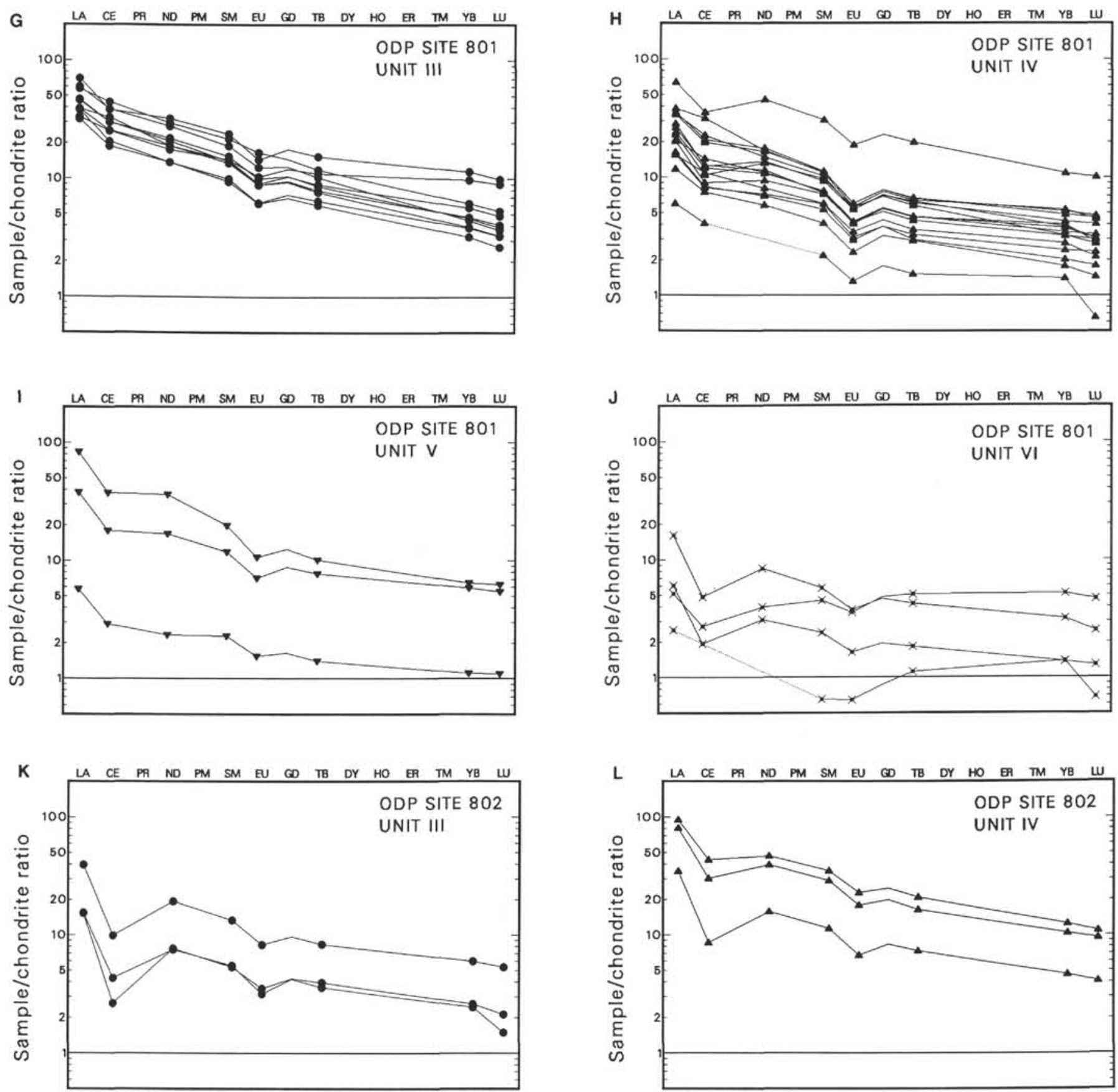

Figure 20 (continued). 
S. M. KARL, G. A. WANDLESS, A. M. KARPOFF
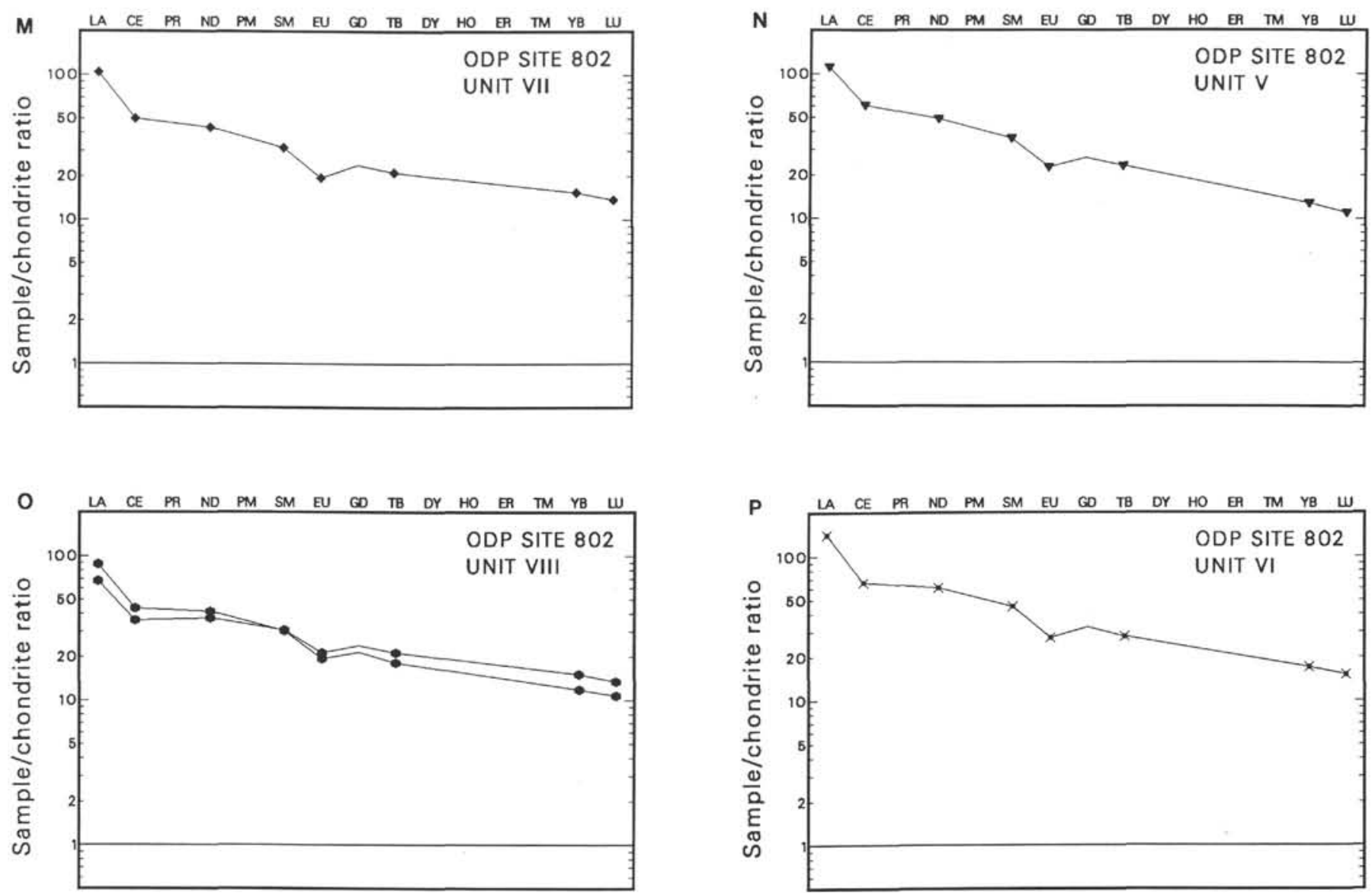

Figure 20 (continued). 
[BLANK PAGE] 
APPENDIX A

Table A1. Major element oxide data (in percent) for samples from Site 800, Leg 129.

\begin{tabular}{|c|c|c|c|c|c|c|c|c|c|c|c|c|c|}
\hline Sample $(\mathrm{cm})$ & $\begin{array}{l}\text { Depth } \\
\text { (mbsf) }\end{array}$ & $\mathrm{SiO}_{2}$ & $\mathrm{Al}_{2} \mathrm{O}_{3}$ & $\mathrm{FeTO}_{3}$ & $\mathrm{MgO}$ & $\mathrm{CaO}$ & $\mathrm{Na}_{2} \mathrm{O}$ & $\mathrm{K}_{2} \mathrm{O}$ & $\mathrm{TiO}_{2}$ & $\mathrm{P}_{2} \mathrm{O}_{5}$ & $\mathrm{MnO}$ & LOI $925 \mathrm{C}$ & $\begin{array}{c}\text { Oxide } \\
\text { total }\end{array}$ \\
\hline \multicolumn{14}{|l|}{ 129-800A- } \\
\hline 6R-1, 67-69 & 40.2 & 87.30 & 2.34 & 1.02 & 0.58 & 0.41 & 0.46 & 0.48 & 0.09 & 0.26 & 0.16 & 5.77 & 98.87 \\
\hline $7 R-1,2-5$ & 49.2 & 89.30 & 1.80 & 0.84 & 0.52 & 0.35 & 0.38 & 0.37 & 0.07 & 0.23 & 0.14 & 5.04 & 99.04 \\
\hline $8 R-1,48-50$ & 59.4 & 87.60 & 2.05 & 1.54 & 0.64 & 0.29 & 0.44 & 0.48 & 0.11 & 0.18 & 0.29 & 5.46 & 99.08 \\
\hline $9 \mathrm{R}-1,30-33$ & 68.8 & 86.60 & 2.19 & 1.86 & 0.78 & 0.24 & 0.44 & 0.56 & 0.13 & 0.15 & 0.49 & 5.63 & 99.07 \\
\hline $10 \mathrm{R}-1,13-17$ & 78.3 & 89.60 & 1.60 & 1.44 & 0.41 & 0.11 & 0.34 & 0.46 & 0.10 & 0.07 & 0.02 & 4.58 & 98.73 \\
\hline 1IR-1.7-10 & 87.9 & 82.80 & 2.16 & 1.34 & 0.68 & 3.48 & 0.38 & 0.67 & 0.13 & 0.06 & 0.02 & 7.44 & 99.16 \\
\hline $12 \mathrm{R}-1,30-32$ & 97.6 & 85.60 & 2.76 & 1.59 & 0.80 & 0.23 & 0.48 & 0.86 & 0.17 & 0.10 & 0.02 & 5.63 & 98.24 \\
\hline $13 \mathrm{R}-1,12-14$ & 106.9 & 89.80 & 1.69 & 1.34 & 0.64 & 0.11 & 0.32 & 0.58 & 0.10 & 0.07 & 0.02 & 4.09 & 98.76 \\
\hline $14 \mathrm{R}-1,110-115$ & 117.3 & 78.20 & 4.40 & 3.27 & 1.44 & 0.49 & 0.75 & 1.32 & 0.35 & 0.21 & 0.02 & 8.49 & 98.94 \\
\hline $17 \mathrm{R}-1,68-71$ & 144.9 & 85.20 & 2.77 & 1.69 & 0.83 & 0.25 & 0.58 & 0.75 & 0.22 & 0.09 & 0.02 & 6.59 & 98.99 \\
\hline $18 \mathrm{R}-1,127-130$ & 155.0 & 88.90 & 1.88 & 1.19 & 0.59 & 0.17 & 0.40 & 0.55 & 0.13 & 0.06 & 0.02 & 4.88 & 98.77 \\
\hline 23R-1, 69-70 & 201.2 & 83.90 & 2.80 & 2.43 & 0.98 & 0.50 & 0.71 & 0.74 & 0.25 & 0.16 & 0.02 & 6.50 & 98.99 \\
\hline $24 \mathrm{R}-1,68-71$ & 210.6 & 79.40 & 4.61 & 3.24 & 1.33 & 1.08 & 1.01 & 0.97 & 0.45 & 0.12 & 0.06 & 6.87 & 99.14 \\
\hline $24 \mathrm{R}-1,92-95$ & 210.8 & 90.40 & 1.57 & 1.18 & 0.49 & 0.27 & 0.41 & 0.33 & 0.16 & 0.08 & 0.02 & 3.96 & 98.87 \\
\hline $26 \mathrm{R}-1,22-26$ & 228.8 & 46,20 & 2.90 & 2.51 & 1.86 & 22.50 & 0.70 & 0.70 & 0.31 & 0.13 & 0.31 & 22.00 & 100.12 \\
\hline 26R-1, 135-139 & 230.0 & 55.00 & 6.77 & 5.93 & 3.55 & 8.91 & 1.84 & 2.55 & 1.03 & 0.19 & 0.15 & 13.80 & 99.72 \\
\hline $27 \mathrm{R}-1,61-64$ & 238.6 & 55.00 & 7.97 & 7.02 & 7.61 & 2.54 & 2.53 & 0.79 & 1.57 & 0.22 & 0.15 & 14.40 & 99.80 \\
\hline $27 \mathrm{R}-1,110-114$ & 239.1 & 72.80 & 3.58 & 3.37 & 1.65 & 4.50 & 0.84 & 0.84 & 0.39 & 0.09 & 0.11 & 11.40 & 99.57 \\
\hline $28 \mathrm{R}-3,106-110$ & 251.3 & 48.60 & 10.60 & 9.31 & 10.10 & 4.71 & 2.69 & 0.79 & 1.51 & 0.23 & 0.15 & 10.90 & 99.59 \\
\hline $30 \mathrm{R}-1,125-129$ & 267.2 & 75.60 & 5.43 & 4.69 & 1.77 & 0.91 & 1.25 & 0.79 & 0.64 & 0.12 & 0.06 & 8.13 & 99.39 \\
\hline $30 \mathrm{R}-2,114-118$ & 268.5 & 85.70 & 2.76 & 2.53 & 0.92 & 0.46 & 0.67 & 0.45 & 0.29 & 0.07 & 0.03 & 4.95 & 98.83 \\
\hline $31 \mathrm{R}-1,12-14$ & 272.1 & 74.00 & 5.93 & 4.09 & 1.80 & 0.94 & 1.54 & 1.27 & 0.51 & 0.14 & 0.05 & 9.04 & 99.31 \\
\hline $32 \mathrm{R}-\mathrm{CC}, 10-13$ & 280.8 & 70.00 & 6.88 & 5.53 & 2.07 & 1.33 & 1.56 & 0.93 & 0.80 & 0.17 & 0.08 & 9.86 & 99.21 \\
\hline $33 \mathrm{R}-7,14-18$ & 296.6 & 42.60 & 9.93 & 9.87 & 7.31 & 7.55 & 1.46 & 3.78 & 1.54 & 0.18 & 0.17 & 15.60 & 99.99 \\
\hline $34 \mathrm{R}-2,139-142$ & 299.9 & 42.30 & 7.95 & 7.57 & 12.50 & 7.33 & 1.66 & 2.36 & 0.90 & 0.30 & 0.15 & 16.80 & 99.82 \\
\hline $35 \mathrm{R}-3,84-88$ & 310.2 & 67.10 & 6.97 & 6.86 & 3.34 & 1.23 & 1.53 & 1.17 & 0.86 & 0.14 & 0.14 & 10.10 & 99.44 \\
\hline $36 \mathrm{R}-1,110-114$ & 317.0 & 40.60 & 9.59 & 8.97 & 6.99 & 9.69 & 1.41 & 2.83 & 1.48 & 0.25 & 0.25 & 18.00 & 100.06 \\
\hline $36 \mathrm{R}-4,28-32$ & 320.7 & 42.30 & 10.20 & 9.62 & 10.60 & 5.09 & 1.89 & 2.35 & 1.70 & 0.25 & 0.23 & 15.70 & 99.93 \\
\hline $41 \mathrm{R}-1,87-93$ & 363.4 & 43.30 & 8.52 & 9.87 & 9.78 & 6.55 & 1.82 & 1.38 & 1.49 & 0.32 & 0.24 & 16.90 & 100.17 \\
\hline $42 \mathrm{R}-1,41-43$ & 369.0 & 57.00 & 8.89 & 8.53 & 6.93 & 1.41 & 1.37 & 2.67 & 0.95 & 0.33 & 0.10 & 11.70 & 99.88 \\
\hline $44 \mathrm{R}-1,92-94$ & 384.6 & 44.50 & 9.28 & 11.50 & 10.80 & 2.85 & 1.78 & 1.41 & 1.77 & 0.41 & 0.20 & 15.50 & 100.00 \\
\hline 5IR-1, 106-108 & 450.7 & 80.20 & 5.27 & 3.33 & 1.55 & 0.58 & 0.71 & 1.39 & 0.34 & 0.15 & 0.09 & 5.55 & 99.16 \\
\hline $52 \mathrm{R}-1,16-20$ & 459.0 & 73.30 & 7.25 & 4.83 & 1.87 & 0.66 & 0.91 & 1.94 & 0.44 & 0.15 & 0.97 & 7.10 & 99.42 \\
\hline $53 \mathrm{R}-1,32-34$ & 465.2 & 81.00 & 4.22 & 3.54 & 1.37 & 0.59 & 0.77 & 1.13 & 0.27 & 0.16 & 0.47 & 5.40 & 98.92 \\
\hline $55 \mathrm{R}-1,76-81$ & 479.9 & 83.10 & 3.65 & 2.71 & 1.04 & 0.93 & 0.61 & 0.97 & 0.21 & 0.10 & 0.27 & 5.77 & 99.36 \\
\hline $55 \mathrm{R}-2,25-30$ & 480.9 & 79.80 & 5.33 & 3.26 & 1.36 & 0.54 & 0.80 & 1.55 & 0.28 & 0.15 & 0.34 & 5.61 & 99.02 \\
\hline $56 \mathrm{R}-1,8-13$ & 488.6 & 87.00 & 3.08 & 1.93 & 0.75 & 0.37 & 0.64 & 0.91 & 0.15 & 0.10 & 0.18 & 3.98 & 99.09 \\
\hline $58 \mathrm{R}-1,37-42$ & 507.2 & 95.70 & 0.57 & 0.35 & 0.14 & 0.05 & 0.15 & 0.20 & 0.02 & 0.05 & 0.04 & 1.32 & 98.59 \\
\hline
\end{tabular}

Note: Analyses obtained by X-ray fluorescence, U.S. Geological Survey laboratories. 
Table A2. Major element oxide data for (in percent) samples from Site 801, Leg 129.

\begin{tabular}{|c|c|c|c|c|c|c|c|c|c|c|c|c|c|}
\hline Sample (cm) & $\begin{array}{l}\text { Depth } \\
\text { (mbsf) }\end{array}$ & $\mathrm{SiO}_{2}$ & $\mathrm{Al}_{2} \mathrm{O}_{3}$ & $\mathrm{FeTO}_{3}$ & $\mathrm{MgO}$ & $\mathrm{CaO}$ & $\mathrm{Na}_{2} \mathrm{O}$ & $\mathrm{K}_{2} \mathrm{O}$ & $\mathrm{TiO}_{2}$ & $\mathrm{P}_{2} \mathrm{O}_{5}$ & $\mathrm{MnO}$ & LOI $925 \mathrm{C}$ & $\begin{array}{c}\text { Oxide } \\
\text { total }\end{array}$ \\
\hline \multicolumn{14}{|l|}{ 129-801A- } \\
\hline $8 \mathrm{R}-1,1-3$ & 60.6 & 96.7 & 0.4 & 0.3 & 0.10 & 0.05 & 0.15 & 0.13 & 0.02 & 0.05 & 0.04 & 0.84 & 98.74 \\
\hline $9 \mathrm{R}-1,0-3$ & 70.2 & 83.9 & 3.4 & 1.5 & 0.80 & 0.37 & 0.63 & 0.77 & 0.15 & 0.23 & 0.18 & 6.74 & 98.71 \\
\hline $10 R-1,0-5$ & 79.5 & 89.8 & 1.6 & 0.9 & 0.43 & 0.22 & 0.35 & 0.33 & 0.10 & 0.14 & 0.08 & 4.79 & 98.71 \\
\hline $12 \mathrm{R}-1,22-25$ & 99.0 & 76.3 & 5.4 & 3.8 & 1.30 & 0.46 & 1.23 & 1.17 & 0.62 & 0.13 & 0.33 & 8.45 & 99.27 \\
\hline $80-100 \mathrm{M}$ & 100.0 & 82.8 & 3.5 & 1.9 & 0.90 & 0.42 & 0.73 & 0.76 & 0.24 & 0.24 & 0.18 & 7.00 & 98.72 \\
\hline $13 \mathrm{R}-1,21-26$ & 108.7 & 84.1 & 3.4 & 2.0 & 0.97 & 0.36 & 0.61 & 0.76 & 0.25 & 0.12 & 0.09 & 6.43 & 99.05 \\
\hline $14 \mathrm{R}-1,26-28$ & 118.5 & 86.0 & 2.7 & 1.9 & 0.92 & 0.47 & 0.49 & 0.75 & 0.18 & 0.10 & 0.03 & 5.56 & 99.03 \\
\hline $15 \mathrm{R}-1,24-26$ & 128.1 & 79.6 & 3.9 & 4.0 & 1.29 & 0.60 & 0.96 & 0.97 & 0.67 & 0.13 & 0.05 & 6.95 & 99.09 \\
\hline $16 \mathrm{R}-1,135-138$ & 139.0 & 75.4 & 4.7 & 4.2 & 1.82 & 0.94 & 1.19 & 1.58 & 0.89 & 0.19 & 0.04 & 8.47 & 99.40 \\
\hline $17 \mathrm{R}-1,28-30$ & 147.5 & 78.9 & 4.1 & 3.6 & 1.71 & 0.50 & 0.88 & 1.47 & 0.45 & 0.11 & 0.04 & 6.77 & 98.56 \\
\hline $18 \mathrm{R}-2,14-17$ & 158.6 & 76.9 & 4.6 & 4.0 & 2.18 & 0.54 & 0.95 & 1.81 & 0.53 & 0.11 & 0.04 & 7.21 & 98.79 \\
\hline 19R-CC, 12-16 & 176.3 & 82.9 & 2.6 & 2.6 & 1.22 & 1.23 & 0.64 & 0.87 & 0.40 & 0.09 & 0.02 & 6.21 & 98.85 \\
\hline $20 \mathrm{R}-1,8-12$ & 176.5 & 88.6 & 1.7 & 1.6 & 0.74 & 0.36 & 0.48 & 0.60 & 0.27 & 0.09 & 0.02 & 4.38 & 98.88 \\
\hline \multicolumn{14}{|l|}{$129-801 \mathrm{~B}-$} \\
\hline $8 R-2,60-63$ & 254.8 & 89.5 & 1.8 & 1.4 & 0.61 & 0.27 & 0.48 & 0.49 & 0.20 & 0.08 & 0.02 & 3.99 & 98.80 \\
\hline 10R-1, 70-73 & 272.7 & 58.0 & 8.1 & 9.2 & 5.42 & 1.34 & 2.01 & 2.41 & 1.69 & 0.26 & 0.13 & 11.10 & 99.71 \\
\hline $11 \mathrm{R}-1,31-36$ & 282.0 & 77.1 & 5.3 & 4.4 & 1.09 & 0.58 & 1.17 & 1.17 & 0.56 & 0.10 & 0.12 & 7.45 & 99.08 \\
\hline $12 \mathrm{R}-1,64-70$ & 292.0 & 77.4 & 3.7 & 6.3 & 2.30 & 0.49 & 0.66 & 2.53 & 0.39 & 0.17 & 0.08 & 5.38 & 99.42 \\
\hline $14 \mathrm{R}-1,52-57$ & 310.8 & 85.2 & 3.2 & 2.2 & 0.84 & 0.29 & 0.72 & 0.79 & 0.18 & 0.08 & 0.32 & 5.05 & 98.88 \\
\hline $15 \mathrm{R}-1,19-20$ & 319.9 & 82.9 & 4.2 & 2.3 & 0.99 & 0.27 & 0.73 & 1.07 & 0.23 & 0.09 & 0.46 & 6.10 & 99.34 \\
\hline $16 \mathrm{R}-1,40-43$ & 329.6 & 93.1 & 1.2 & 0.7 & 0.24 & 0.10 & 0.23 & 0.28 & 0.05 & 0.05 & 0.10 & 2.59 & 98.64 \\
\hline $17 \mathrm{R}-1,34-36$ & 338.9 & 92.4 & 1.4 & 0.9 & 0.25 & 0.12 & 0.23 & 0.34 & 0.07 & 0.08 & 0.18 & 3.02 & 99.03 \\
\hline $18 \mathrm{R}-1,37-40$ & 348.2 & 91.0 & 1.8 & 0.9 & 0.32 & 0.23 & 0.32 & 0.42 & 0.07 & 0.08 & 0.19 & 3.33 & 98.66 \\
\hline $19 \mathrm{R}-1,24-26$ & 357.5 & 95.5 & 0.5 & 0.2 & 0.10 & 0.05 & 0.15 & 0.11 & 0.02 & 0.05 & 0.05 & 1.79 & 98.60 \\
\hline $20 \mathrm{R}-1,23-26$ & 366.7 & 91.8 & 1.6 & 1.2 & 0.27 & 0.11 & 0.27 & 0.41 & 0.06 & 0.06 & 0.15 & 2.73 & 98.62 \\
\hline $21 \mathrm{R}-1,12-13$ & 375.8 & 92.8 & 1.4 & 2.0 & 0.27 & 0.11 & 0.17 & 0.34 & 0.05 & 0.05 & 0.22 & 2.70 & 100.04 \\
\hline $24 \mathrm{R}-1,69-73$ & 393.3 & 90.7 & 2.0 & 1.4 & 0.43 & 0.10 & 0.31 & 0.49 & 0.09 & 0.05 & 0.31 & 3.16 & 98.99 \\
\hline $25 \mathrm{R}-1,49-53$ & 397.7 & 84.7 & 3.7 & 2.2 & 0.85 & 0.20 & 0.71 & 0.98 & 0.18 & 0.05 & 0.40 & 4.65 & 98.62 \\
\hline $27 \mathrm{R}-1,104-107$ & 407.7 & 93.7 & 1.0 & 0.9 & 0.16 & 0.07 & 0.19 & 0.28 & 0.04 & 0.05 & 0.21 & 2.14 & 98.73 \\
\hline $29 \mathrm{R}-1,17-19$ & 416.4 & 92.7 & 1.4 & 1.1 & 0.26 & 0.15 & 0.23 & 0.37 & 0.06 & 0.08 & 0.28 & 2.94 & 99.54 \\
\hline $31 \mathrm{R}-1,18-20$ & 425.8 & 92.8 & 1.4 & 1.0 & 0.27 & 0.15 & 0.24 & 0.39 & 0.07 & 0.08 & 0.12 & 2.82 & 99.32 \\
\hline $33 \mathrm{R}-1,10-14$ & 434.9 & 68.7 & 6.3 & 10.3 & 1.45 & 0.37 & 0.89 & 2.15 & 0.39 & 0.20 & 0.06 & 7.04 & 97.80 \\
\hline $33 \mathrm{R}-1,126-129$ & 436.1 & 83.7 & 4.0 & 3.7 & 0.96 & 0.18 & 0.64 & 1.25 & 0.26 & 0.05 & 0.02 & 4.81 & 99.56 \\
\hline $35 \mathrm{R}-1,51-55$ & 444.8 & 64.6 & 8.4 & 9.9 & 2.06 & 0.36 & 1.07 & 2.77 & 0.60 & 0.09 & 0.11 & 9.12 & 99.15 \\
\hline $35 \mathrm{R}-1,123-127$ & 445.5 & 74.5 & 5.2 & 8.3 & 1.38 & 0.26 & 0.78 & 1.64 & 0.36 & 0.12 & 0.07 & 6.86 & 99.42 \\
\hline $37 \mathrm{R}-1,7-10$ & 453.6 & 91.8 & 0.6 & 3.3 & 0.27 & 0.05 & 0.15 & 0.29 & 0.03 & 0.05 & 0.05 & 1.95 & 98.51 \\
\hline $39 \mathrm{R}-1,4-7$ & 462.7 & 94.8 & 0.7 & 1.7 & 0.15 & 0.12 & 0.15 & 0.22 & 0.04 & 0.10 & 0.15 & 0.96 & 99.13 \\
\hline \multicolumn{14}{|l|}{$129-801 C-$} \\
\hline $4 \mathrm{R}-1,11-16$ & 521.8 & 81.1 & 0.1 & 15.7 & 0.10 & 0.02 & 0.15 & 0.02 & 0.02 & 0.06 & 0.02 & 2.66 & 99.95 \\
\hline $5 R-4,11-16$ & 535.8 & 11.4 & 0.5 & 3.9 & 6.32 & 39.30 & 0.15 & 0.23 & 0.02 & 0.05 & 0.39 & 38.40 & 100.60 \\
\hline $6 \mathrm{R}-1,31-34$ & 540.8 & 5.3 & 0.9 & 7.5 & 5.88 & 39.90 & 0.15 & 0.03 & 0.02 & 0.08 & 0.63 & 40.30 & 100.62 \\
\hline
\end{tabular}

Note: Analyses obtained by X-ray fluorescence, U.S. Geological Survey laboratories.

Table A3. Major element oxide data (in percent) for samples from Site 802, Leg 129.

\begin{tabular}{|c|c|c|c|c|c|c|c|c|c|c|c|c|c|}
\hline Sample $(\mathrm{cm})$ & $\begin{array}{l}\text { Depth } \\
\text { (mbsf) }\end{array}$ & $\mathrm{SiO}_{2}$ & $\mathrm{Al}_{2} \mathrm{O}_{3}$ & $\mathrm{FeTO}_{3}$ & $\mathrm{MgO}$ & $\mathrm{CaO}$ & $\mathrm{Na}_{2} \mathrm{O}$ & $\mathrm{K}_{2} \mathrm{O}$ & $\mathrm{TiO}_{2}$ & $\mathrm{P}_{2} \mathrm{O}_{5}$ & $\mathrm{MnO}$ & LOI $925 \mathrm{C}$ & $\begin{array}{c}\text { Oxide } \\
\text { total }\end{array}$ \\
\hline \multicolumn{14}{|l|}{$129-802 \mathrm{~A}-$} \\
\hline $33 \mathrm{R}-1,116-120$ & 294.0 & 45.5 & 1.03 & 0.48 & 0.67 & 27.30 & 0.33 & 0.14 & 0.05 & 0.15 & 0.14 & 24.30 & 100.09 \\
\hline $34 \mathrm{R}-1,128-132$ & 303.6 & 95.8 & 0.19 & 0.07 & 0.10 & 0.25 & 0.15 & 0.04 & 0.02 & 0.07 & 0.02 & 1.90 & 98.61 \\
\hline $35 \mathrm{R}-\mathrm{CC}, 0-4$ & 320.5 & 94.8 & 0.47 & 0.20 & 0.10 & 0.10 & 0.15 & 0.11 & 0.02 & 0.06 & 0.02 & 2.23 & 98.26 \\
\hline $37 R-1,11-15$ & 330.0 & 88.9 & 0.80 & 0.39 & 0.18 & 2.93 & 0.24 & 0.15 & 0.07 & 0.10 & 0.02 & 5.25 & 99.03 \\
\hline $38 \mathrm{R}-\mathrm{CC}, 12-15$ & 348.6 & 65.4 & 6.45 & 5.18 & 1.72 & 3.77 & 1.45 & 1.10 & 1.16 & 0.29 & 0.09 & 13.00 & 99.61 \\
\hline $39 \mathrm{R}-1,10-15$ & 348.8 & 70.0 & 4.55 & 4.13 & 1.07 & 4.82 & 1.10 & 0.75 & 0.96 & 0.18 & 0.06 & 11.90 & 99.52 \\
\hline $43 R-1,75-78$ & 382.9 & 77.8 & 4.72 & 3.22 & 1.71 & 0.92 & 0.80 & 1.45 & 0.31 & 0.36 & 0.04 & 8.11 & 99.44 \\
\hline $52 \mathrm{R}-2,125-130$ & 462.6 & 73.2 & 7.08 & 3.83 & 1.80 & 1.04 & 1.22 & 1.61 & 0.45 & 0.36 & 0.19 & 8.90 & 99.68 \\
\hline $55 \mathrm{R}-1,138-141$ & 489.3 & 76.3 & 5.89 & 3.95 & 1.69 & 0.91 & 1.01 & 1.47 & 0.44 & 0.27 & 0.23 & 7.26 & 99.42 \\
\hline $56 \mathrm{R}-1,43-47$ & 497.5 & 70.7 & 7.93 & 4.84 & 1.66 & 1.23 & 1.58 & 1.75 & 0.76 & 0.22 & 0.24 & 8.29 & 99.20 \\
\hline $56 \mathrm{R}-2,88-92$ & 499.5 & 78.8 & 3.71 & 5.46 & 1.45 & 0.78 & 0.69 & 1.42 & 0.24 & 0.24 & 0.05 & 6.48 & 99.32 \\
\hline
\end{tabular}

Note: Analyses obtained by X-ray fluorescence, U.S. Geological Survey laboratories. 
APPENDIX B

Table B1. Minor element analyses (in parts per million) for samples from Site 800, Leg 129.

\begin{tabular}{|c|c|c|c|c|c|c|c|c|c|c|c|c|c|}
\hline Sample $(\mathrm{cm})$ & $\begin{array}{l}\text { Depth } \\
\text { (mbsf) }\end{array}$ & $\mathrm{Ba}$ & $\mathrm{Cr}$ & $\mathrm{Cu}$ & $\mathrm{Ni}$ & $\mathrm{Rb}$ & $\mathrm{Sr}$ & $\mathrm{Zn}$ & $\mathrm{Zr}$ & $\mathrm{Y}$ & $\mathrm{La}$ & $\mathrm{Ce}$ & B \\
\hline \multicolumn{14}{|l|}{$129-800 \mathrm{~A}=$} \\
\hline $6 \mathrm{R}-1,67-69$ & 40.2 & 61 & 20 & 70 & 32 & 17 & 35 & 47 & 35 & 35 & 28 & 20 & 54 \\
\hline $7 \mathrm{R}-1,2-5$ & 49.2 & 51 & 20 & 52 & 22 & 11 & 29 & 38 & 33 & 29 & 24 & 16 & 41 \\
\hline $8 \mathrm{R}-1,48-50$ & 59.4 & 93 & 20 & 60 & 48 & 15 & 33 & 42 & 38 & 24 & 20 & 15 & 49 \\
\hline $9 \mathrm{R}-1,30-33$ & 68.8 & 500 & 20 & 73 & 37 & 18 & 37 & 44 & 39 & 22 & 16 & 19 & 52 \\
\hline $10 \mathrm{R}-1,13-17$ & 78.3 & 331 & 20 & 67 & 28 & 13 & 19 & 43 & 32 & 9 & 10 & 15 & 33 \\
\hline $11 \mathrm{R}-1,7-10$ & 87.9 & 162 & 20 & 26 & 23 & 22 & 76 & 27 & 37 & 13 & 16 & 16 & 45 \\
\hline $12 \mathrm{R}-1,30-32$ & 97.6 & 292 & 20 & 24 & 19 & 30 & 31 & 38 & 43 & 20 & 13 & 11 & 45 \\
\hline $13 \mathrm{R}-1,12-14$ & 106.9 & 54 & 20 & 16 & 19 & 17 & 18 & 30 & 33 & 14 & 12 & 10 & 39 \\
\hline $14 \mathrm{R}-1,110-115$ & 117.3 & 277 & 42 & 110 & 40 & 43 & 58 & 42 & 71 & 31 & 35 & 34 & 63 \\
\hline $17 \mathrm{R}-1.68-71$ & 144.9 & 72 & 20 & 31 & 36 & 25 & 43 & 40 & 54 & 18 & 18 & 21 & 53 \\
\hline $18 \mathrm{R}-1,127-130$ & 155.0 & 58 & 20 & 10 & 39 & 13 & 24 & 25 & 34 & 9 & 10 & 10 & 34 \\
\hline 23R-1, 69-70 & 201.2 & 45 & 20 & 21 & 23 & 19 & 80 & 22 & 54 & 20 & 22 & 23 & 39 \\
\hline $24 \mathrm{R}-1,68-71$ & 210.6 & 250 & 20 & 43 & 33 & 31 & 170 & 58 & 81 & 20 & 24 & 28 & 56 \\
\hline $24 \mathrm{R}-1,92-95$ & 210.8 & 35 & 20 & 31 & 17 & 10 & 37 & 26 & 35 & 15 & 15 & 20 & 34 \\
\hline $26 \mathrm{R}-1,22-26$ & 228.8 & 396 & 20 & 21 & 22 & 20 & 228 & 25 & 49 & 16 & 15 & 20 & 63 \\
\hline $26 \mathrm{R}-1,135-139$ & 230.0 & 103 & 170 & 84 & 56 & 48 & 616 & 49 & 96 & 11 & 27 & 42 & 21 \\
\hline $27 R-1,61-64$ & 238.6 & 45 & 196 & 145 & 79 & 22 & 571 & 73 & 137 & 15 & 31 & 48 & 19 \\
\hline $27 \mathrm{R}-1,110-114$ & 239.1 & 44 & 26 & 20 & 35 & 22 & 119 & 32 & 61 & 15 & 19 & 27 & 35 \\
\hline $28 \mathrm{R}-3,106-110$ & 251.3 & 226 & 658 & 93 & 326 & 18 & 390 & 84 & 136 & 18 & 24 & 39 & 16 \\
\hline $30 \mathrm{R}-1,125-129$ & 267.2 & 75 & 41 & 44 & 50 & 22 & 221 & 69 & 92 & 14 & 18 & 23 & 48 \\
\hline $30 \mathrm{R}-2,114-118$ & 268.5 & 47 & 20 & 18 & 20 & 10 & 95 & 32 & 44 & 9 & 11 & 19 & 30 \\
\hline $31 \mathrm{R}-1,12-14$ & 272.1 & 77 & 30 & 29 & 26 & 37 & 365 & 37 & 82 & 17 & 27 & 42 & 36 \\
\hline $32 \mathrm{R}-\mathrm{CC}, 10-13$ & 280.8 & 94 & 35 & 40 & 54 & 21 & 245 & 82 & .122 & 15 & 26 & 42 & 67 \\
\hline $33 \mathrm{R}-7,14-18$ & 296.6 & 69 & 355 & 134 & 150 & 45 & 121 & 81 & 146 & 19 & 29 & 49 & 47 \\
\hline $34 \mathrm{R}-2,139-142$ & 299.9 & 42 & 296 & 277 & 322 & 28 & 130 & 67 & 97 & 22 & 29 & 43 & 34 \\
\hline $35 \mathrm{R}-3,84-88$ & 310.2 & 70 & 70 & 31 & 65 & 38 & 217 & 73 & 112 & 21 & 25 & 36 & 45 \\
\hline $36 \mathrm{R}-1,110-114$ & 317.0 & 29 & 367 & 112 & 174 & 30 & 122 & 81 & 133 & 19 & 29 & 46 & 44 \\
\hline $36 R-4,28-32$ & 320.7 & 31 & 610 & 122 & 241 & 18 & 124 & 87 & 139 & 19 & 26 & 47 & 34 \\
\hline $41 R-1.87-93$ & 363.4 & 22 & 573 & 56 & 242 & 21 & 136 & 77 & 112 & 19 & 26 & 39 & 31 \\
\hline $42 \mathrm{R}-1,41-43$ & 369.0 & 85 & 266 & 49 & 144 & 73 & 131 & 94 & 110 & 33 & 39 & 60 & 51 \\
\hline $44 \mathrm{R}-1,92-94$ & 384.6 & 20 & 539 & 21 & 260 & 18 & 136 & 93 & 135 & 21 & 31 & 48 & 32 \\
\hline 51R-1, 106-108 & 450.7 & 91 & 20 & 113 & 44 & 50 & 70 & 76 & 73 & 21 & 17 & 41 & 41 \\
\hline $52 \mathrm{R}-1,16-20$ & 459.0 & 615 & 20 & 105 & 79 & 72 & 122 & 126 & 108 & 28 & 25 & 44 & 48 \\
\hline $53 \mathrm{R}-1,32-34$ & 465.2 & 493 & 20 & 69 & 45 & 44 & 94 & 82 & 64 & 19 & 18 & 29 & 33 \\
\hline $55 \mathrm{R}-1,76-81$ & 479.9 & 516 & 20 & 63 & 39 & 38 & 68 & 64 & 56 & 14 & 11 & 21 & 32 \\
\hline $55 \mathrm{R}-2,25-30$ & 480.9 & 754 & 20 & 80 & 41 & 60 & 74 & 71 & 70 & 20 & 17 & 31 & 43 \\
\hline $56 \mathrm{R}-1.8-13$ & 488.6 & 429 & 20 & 48 & 20 & 37 & 53 & 42 & 46 & 13 & 14 & 21 & 28 \\
\hline $58 \mathrm{R}-1,37-42$ & 507.2 & 164 & 20 & 10 & 12 & 10 & 10 & 22 & 16 & 5 & 10 & 10 & 22 \\
\hline
\end{tabular}

Note: Analyses obtained by X-ray spectroscopy, and by mass spectrometer for B, U.S. Geological Survey laboratories. 
Table B2. Minor element analyses (in parts per million) for samples from Site 801, Leg 129.

\begin{tabular}{|c|c|c|c|c|c|c|c|c|c|c|c|c|c|}
\hline Sample (cm) & $\begin{array}{l}\text { Depth } \\
\text { (mbsf) }\end{array}$ & $\mathrm{Ba}$ & $\mathrm{Cr}$ & $\mathrm{Cu}$ & $\mathrm{Ni}$ & $\mathrm{Rb}$ & $\mathrm{Sr}$ & $\mathrm{Zn}$ & $\mathrm{Zr}$ & $\mathrm{Y}$ & $\mathrm{La}$ & $\mathrm{Ce}$ & B \\
\hline \multicolumn{14}{|l|}{ 129-801A- } \\
\hline $8 \mathrm{R}-1,1-3$ & 60.6 & 131 & 20 & 10 & 10 & 10 & 10 & 19 & 14 & 5 & 10 & 10 & 8.4 \\
\hline $9 \mathrm{R}-1,0-3$ & 70.2 & 78 & 20 & 68 & 38 & 33 & 43 & 49 & 49 & 35 & 30 & 32 & 65 \\
\hline $10 \mathrm{R}-1,0-5$ & 79.5 & 38 & 20 & 32 & 14 & 11 & 24 & 30 & 35 & 20 & 11 & 10 & 31 \\
\hline $12 \mathrm{R}-1,22-25$ & 99.0 & 188 & 20 & 46 & 38 & 28 & 110 & 64 & 123 & 15 & 21 & 43 & 69 \\
\hline $80-100 \mathrm{M}$ & 100.0 & 109 & 20 & 61 & 30 & 29 & 47 & 58 & 57 & 29 & 26 & 24 & 46 \\
\hline $13 R-1,21-26$ & 108.7 & 124 & 20 & 49 & 27 & 36 & 54 & 46 & 63 & 24 & 27 & 29 & 52 \\
\hline $14 \mathrm{R}-1,26-28$ & 118.5 & 147 & 20 & 30 & 37 & 30 & 40 & 46 & 44 & 21 & 20 & 12 & 37 \\
\hline $15 \mathrm{R}-1,24-26$ & 128.1 & 97 & 41 & 40 & 36 & 35 & 133 & 51 & 96 & 22 & 27 & 30 & 49 \\
\hline $16 \mathrm{R}-1,135-138$ & 139.0 & 477 & 69 & 44 & 40 & 55 & 238 & 39 & 129 & 18 & 23 & 30 & 56 \\
\hline $17 \mathrm{R}-1,28-30$ & 147.5 & 172 & 29 & 44 & 35 & 44 & 110 & 37 & 78 & 16 & 20 & 27 & 50 \\
\hline $18 \mathrm{R}-2,14-17$ & 158.6 & 484 & 47 & 40 & 34 & 66 & 116 & 38 & 83 & 16 & 13 & 23 & 46 \\
\hline 19R-CC, $12-16$ & 176.3 & 173 & 25 & 18 & 24 & 26 & 74 & 26 & 59 & 17 & 17 & 23 & 36 \\
\hline $20 \mathrm{R}-1,8-12$ & 176.5 & 94 & 20 & 17 & 15 & 12 & 38 & 20 & 45 & 12 & 13 & 16 & 26 \\
\hline \multicolumn{14}{|l|}{ 129-801B. } \\
\hline $8 R-2,60-63$ & 254.8 & 36 & 20 & 21 & 14 & 11 & 42 & 25 & 39 & 14 & 16 & 16 & 20 \\
\hline $10 \mathrm{R}-1,70-73$ & 272.7 & 85 & 304 & 106 & 175 & 41 & 259 & 123 & 156 & 18 & 24 & 44 & 34 \\
\hline $11 R-1,31-36$ & 282.0 & 127 & 25 & 54 & 37 & 30 & 170 & 81 & 81 & 16 & 12 & 29 & 55 \\
\hline $12 \mathrm{R}-1,64-70$ & 292.0 & 41 & 23 & 27 & 22 & 48 & 48 & 34 & 57 & 26 & 14 & 22 & 36 \\
\hline $14 \mathrm{R}-1,52-57$ & 310.8 & 191 & 20 & 40 & 33 & 28 & 58 & 58 & 49 & 13 & 10 & 22 & 42 \\
\hline $15 \mathrm{R}-1,19-20$ & 319.9 & 534 & 20 & 38 & 34 & 44 & 135 & 51 & 61 & 13 & 10 & 23 & 42 \\
\hline $16 \mathrm{R}-1,40-43$ & 329.6 & 151 & 20 & 13 & 10 & 10 & 17 & 26 & 22 & 7 & 10 & 10 & 23 \\
\hline $17 \mathrm{R}-1,34-36$ & 338.9 & 325 & 20 & 17 & 15 & 10 & 22 & 32 & 25 & 9 & 10 & 10 & 26 \\
\hline $18 \mathrm{R}-1,37-40$ & 348.2 & 205 & 20 & 27 & 15 & 10 & 26 & 34 & 29 & 12 & 10 & 10 & 21 \\
\hline $19 \mathrm{R}-1,24-26$ & 357.5 & 78 & 20 & 10 & 10 & 10 & 10 & 21 & 14 & 5 & 10 & 10 & 29 \\
\hline $20 \mathrm{R}-1,23-26$ & 366.7 & 503 & 20 & 34 & 11 & 14 & 27 & 29 & 31 & 8 & 10 & 13 & 23 \\
\hline $21 \mathrm{R}-1,12-13$ & 375.8 & 672 & 20 & 53 & 14 & 10 & 28 & 28 & 29 & 8 & 10 & 10 & 12 \\
\hline $24 \mathrm{R}-1,69-73$ & 393.3 & 603 & 20 & 50 & 14 & 21 & 29 & 27 & 36 & 9 & 10 & 16 & 24 \\
\hline $25 \mathrm{R}-1,49-53$ & 397.7 & 1020 & 20 & 80 & 22 & 47 & 59 & 37 & 53 & 13 & 10 & 15 & 28 \\
\hline 26R-CC, $0-4$ & 407.0 & 1690 & 20 & 120 & 18 & 45 & 58 & 47 & 52 & 10 & 10 & 20 & 37 \\
\hline $27 \mathrm{R}-1,104-107$ & 407.7 & 251 & 20 & 55 & 10 & 10 & 10 & 23 & 19 & 5 & 10 & 10 & 16 \\
\hline $29 \mathrm{R}-1,17-19$ & 416.4 & 395 & 20 & 58 & 10 & 10 & 16 & 27 & 26 & 7 & 10 & 12 & 18 \\
\hline $31 \mathrm{R}-1,18-20$ & 425.8 & 369 & 20 & 40 & 10 & 12 & 15 & 26 & 29 & 5 & 10 & 10 & 17 \\
\hline $33 \mathrm{R}-1,10-14$ & 434.9 & 4000 & 40 & 154 & 62 & 73 & 159 & 98 & 124 & 23 & 10 & 13 & 58 \\
\hline $33 \mathrm{R}-1,126-129$ & 436.1 & 1010 & 37 & 55 & 25 & 41 & 37 & 45 & 60 & 5 & 10 & 14 & 36 \\
\hline $35 \mathrm{R}-1,051-055$ & 444.8 & 4000 & 51 & 106 & 69 & 93 & 137 & 114 & 125 & 12 & 10 & 24 & 61 \\
\hline $35 \mathrm{R}-1,123-127$ & 445.5 & 978 & 30 & 87 & 59 & 59 & 48 & 85 & 94 & 11 & 13 & 20 & 63 \\
\hline $37 \mathrm{R}-1,7-10$ & 453.6 & 24 & 20 & 24 & 20 & 10 & 10 & 32 & 26 & 5 & 10 & 10 & 20 \\
\hline $39 \mathrm{R}-1,4-7$ & 462.7 & 279 & 20 & 17 & 14 & 10 & 10 & 19 & 18 & 6 & 10 & 10 & 6.3 \\
\hline \multicolumn{14}{|l|}{$129-801 C$} \\
\hline $4 \mathrm{R}-1,11-16$ & 521.8 & 18 & 20 & 10 & 20 & 10 & 10 & 17 & 13 & 5 & 10 & 10 & 35 \\
\hline $5 R-4,11-16$ & 535.8 & 21 & 20 & 10 & 37 & 10 & 120 & 12 & 16 & 5 & 10 & 10 & 1 \\
\hline $6 \mathrm{R}-1,31-34$ & 540.8 & 21 & 20 & 10 & 45 & 10 & 124 & 33 & 15 & 11 & 10 & 10 & 1 \\
\hline
\end{tabular}

Note: Analyses obtained by X-ray spectroscopy, and by mass spectrometer for B, U.S. Geological Survey laboratories.

Table B3. Minor element analyses (in parts per million) for samples from Site 802, Leg 129.

\begin{tabular}{lrrrrrrrrrrrrr}
\hline \multicolumn{1}{c}{ Sample (cm) } & $\begin{array}{l}\text { Depth } \\
\text { (mbsf) }\end{array}$ & $\mathrm{Ba}$ & $\mathrm{Cr}$ & $\mathrm{Cu}$ & $\mathrm{Ni}$ & $\mathrm{Rb}$ & $\mathrm{Sr}$ & $\mathrm{Zn}$ & $\mathrm{Zr}$ & $\mathrm{Y}$ & $\mathrm{La}$ & $\mathrm{Ce}$ & $\mathrm{B}$ \\
\hline 129-802A- & & & & & & & & & & & & & \\
& & & & & & & & & & & & & \\
33R-1, 116-120 & 294.0 & 1020 & 20 & 37 & 22 & 10 & 505 & 25 & 28 & 16 & 10 & 10 & 20 \\
34R-1, 128-132 & 303.6 & 19 & 20 & 10 & 14 & 10 & 10 & 27 & 10 & 5 & 10 & 10 & 49 \\
35R-CC, 0-4 & 320.5 & 32 & 20 & 11 & 16 & 10 & 10 & 28 & 11 & 5 & 10 & 10 & 35 \\
37R-1, 11-15 & 330.0 & 26 & 25 & 18 & 16 & 10 & 56 & 25 & 20 & 14 & 10 & 10 & 75 \\
38R-CC, 12-15 & 348.6 & 111 & 61 & 44 & 88 & 21 & 240 & 90 & 131 & 31 & 28 & 32 & 64 \\
39R-1, 10-15 & 348.8 & 60 & 45 & 53 & 50 & 17 & 245 & 72 & 102 & 28 & 23 & 28 & 55 \\
43R-1, 75-78 & 382.9 & 79 & 30 & 26 & 32 & 42 & 80 & 37 & 61 & 44 & 39 & 55 & 59 \\
52R-2, 125-130 & 462.6 & 115 & 30 & 59 & 54 & 49 & 153 & 86 & 96 & 49 & 49 & 57 & 78 \\
55R-1, 138-141 & 489.3 & 116 & 21 & 104 & 81 & 43 & 102 & 98 & 92 & 45 & 32 & 45 & 36 \\
56R-1, 43-47 & 497.5 & 132 & 24 & 77 & 82 & 44 & 254 & 107 & 121 & 33 & 26 & 33 & 47 \\
56R-2, 88-92 & 499.5 & 56 & 20 & 18 & 46 & 36 & 39 & 48 & 49 & 40 & 26 & 34 & 80 \\
\hline
\end{tabular}

Note: Analyses obtained by X-ray spectroscopy, and by mass spectrometer for B, U.S. Geological Survey laboratories. 
APPENDIX C

Table C1. Rare earth element and minor element analyses (in parts per million) for samples from Site 800, Leg 129.

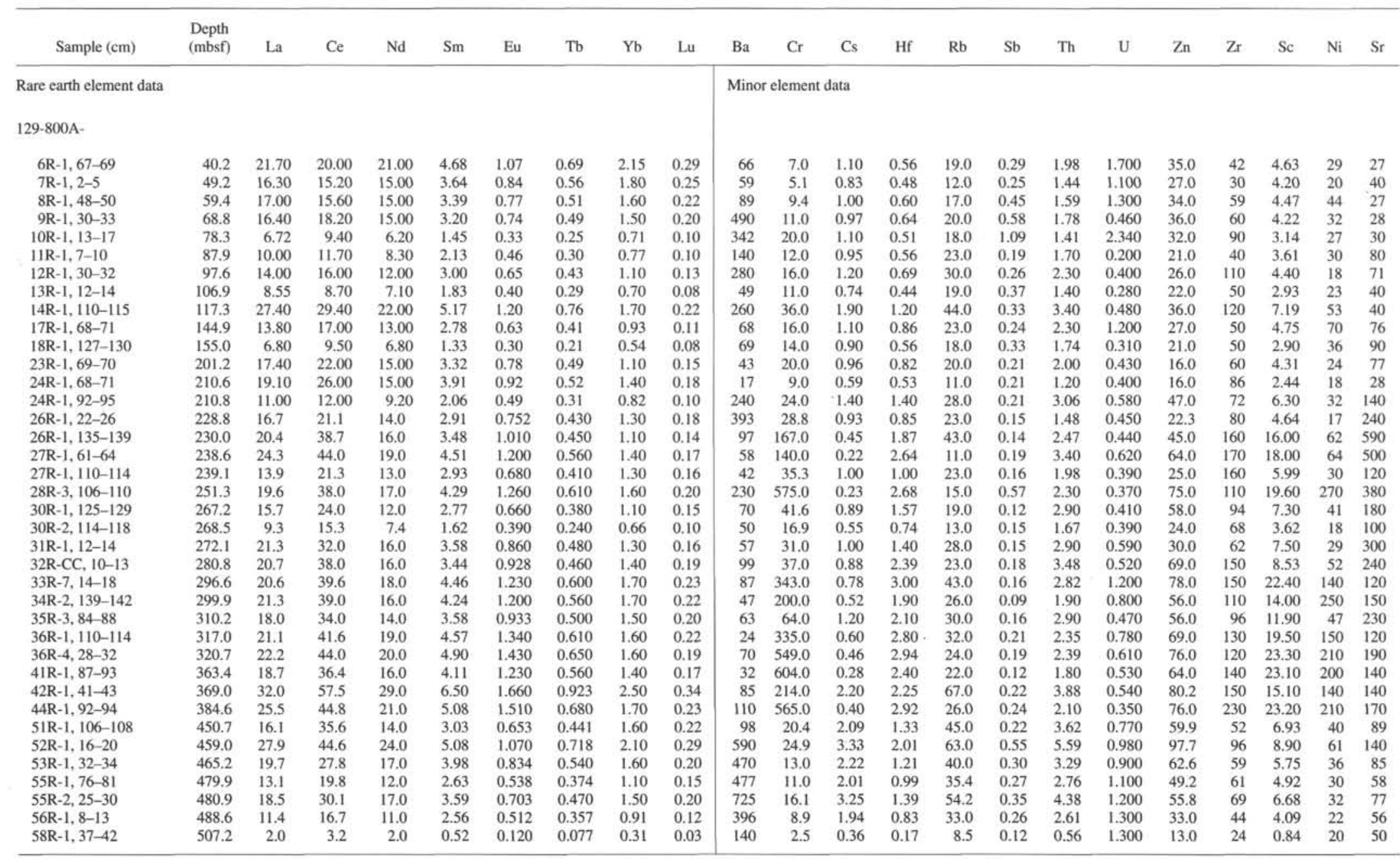

Note: Analyses obtained by induced neutron activation analysis (INAA), U.S. Geological Survey laboratories. 
Table C2. Rare earth element and minor element analyses (in parts per million) for samples from Site 801, Leg 129.

\begin{tabular}{|c|c|c|c|c|c|c|c|c|c|c|c|c|c|c|c|c|c|c|c|c|c|c|}
\hline Sample (cm) & $\begin{array}{c}\text { Depth } \\
\text { (mbsf) }\end{array}$ & $\mathrm{La}$ & $\mathrm{Ce}$ & $\mathrm{Nd}$ & $\mathrm{Sm}$ & Eu & $\mathrm{Tb}$ & $\mathrm{Yb}$ & Lu & $\mathrm{Ba}$ & $\mathrm{Cr}$ & Cs & $\mathrm{Hf}$ & $\mathrm{Rb}$ & $\mathrm{Sb}$ & Th & $\mathrm{U}$ & $\mathrm{Zn}$ & $\mathrm{Zr}$ & $\mathrm{Sc}$ & $\mathrm{Ni}$ & $\mathrm{Sr}$ \\
\hline Rare earth element data & & & & & & & & & & Minor e & ment data & & & & & & & & & & & \\
\hline \multicolumn{23}{|l|}{$129-801 \mathrm{~A}-$} \\
\hline $8 \mathrm{R}-1,1-3$ & 60.6 & 2.7 & 2.9 & 3.2 & 0.70 & 0.140 & 0.098 & 0.40 & 0.02 & 180 & 2.00 & 0.2 & 0.17 & 4.3 & 0.14 & 0.39 & 0.60 & 18.0 & 40 & 0.608 & 11 & 40 \\
\hline $9 \mathrm{R}-1,0-3$ & 70.2 & 22.2 & 26.0 & 20.0 & 4.89 & 1.060 & 0.720 & 2.15 & 0.29 & 57 & 9.88 & 1.6 & 0.77 & 26.0 & 0.33 & 2.60 & 1.80 & 36.0 & 39 & 5.230 & 32 & 33 \\
\hline $10 \mathrm{R}-1,0-5$ & 79.5 & 10.5 & 11.9 & 9.7 & 2,43 & 0.557 & 0.360 & 1.10 & 0.16 & 39 & 5.70 & 0.72 & 0.45 & 11.0 & 0.24 & 1.08 & 2.00 & 21.0 & 28 & 2.840 & 11 & 19 \\
\hline $12 \mathrm{R}-1,22-25$ & 99.0 & 16.7 & 32.3 & 13.0 & 2.83 & 0.704 & 0.341 & 0.90 & 0.12 & 180 & 15.40 & 0.97 & 2.05 & 25.0 & 0.24 & 2.89 & 0.44 & 50.4 & 80 & 6.310 & 27 & 90 \\
\hline $80-100 \mathrm{M}$ & 100.0 & 18.1 & 19.8 & 16.0 & 3.94 & 0.854 & 0.553 & 1.68 & 0.22 & 97 & 11.40 & 1.23 & 0.89 & 25.0 & 0.29 & 2.37 & 0.46 & 39.5 & 50 & 4.570 & 21 & 26 \\
\hline $13 \mathrm{R}-1,21-26$ & 108.7 & 16.9 & 25.5 & 16.0 & 3.66 & 0.801 & 0.505 & 1.30 & 0.17 & 110 & 12.20 & 1.17 & 0.93 & 25.0 & 0.16 & 2.67 & 0.39 & 35.0 & 43 & 4.490 & 25 & 36 \\
\hline $14 \mathrm{R}-1,26-28$ & 118.5 & 14.2 & 14.7 & 14.0 & 3.18 & 0.695 & 0.474 & 1.30 & 0.18 & 130 & 14.50 & 1.11 & 0.66 & 25.0 & 0.27 & 2.16 & 0.35 & 33.3 & 50 & 3.920 & 31 & 34 \\
\hline $15 \mathrm{R}-1,24-26$ & 128.1 & 18.7 & 28.3 & 16.0 & 3.59 & 0.876 & 0.520 & 1.20 & 0.17 & 81 & 37.10 & 0.97 & 1.45 & 23.0 & 0.24 & 2.68 & 0.31 & 36.0 & 79 & 5.420 & 32 & 97 \\
\hline $16 \mathrm{R}-1,135-138$ & 139.0 & 18.3 & 30.9 & 17.0 & 3.68 & 0.909 & 0.473 & 0.92 & 0.12 & 430 & 52.90 & 1.1 & 1.95 & 33.0 & 0.18 & 3.04 & 0.39 & 27.0 & 81 & 6.450 & 33 & 140 \\
\hline $17 \mathrm{R}-1,28-30$ & 147.5 & 14.4 & 24.1 & 13.0 & 2.98 & 0.727 & 0.400 & 0.96 & 0.12 & 160 & 29.40 & 1.3 & 1.21 & 32.0 & 0.17 & 2.57 & 0.34 & 29.0 & 49 & 5.350 & 24 & 95 \\
\hline $18 \mathrm{R}-2,14-17$ & 158.6 & 14.1 & 24.0 & 12.0 & 2,72 & 0.649 & 0.370 & 0.98 & 0.13 & 443 & 38.40 & 1.53 & 1.32 & 41.2 & 0.19 & 3.10 & 0.29 & 29.0 & 44 & 5.560 & 29 & 76 \\
\hline 19R-CC, $12-16$ & 176.3 & 12.0 & 20.5 & 11.0 & 2.64 & 0.650 & 0.358 & 0.81 & 0.11 & 160 & 28.30 & 0.84 & 0.92 & 20.0 & 0.19 & 1.74 & 0.25 & 18.0 & 60 & 3.480 & 20 & 40 \\
\hline $20 \mathrm{R}-1,8-12$ & 176.5 & 9.8 & 15.0 & 8.2 & 1.84 & 0.449 & 0.280 & 0.66 & 0.08 & 89 & 23.00 & 0.49 & 0.69 & 14.0 & 0.10 & 1.26 & 0.20 & 14.0 & 57 & 2.400 & 11 & 39 \\
\hline \multicolumn{23}{|l|}{ 129-801B- } \\
\hline $8 R-2,60-63$ & 254.8 & 12.0 & 16.5 & 8.1 & 1.94 & 0.453 & 0.301 & 0.79 & 0.10 & 21 & 16.30 & 0.58 & 0.59 & 12.0 & 0.16 & 1.11 & 0.39 & 15.0 & 50 & 2.400 & 12 & 34 \\
\hline $10 \mathrm{R}-1,70-73$ & 272.7 & 17.7 & 35.7 & 18.0 & 4.22 & 1.210 & 0.553 & 1.30 & 0.17 & 73 & 213.00 & 0.67 & 2.98 & 35.0 & 0.17 & 1.97 & 1.50 & 103.0 & 120 & 15.100 & 150 & 220 \\
\hline IIR-1, 31-36 & 282.0 & 12.00 & 26.40 & 11.0 & 2.760 & 0.661 & 0.412 & 1.20 & 0.150 & 120 & 29.6 & 2.12 & 1.500 & 31.00 & 0.24 & 2.50 & 0.80 & 64.0 & 70 & 8.39 & 33.0 & 150.0 \\
\hline $12 \mathrm{R}-1,64-70$ & 292.0 & 10.20 & 20.20 & 10.0 & 2.820 & 0.756 & 0.510 & 2.02 & 0.286 & 35 & 33.3 & 1.10 & 1.060 & 48.20 & 0.20 & 1.56 & 0.25 & 26.0 & 43 & 5.80 & 16.0 & 44,0 \\
\hline $14 \mathrm{R}-1,52-57$ & 310.8 & 10.50 & 18.10 & 8.8 & 1.980 & 0.389 & 0.280 & 0.87 & 0.130 & 200 & 11.5 & 1.77 & 0.869 & 30.00 & 0.18 & 2.63 & 0.76 & 43.3 & 58 & 4.41 & 29.0 & 51.0 \\
\hline $15 \mathrm{R}-1,19-20$ & 319.9 & 11.70 & 25.30 & 10.0 & 2.100 & 0.408 & 0.290 & 1.10 & 0.140 & 532 & 12.7 & 2.16 & 1.070 & 33.00 & 0.29 & 3.25 & 0.74 & 37.0 & 90 & 5.48 & 34.0 & 100.0 \\
\hline $16 \mathrm{R}-1,40-43$ & 329.6 & 4.80 & 6.55 & 4.3 & 1.140 & 0.220 & 0.140 & 0.41 & 0.057 & 130 & 3.9 & 0.73 & 0.330 & 12.00 & 0.09 & 1.05 & 2.50 & 15.0 & 50 & 1.80 & 11.0 & 22.0 \\
\hline $17 \mathrm{R}-1,34-36$ & 338.9 & 7.10 & 8.31 & 7.8 & 1.870 & 0.403 & 0.270 & 0.66 & 0.087 & 330 & 3.9 & 0.87 & 0.420 & 14.00 & 0.24 & 1.23 & 1.20 & 17.0 & 57 & 2.15 & 22.0 & 28.0 \\
\hline $18 \mathrm{R}-1,37-40$ & 348.2 & 8.76 & 9.94 & 8.1 & 1.800 & 0.387 & 0.288 & 0.79 & 0.097 & 200 & 5.9 & 0.93 & 0.470 & 15.00 & 0.20 & 1.49 & 1.70 & 22.0 & 40 & 2.37 & 12.0 & 30.0 \\
\hline $19 \mathrm{R}-1,24-26$ & 357.5 & 1.80 & 3.30 & 1.9 & 0.420 & 0.096 & 0.070 & 0.29 & 0.021 & 67 & 2.5 & 0.28 & 0.200 & 4.00 & 0.12 & 0.47 & 2.90 & 11.0 & 40 & 0.91 & 12.0 & 30.0 \\
\hline $20 \mathrm{R}-1,23-26$ & 366.7 & 4.70 & 8.73 & 4.8 & 1.150 & 0.250 & 0.170 & 0.57 & 0.068 & 510 & 5.2 & 1.20 & 0.480 & 17.00 & 0.25 & 1.37 & 1.70 & 17.0 & 39 & 2.57 & 18.0 & 32.0 \\
\hline $21 \mathrm{R}-1,12-13$ & 375.8 & 6.20 & 7.19 & 5.6 & 1.390 & 0.300 & 0.210 & 0.83 & 0.090 & 684 & 4.4 & 0.86 & 0.430 & 14.00 & 0.23 & 1.25 & 0.54 & 19.0 & 48 & 2.36 & 16.0 & 28.0 \\
\hline $24 \mathrm{R}-1,69-73$ & 393.3 & 6.40 & 11.50 & 6.5 & 1.450 & 0.295 & 0.210 & 0.71 & 0.100 & 580 & 6.0 & 1.64 & 0.600 & 24.00 & 0.22 & 1.70 & 0.54 & 20.0 & 37 & 3.25 & 8.9 & 25.0 \\
\hline $25 \mathrm{R}-1,49-53$ & 397.7 & 10.90 & 16.70 & 10.0 & 2.170 & 0.436 & 0.304 & 1.06 & 0.151 & 958 & 11.9 & 2.58 & 0.952 & 43.00 & 0.53 & 2.95 & 0.52 & 29.4 & 39 & 4.82 & 15.0 & 55.0 \\
\hline 26R-CC, $0-4$ & 407.0 & 10.50 & 15.90 & 9.8 & 2.150 & 0.438 & 0.307 & 1.00 & 0.150 & 1500 & 11.1 & 2.57 & 0.940 & 42.00 & 0.56 & 2.82 & 0.94 & 32.0 & 55 & 5.16 & 15.0 & 60.0 \\
\hline $27 \mathrm{R}-1,104-107$ & 407.7 & 3.60 & 6.01 & 3.5 & 0.793 & 0.170 & 0.130 & 0.37 & 0.046 & 240 & 3.5 & 0.77 & 0.320 & 12.00 & 0.35 & 0.92 & 1.50 & 8.8 & 42 & 1.77 & 8.0 & 23.0 \\
\hline $29 \mathrm{R}-1,17-19$ & 416.4 & 7.34 & 9.60 & 6.4 & 1.480 & 0.308 & 0.210 & 0.77 & 0.096 & 360 & 4.0 & 1.10 & 0.450 & 16.00 & 0.27 & 1.19 & 0.83 & 15.0 & 4 & 2.36 & 12.0 & 30.0 \\
\hline $31 \mathrm{R}-1,18-20$ & 425.8 & 5.00 & 6.68 & 4.1 & 1.040 & 0.210 & 0.150 & 0.50 & 0.074 & 330 & 4.5 & 1.07 & 0.490 & 18.00 & 0.20 & 1.18 & 0.68 & 15.0 & 25 & 2.32 & 8.3 & 22.0 \\
\hline $33 \mathrm{R}-1,10-14$ & 434.9 & 19.60 & 28.00 & 27.0 & 5.940 & 1.370 & 0.915 & 2.24 & 0.323 & 6190 & 27.2 & 4.81 & 3.050 & 78.00 & 1.30 & 4.60 & 1.10 & 77.9 & 100 & 15.40 & 65.0 & 180.0 \\
\hline $33 \mathrm{R}-1,126-129$ & 436.1 & 8.09 & 10.00 & 6.8 & 1.420 & 0.300 & 0.200 & 0.66 & 0.095 & 917 & 28.9 & 3.05 & 1.400 & 46.80 & 0.48 & 2.55 & 1.00 & 34.4 & 60 & 6.56 & 24.0 & 39.0 \\
\hline $35 \mathrm{R}-1,51-55$ & 444.8 & 25.60 & 29.90 & 22.0 & 3.830 & 0.773 & 0.460 & 1.30 & 0.200 & 4000 & 39.3 & 5.30 & 3.200 & 94.70 & 0.99 & 5.38 & 0.98 & 92.1 & 110 & 14.70 & 61.0 & 150.0 \\
\hline $35 \mathrm{R}-1,123-127$ & 445.5 & 11.60 & 14.50 & 10.0 & 2.300 & 0.516 & 0.360 & 1.20 & 0.170 & 894 & 22.9 & 3.38 & 2.170 & 59.00 & 1.40 & 2.98 & 0.90 & 63.5 & 130 & 10.50 & 52.0 & 40.0 \\
\hline $37 \mathrm{R}-1,7-10$ & 453.6 & 1.80 & 2.30 & 1.4 & 0.440 & 0.110 & 0.065 & 0.23 & 0.035 & 20 & 2.9 & 0.56 & 0.650 & 13.00 & 0.21 & 0.38 & 0.46 & 17.0 & 29 & 2.76 & 17.0 & 0.0052 \\
\hline $39 \mathrm{R}-1,4-7$ & 462.7 & 4.90 & 3.90 & 5.0 & 1.110 & 0.270 & 0.200 & 0.65 & 0.080 & 250 & 5.3 & 0.31 & 0.380 & 7.60 & 0.10 & 0.58 & 0.23 & 7.5 & 27 & 2.11 & 22.0 & 24.0 \\
\hline \multicolumn{23}{|l|}{$129-801 \mathrm{C}-$} \\
\hline $4 \mathrm{R}-1,11-16$ & 521.8 & 0.77 & 0.22 & 0.6 & 0.130 & 0.047 & 0.051 & 0.28 & 0.022 & 17 & 3.6 & 0.09 & 0.096 & 3.10 & 0.31 & 0.08 & 0.21 & 13.0 & 40 & 0.50 & 22.0 & 40.0 \\
\hline $5 R-4,11-16$ & 535.8 & 1.90 & 1.60 & 1.8 & 0.460 & 0.120 & 0.083 & 0.28 & 0.040 & 9.9 & 3.4 & 0.16 & 0.110 & 9.30 & 0.05 & 0.16 & 0.30 & 7.3 & 17 & 0.98 & 15.0 & 130.0 \\
\hline $6 \mathrm{R}-1,31-34$ & 540.8 & 1.60 & 2.20 & 2.4 & 0.868 & 0.260 & 0.230 & 1.10 & 0.150 & 12 & 21.6 & 0.07 & 0.140 & 2.00 & 0.04 & 0.11 & 0.44 & 34.0 & 30 & 7.32 & 32.0 & 140.0 \\
\hline
\end{tabular}

Note: Analyses obtained by induced neutron activation analysis (INAA), U.S. Geological Survey laboratories. 
Table C3. Rare earth element and minor element analyses (in parts per million) for samples from Site 802, Leg 129.

\begin{tabular}{|c|c|c|c|c|c|c|c|c|c|c|c|c|c|c|}
\hline Sample (cm) & $\begin{array}{l}\text { Dept } \\
\text { (mbs }\end{array}$ & & $\mathrm{La}$ & $\mathrm{Ce}$ & $\mathrm{Nd}$ & $\mathrm{Sm}$ & $\mathrm{Eu}$ & $\mathrm{Tb}$ & $\mathrm{Yb}$ & $\mathrm{Lu}$ & & & & \\
\hline \multicolumn{15}{|c|}{ Rare earth element data } \\
\hline \multicolumn{15}{|l|}{$129-802 \mathrm{~A}-$} \\
\hline $33 \mathrm{R}-1,116-120$ & 294. & & 12.20 & 7.92 & 12.0 & 2.590 & 0.598 & 0.385 & 1.23 & 0.170 & & & & \\
\hline $34 \mathrm{R}-1,128-132$ & 303. & & 4.70 & 2.10 & 4.5 & 1.030 & 0.255 & 0.182 & 0.54 & 0.067 & & & & \\
\hline $35 \mathrm{R}-\mathrm{CC}, 0-4$ & 320. & & 4.70 & 3.50 & 4.4 & 1.060 & 0.230 & 0.170 & 0.51 & 0.048 & & & & \\
\hline $37 \mathrm{R}-1,11-15$ & 330. & & 11.00 & 6.91 & 9.4 & 2.190 & 0.489 & 0.340 & 0.95 & 0.130 & & & & \\
\hline $38 \mathrm{R}-\mathrm{CC}, 12-15$ & 348. & & 29.10 & 34.80 & 28.0 & 6.800 & 1.670 & 0.977 & 2.59 & 0.346 & & & & \\
\hline $39 \mathrm{R}-1,10-15$ & 348. & & 24.80 & 24.20 & 23.0 & 5.640 & 1.300 & 0.764 & 2.15 & 0.303 & & & & \\
\hline $43 \mathrm{R}-1,75-78$ & 382. & & 34.30 & 48.40 & 29.0 & 6.970 & 1.650 & 1.070 & 2.64 & 0.350 & & & & \\
\hline $52 \mathrm{R}-2,125-130$ & 462. & & 43.00 & 52.80 & 36.0 & 8.710 & 1.980 & 1.280 & 3.51 & 0.480 & & & & \\
\hline $55 R-1,138-141$ & 489. & & 32.00 & 40.00 & 26.0 & 6.140 & 1.430 & 0.983 & 3.18 & 0.438 & & & & \\
\hline $56 \mathrm{R}-1,43-47$ & 497. & & 27.00 & 35.00 & 25.0 & 5.870 & 1.400 & 0.840 & 2.43 & 0.344 & & & & \\
\hline $56 \mathrm{R}-2,88-92$ & 499 & & 20.70 & 28.80 & 22.0 & 5.900 & 1.550 & 0.980 & 3.12 & 0.429 & & & & \\
\hline Sample (cm) & $\begin{array}{l}\text { Depth } \\
\text { (mbsf) }\end{array}$ & $\mathrm{Ba}$ & $\mathrm{Cr}$ & Cs & $\mathrm{Hf}$ & $\mathrm{Rb}$ & $\mathrm{Sb}$ & Th & $\mathbf{U}$ & $\mathrm{Zn}$ & $\mathrm{Zr}$ & $\mathrm{Sc}$ & $\mathrm{Ni}$ & $\mathrm{Sr}$ \\
\hline \multicolumn{15}{|l|}{ Minor element data } \\
\hline \multicolumn{15}{|l|}{$129-802 \mathrm{~A}$ - } \\
\hline $33 \mathrm{R}-1,116-120$ & 294.0 & 897 & 3.5 & 0.23 & 0.330 & 4.30 & 0.10 & 0.56 & 0.19 & 17.0 & 25 & 2.48 & 19.0 & 480.0 \\
\hline $34 \mathrm{R}-1,128-132$ & 303.6 & 13 & 2.1 & 0.09 & 0.140 & 3.10 & 0.16 & 0.19 & 0.54 & 7.4 & 30 & 0.67 & 12.0 & 40.0 \\
\hline $35 \mathrm{R}-\mathrm{CC}, 0-4$ & 320.5 & 18 & 1.9 & 0.20 & 0.190 & 4.20 & 0.12 & 0.30 & 1.90 & 21.0 & 18 & 1.12 & 11.0 & 40.0 \\
\hline $37 \mathrm{R}-1,11-15$ & 330.0 & 27 & 11.7 & 0.30 & 0.290 & 5.00 & 0.15 & 0.76 & 1.60 & 13.0 & 40 & 1.77 & 8.0 & 41.0 \\
\hline $38 \mathrm{R}-\mathrm{CC}, 12-15$ & 348.6 & 100 & 51.4 & 0.95 & 2.600 & 25.00 & 0.34 & 3.23 & 0.62 & 68.1 & 120 & 8.73 & 71.0 & 230.0 \\
\hline $39 \mathrm{R}-1,10-15$ & 348.8 & 54 & 36.9 & 0.61 & 1.780 & 15.00 & 0.24 & 2.14 & 0.47 & 55.3 & 60 & 7.08 & 39.0 & 200.0 \\
\hline $43 \mathrm{R}-1,75-78$ & 382.9 & 72 & 21.2 & 2.02 & 1.140 & 40.20 & 0.20 & 3.14 & 0.83 & 30.0 & 52 & 6.31 & 26.0 & 71.0 \\
\hline $52 \mathrm{R}-2,125-130$ & 462.6 & 100 & 24.0 & 2.97 & 1.870 & 47.80 & 0.22 & 4.76 & 0.93 & 65.5 & 96 & 10.10 & 47.0 & 160.0 \\
\hline $55 \mathrm{R}-1,138-141$ & 489.3 & 99 & 21.8 & 2.13 & 1.720 & 40.00 & 0.30 & 4.08 & 0.66 & 72.3 & 87 & 8.61 & 69.0 & 100.0 \\
\hline $56 \mathrm{R}-1,43-47$ & 497.5 & 110 & 26.6 & 1.92 & 2.310 & 39.00 & 0.23 & 4.01 & 0.82 & 86.6 & 110 & 11.40 & 74.0 & 230.0 \\
\hline $56 \mathrm{R}-2,88-92$ & 499.5 & 45 & 12.1 & 1.54 & 0.930 & 41.00 & 0.19 & 2.29 & 0.48 & 37.0 & 33 & 6.90 & 34.0 & 50.0 \\
\hline
\end{tabular}

Note: Analyses obtained by induced neutron activation analysis (INAA), U.S. Geological Survey laboratories. 
[BLANK PAGE] 
APPENDIX D

Table D1. Major element oxide data (in percent) for additional samples from Leg 129.

\begin{tabular}{|c|c|c|c|c|c|c|c|c|c|c|c|c|c|}
\hline Sample $(\mathrm{cm})$ & $\begin{array}{l}\text { Depth } \\
\text { (mbsf) }\end{array}$ & Unit & $\mathrm{SiO}_{2}$ & $\mathrm{Al}_{2} \mathrm{O}_{3}$ & $\mathrm{FeTO}_{3}$ & $\mathrm{MgO}$ & $\mathrm{CaO}$ & $\mathrm{Na}_{2} \mathrm{O}$ & $\mathrm{K}_{2} \mathrm{O}$ & $\mathrm{TiO}_{2}$ & $\mathrm{Mn}_{3} \mathrm{O}_{4}$ & $\begin{array}{c}\text { LOI } \\
925 \mathrm{C}\end{array}$ & $\begin{array}{l}\text { Oxide } \\
\text { total }\end{array}$ \\
\hline \multicolumn{14}{|l|}{$129-800 \mathrm{~A}-$} \\
\hline $6 \mathrm{R}-1.7$ & 39.7 & II & 85.50 & 4.40 & 2.00 & 1.04 & 0.40 & 1.00 & 1.07 & 0.20 & 0.27 & 4.30 & 100.18 \\
\hline $6 \mathrm{R}-1,37$ & 40.0 & II & 80.80 & 5.30 & 2.50 & 1.36 & 0.70 & 1.14 & 1.38 & 0.23 & 0.44 & 5.54 & 99.39 \\
\hline $7 R-1.66$ & 49.8 & II & 92.00 & 1.50 & 1.00 & 0.42 & 0.20 & 0.39 & 0.44 & 0.13 & 0.20 & 2.74 & 99.02 \\
\hline $8 \mathrm{R}-1.1$ & 58.9 & II & 87.50 & 2.90 & 1.50 & 0.90 & 0.90 & 0.70 & 0.66 & 0.15 & 0.22 & 3.90 & 99.33 \\
\hline $8 \mathrm{R}-1,22$ & 59.1 & II & 89.00 & 2.50 & 1.30 & 0.83 & 0.20 & 0.70 & 0.69 & 0.14 & 0.11 & 3.50 & 98.97 \\
\hline $10 \mathrm{R}-1,13$ & 78.3 & III & 92.80 & 1.50 & 1.70 & 0.33 & 0.20 & 0.37 & 0.48 & 0.16 & 0.01 & 2.85 & 100.40 \\
\hline $12 \mathrm{R}-1,37$ & 97.7 & III & 90.60 & 2,40 & 1.30 & 0.75 & 0.30 & 0.51 & 0.88 & 0.16 & 0.01 & 2.62 & 99,53 \\
\hline $13 R-1,46$ & 107.2 & III & 69.10 & 0.70 & 0.50 & 0.25 & 14.40 & 0.22 & 0.26 & 0.10 & 0.03 & 13.33 & 98.89 \\
\hline $14 \mathrm{R}-1,101$ & 117.2 & III & 93.00 & 1.50 & 1.10 & 0.54 & 0.30 & 0.44 & 0.57 & 0.13 & 0.01 & 2.52 & 100.11 \\
\hline $17 \mathrm{R}-1,25$ & 144.4 & III & 62.20 & 0.80 & 0.50 & 0.36 & 18.70 & 0.24 & 0.28 & 0.10 & 0.08 & 16.52 & 99.78 \\
\hline $18 \mathrm{R}-1,70$ & 154.4 & III & 83.60 & 3.90 & 2.90 & 1.28 & 0.70 & 0.92 & 1.14 & 0.37 & 0.02 & 3.63 & 98.46 \\
\hline $18 \mathrm{R}-1,12 \mathrm{I}$ & 154.9 & III & 92.00 & 1.50 & 1.10 & 0.51 & 0.30 & 0.50 & 0.50 & 0.15 & 0.01 & 2.33 & 98.90 \\
\hline $19 \mathrm{R}-1,1$ & 162.9 & III & 85.50 & 3.50 & 2.50 & 1.24 & 0.40 & 0.69 & 1.13 & 0.28 & 0.01 & 3.59 & 98.84 \\
\hline $19 \mathrm{R}-1,37$ & 163.3 & III & 80.10 & 5.50 & 4.40 & 1.90 & 0.50 & 0.97 & 1.68 & 0.46 & 0.03 & 5.00 & 100.54 \\
\hline $21 \mathrm{R}-2,8$ & 182.9 & III & 48.70 & 0.50 & 0.30 & 0.31 & 26.20 & 0.17 & 0.11 & 0.08 & 0.09 & 23.10 & 99.56 \\
\hline $22 \mathrm{R}-1,19$ & 191.2 & III & 33.60 & 6.70 & 5.20 & 2.27 & 25.00 & 1.27 & 0.84 & 1.08 & 0.07 & 24.20 & 100.23 \\
\hline $24 \mathrm{R}-1,30$ & 210.2 & III & 85.30 & 3.30 & 2.70 & 1.20 & 0.50 & 0.73 & 0.93 & 0.31 & 0.07 & 3.28 & 98.32 \\
\hline \multicolumn{14}{|l|}{$129-801 \mathrm{~A}-$} \\
\hline 7R-CC, 1 & 60.4 & II & 90.8 & 1.9 & 1.1 & 0.53 & 0.50 & 0.42 & 0.49 & 0.10 & 0.135 & 2.50 & 98.475 \\
\hline $10 \mathrm{R}-1,11$ & 79.6 & II & 90.5 & 2.1 & 1.2 & 0.54 & 0.30 & 0.55 & 0.51 & 0.16 & 0.118 & 2.68 & 98.658 \\
\hline \multicolumn{14}{|l|}{$129-801 \mathrm{~B}-$} \\
\hline $14 \mathrm{R}-1.24$ & 310.5 & IV & 82.5 & 4.8 & 3.4 & 1.42 & 0.60 & 1.19 & 1.36 & 0.30 & 0.561 & 4.51 & 100.641 \\
\hline $18 \mathrm{R}-1,24$ & 348.0 & IV & 85.4 & 3.7 & 2.4 & 0.90 & 0.50 & 0.80 & 1.15 & 0.21 & 0.303 & 3.77 & 99.133 \\
\hline $24 \mathrm{R}-1,54$ & 393.1 & IV & 85.3 & 3.2 & 2.7 & 0.97 & 0.40 & 0.80 & 0.94 & 0.17 & 0.528 & 3.21 & 98.218 \\
\hline $25 \mathrm{R}-1,1$ & 397.2 & IV & 85.9 & 3.4 & 2.8 & 0.88 & 0.60 & 0.88 & 0.99 & 0.21 & 0.428 & 3.72 & 99.808 \\
\hline $27 \mathrm{R}-1,30$ & 407.0 & IV & 96.8 & 0.3 & 0.5 & 0.06 & 0.30 & 0.19 & 0.13 & 0.05 & 0.110 & 1.60 & 100.04 \\
\hline $33 \mathrm{R}-1,43$ & 435.2 & V & 81.4 & 4.5 & 5.7 & 1.11 & 0.50 & 0.88 & 1.63 & 0.31 & 0.040 & 4.01 & 100.08 \\
\hline $33 R-2,48$ & 436.8 & V & 83.7 & 3.0 & 5.4 & 0.77 & 0.40 & 0.68 & 1.22 & 0.20 & 0.039 & 3.55 & 98.959 \\
\hline $35 \mathrm{R}-2,120$ & 447.0 & V & 56.3 & 11.3 & 15.3 & 2.84 & 1.40 & 1.43 & 3.67 & 0.85 & 0.402 & 6.85 & 100.342 \\
\hline $35 \mathrm{R}-2,140$ & 447.2 & V & 64.8 & 8.3 & 13.3 & 1.96 & 0.80 & 1.41 & 2.78 & 0.56 & 0.157 & 6.17 & 100.237 \\
\hline $35 \mathrm{R}-3,1$ & 447.3 & V & 66.7 & 8.4 & 11.1 & 2.14 & 0.70 & 1.37 & 3.06 & 0.59 & 0.149 & 5.83 & 100.039 \\
\hline $35 \mathrm{R}-3,19$ & 447.5 & V & 69.8 & 7.8 & 9.8 & 1.76 & 0.60 & 1.13 & 2.70 & 0.54 & 0.070 & 5.19 & 99.39 \\
\hline
\end{tabular}

Note: Analyses obtained by microprobe at the University of Strasbourg, France. 
Table D2. Minor element data (in parts per million) for additional samples from Leg 129.

\begin{tabular}{|c|c|c|c|c|c|c|c|c|}
\hline Sample (cm) & $\begin{array}{l}\text { Depth } \\
\text { (mbsf) }\end{array}$ & $\mathrm{Ba}$ & $\mathrm{Cr}$ & $\mathrm{Cu}$ & $\mathrm{Ni}$ & $\mathrm{Sr}$ & $\mathrm{Zn}$ & $\mathrm{Zr}$ \\
\hline \multicolumn{9}{|l|}{$129-800 \mathrm{~A}-$} \\
\hline $6 \mathrm{R}-1,7$ & 39.7 & 85 & 19 & 87 & 38 & 40 & 81 & 54 \\
\hline $6 \mathrm{R}-1,37$ & 40.0 & 150 & 19 & 138 & 44 & 59 & 98 & 60 \\
\hline $7 \mathrm{R}-1,66$ & 49.8 & 59 & 12 & 32 & 7 & 17 & 385 & 27 \\
\hline $8 \mathrm{R}-1,1$ & 58.9 & 62 & 16 & 85 & 23 & 57 & 72 & 44 \\
\hline $8 \mathrm{R}-1,22$ & 59.1 & 57 & 14 & 48 & 1 & 19 & 54 & 36 \\
\hline $10 \mathrm{R}-1,13$ & 78.3 & 214 & 31 & 42 & 5 & 16 & 42 & 29 \\
\hline $12 \mathrm{R}-1,37$ & 97.7 & 291 & 30 & 20 & 26 & 25 & 30 & 37 \\
\hline $13 \mathrm{R}-1,46$ & 107.2 & 84 & 11 & 16 & 13 & 195 & 16 & 15 \\
\hline $14 \mathrm{R}-1,101$ & 117.2 & 127 & 52 & 20 & 28 & 19 & 15 & 29 \\
\hline $17 \mathrm{R}-1,25$ & 144.4 & 324 & 13 & 12 & 16 & 194 & 16 & 19 \\
\hline $18 \mathrm{R}-1,70$ & 154.4 & 494 & 50 & 37 & 35 & 66 & 54 & 69 \\
\hline $18 \mathrm{R}-1,121$ & 154.9 & 160 & 31 & 21 & 66 & 22 & 20 & 29 \\
\hline $19 \mathrm{R}-1,1$ & 162.9 & 568 & 25 & 59 & 34 & 44 & 32 & 45 \\
\hline $19 \mathrm{R}-1,37$ & 163.3 & 714 & 43 & 81 & 37 & 71 & 56 & 76 \\
\hline $21 \mathrm{R}-2,8$ & 182.9 & 199 & 7 & 6 & 22 & 204 & 20 & 8 \\
\hline $22 \mathrm{R}-1,19$ & 191.2 & 522 & 82 & 42 & 114 & 542 & 103 & 118 \\
\hline $24 \mathrm{R}-1,30$ & 210.2 & 82 & 29 & 29 & 46 & 57 & 55 & 48 \\
\hline \multicolumn{9}{|l|}{$129-801 \mathrm{~A}-$} \\
\hline 7R-CC, 1 & 60.4 & 43 & 12 & 77 & 34 & 28 & 16 & 23 \\
\hline 10R-1, 11 & 79.6 & 100 & 9 & 42 & 23 & 26 & 32 & 14 \\
\hline \multicolumn{9}{|l|}{ 129-801B- } \\
\hline $14 \mathrm{R}-1,24$ & 310.5 & 236 & 11 & 62 & 46 & 82 & 78 & 68 \\
\hline $18 \mathrm{R}-1,24$ & 348.0 & 1059 & 16 & 64 & 30 & 56 & 51 & 53 \\
\hline $24 \mathrm{R}-1,54$ & 393.1 & 2629 & 14 & 73 & 29 & 77 & 47 & 46 \\
\hline $25 \mathrm{R}-1,1$ & 397.2 & 1544 & 8 & 69 & 18 & 72 & 66 & 49 \\
\hline $27 \mathrm{R}-1,30$ & 407.0 & 88 & 1 & 32 & 1 & 11 & 4 & 10 \\
\hline $33 \mathrm{R}-1,43$ & 435.2 & 1849 & 20 & 59 & 29 & 75 & 66 & 86 \\
\hline $33 \mathrm{R}-2,48$ & 436.8 & 923 & 16 & 94 & 29 & 42 & 39 & 73 \\
\hline $35 \mathrm{R}-2,120$ & 447.0 & 1227 & 54 & 137 & 142 & 108 & 159 & 148 \\
\hline $35 \mathrm{R}-2,140$ & 447.2 & 2560 & 39 & 119 & 82 & 114 & 124 & 155 \\
\hline $35 \mathrm{R}-3,1$ & 447.3 & 2449 & 43 & 87 & 76 & 112 & 109 & 140 \\
\hline $35 \mathrm{R}-3,19$ & 447.5 & 2036 & 13 & 62 & 60 & 92 & 104 & 112 \\
\hline
\end{tabular}

Note: Analyses obtained by microprobe at the University of Strasbourg, France. 